\title{
Geologic Map of the Rio Rico and Nogales 7.5' Quadrangles, Santa Cruz County, Arizona
}

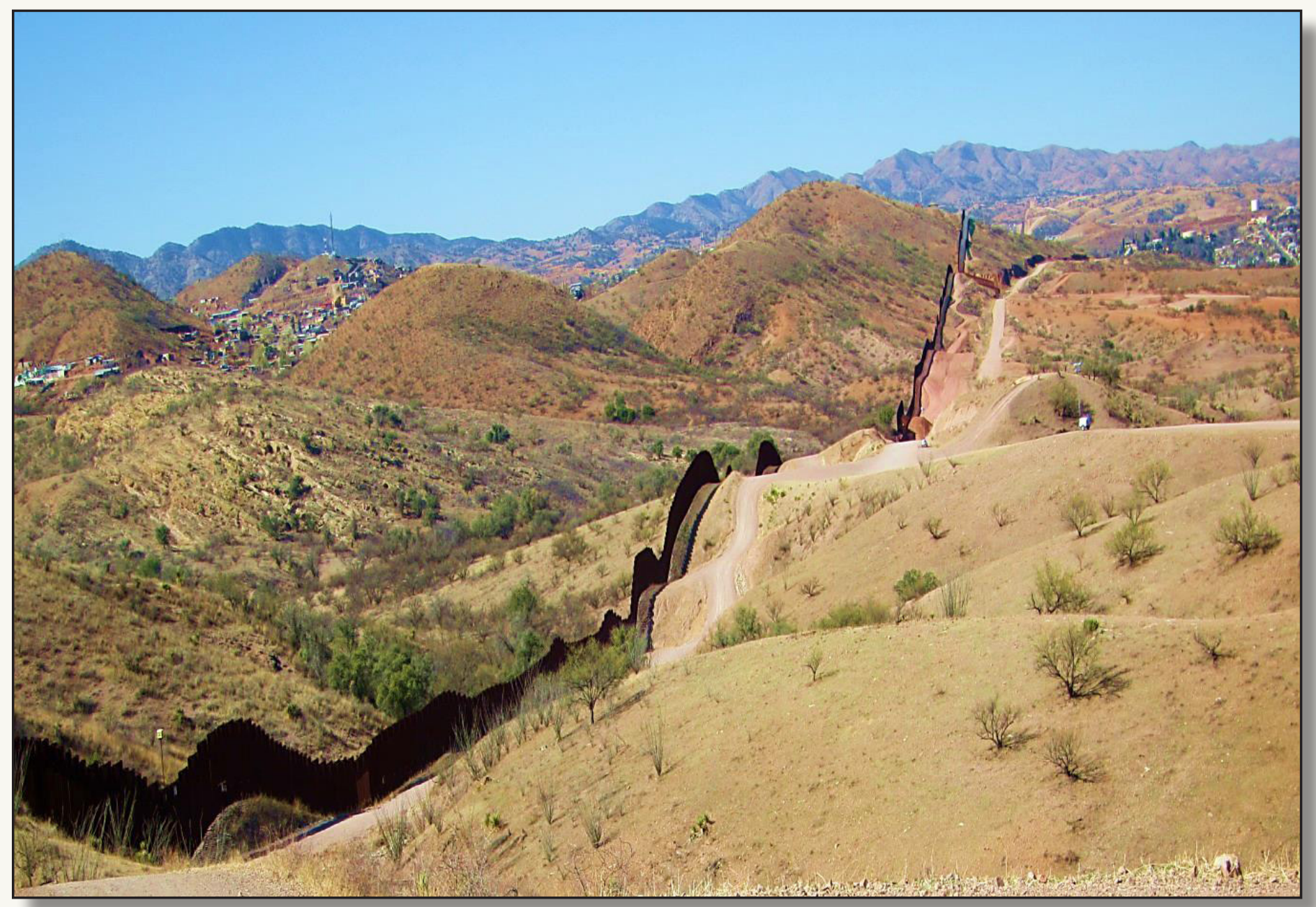

Scientific Investigations Map 3354 
Cover. Photograph of southwest view along U.S.-Mexico border fence, east of the Nogales urban area; Nogales, Sonora, is in distance on left, and Nogales, Arizona, is in upper right. Hilly terrain is mostly volcaniclastic sandstone and conglomerate of the Miocene Nogales Formation. Atascosa Mountains are on the skyline. Photograph by W.R. Page. 


\section{Geologic Map of the Rio Rico and Nogales 7.5' Quadrangles, Santa Cruz County, Arizona}

By William R. Page, Christopher M. Menges, Floyd Gray, Margaret E. Berry,

Mark W. Bultman, Michael A. Cosca, and D. Paco VanSistine

Scientific Investigations Map 3354 


\title{
U.S. Department of the Interior SALLY JEWELL, Secretary
}

\section{U.S. Geological Survey Suzette M. Kimball, Director}

\author{
U.S. Geological Survey, Reston, Virginia: 2016
}

For more information on the USGS - the Federal source for science about the Earth, its natural and living resources, natural hazards, and the environment—visit http://www.usgs.gov or call 1-888-ASK-USGS.

For an overview of USGS information products, including maps, imagery, and publications, visit http://www.usgs.gov/pubprod/.

Any use of trade, firm, or product names is for descriptive purposes only and does not imply endorsement by the U.S. Government.

Although this information product, for the most part, is in the public domain, it also may contain copyrighted materials as noted in the text. Permission to reproduce copyrighted items must be secured from the copyright owner.

Suggested citation:

Page, W.R., Menges, C.M., Gray, Floyd, Berry, M.E., Bultman, M.W., Cosca, M.A., and VanSistine, D.P., 2016, Geologic map of the Rio Rico and Nogales 7.5' quadrangles, Santa Cruz County, Arizona: U.S. Geological Survey Scientific Investigations Map 3354, 32 p. pamphlet, 2 sheets, 1:24,000-scale, http://dx.doi.org/10.3133/sim3354.

ISSN 2329-132X (online) 


\section{Contents}

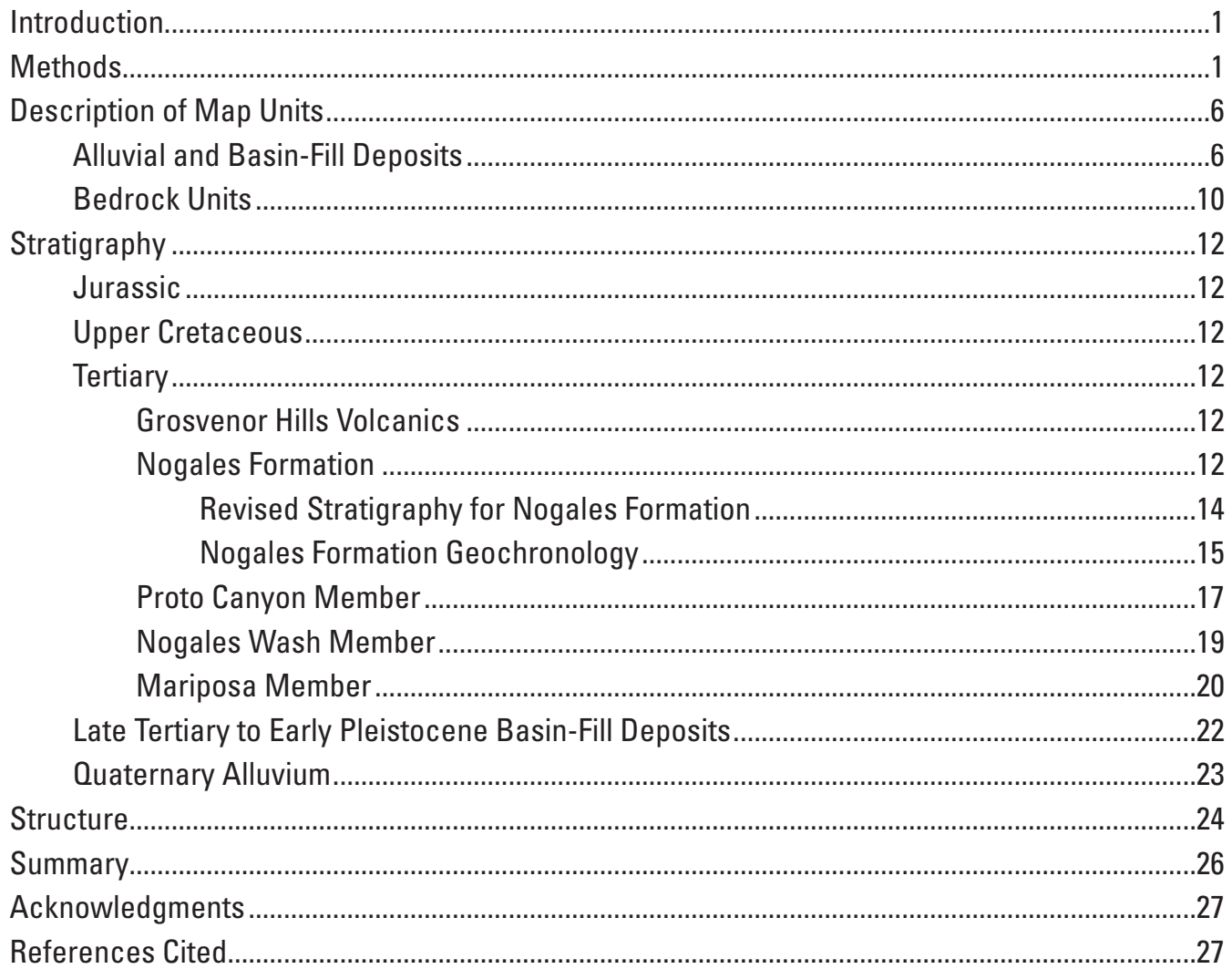

\section{Figures}

1. Location map of Rio Rico and Nogales (Arizona) 1:24,000-scale quadrangles, showing major physiographic, geologic, and hydrologic features in the map area .............2

2. Location map of upper Santa Cruz basin area, showing major physiographic, geologic, and hydrologic features in the region.........................................................

3. Stratigraphic chart of sediments and rocks in map area ................................................

4. Plots of new ${ }^{40} \mathrm{Ar} /{ }^{39} \mathrm{Ar}$ geochronology incremental heating data for amphibole and biotite analyses from the Grosvenor Hills Volcanics

5. Photograph of northeast view of ledge-forming, resistant volcaniclastic sandstone beds in the Nogales Wash member of the Nogales Formation (Tnn) overlying less-resistant arkose sandstone and conglomerate beds in the lower part of the Proto Canyon member (Tnp), east of Nogales, Arizona, along State Highway 82

6. Plots of new ${ }^{40} \mathrm{Ar} /{ }^{39} \mathrm{Ar}$ incremental-heating analyses of whole-rock samples from basalts in the Nogales Formation.

7. New ${ }^{40} \mathrm{Ar} /{ }^{39} \mathrm{Ar}$ ideogram plots for laser-fusion analyses of $A$, sanidine from rhyolite tuff in Grosvenor Hills Volcanics, $B$, detrital sanidine and plagioclase from volcaniclastic sediments in the Nogales Formation, and $C$, sanidine and plagioclase from rhyolite tuff in the Nogales Formation from Agua Fria Canyon area. 


\section{8-26. Photographs of:}

8. Basal debris-flow conglomerate in the Proto Canyon member of the Nogales Formation south of Mount Benedict, near contact with Jurassic Quartz Monzonite of Mount Benedict

9. Sequence of alternating beds of arkosic sandstone, conglomeratic sandstone, and debris-flow conglomerate in lower parts of Proto Canyon member, above basal debris-flow conglomerate; hammer in middle left for scale

10. Cliff-forming, cyclic, fining-upward, fluvial sequences in lower part of the Proto Canyon member exposed in Proto Canyon

11. Red and light-gray gravelly claystone (below black line) and overlying gray volcaniclastic sandstone (above black line) in the middle part of the Proto Canyon member exposed in Yerba Buena Canyon

12. Fluvial cross-bedded volcaniclastic sandstone and conglomerate with lag monzonite gravel in channels, in upper part of the Proto Canyon member exposed west of Grand Avenue, and north of Mariposa Road.

13. Pinkish-gray volcaniclastic sandstone in the uppermost part of the Proto Canyon member, exposed north of Mariposa Road, between Interstate 19 and Grand Avenue; pick in middle for scale

14. Boulder of Proto Canyon member exposed in Sonoita Creek area where it laps onto the Grosvenor Hills Volcanics; unit in lower part of member and consists of volcaniclastic conglomerate with clasts mostly of white and red porphyritic volcanic rocks, and brownish-gray rhyodacite derived from the Grosvenor Hills Volcanics; boulder is about $0.5 \mathrm{~m}$ in diameter

15. Massive, cliff-forming volcaniclastic sandstone and conglomeratic sandstone in the basal part of the Nogales Wash member along Grand Avenue, south of Mariposa Road.

16. Alternating thin- to thick-bedded, volcaniclastic sandstone and conglomeratic sandstone of the Nogales Wash member south of Mariposa Road and west of Grand Avenue; small-displacement fault diagonally cuts beds in center of photograph.

17. Faulted and highly rotated beds (dipping $48^{\circ}$ northwest) of Mariposa member along Interstate 19, north of Mariposa Road

18. Massive claystone unit in Mariposa member exposed south of Mariposa Road, between Interstate 19 and Grand Avenue

19. Mariposa member in basin south of Sonoita Creek and east of the Santa Cruz River, composed of alternating beds of volcaniclastic conglomeratic sandstone, sandstone, and few thin silt and clay partings; hammer and field notebook for scale.

20. Fine-grained facies of the Mariposa member in basin south of Sonoita Creek and east of the Santa Cruz River, composed of alternating beds of fine-grained volcaniclastic sandstone, siltstone, and claystone; hammer in lower left for scale

21. Sandy and gravelly claystone beds in the Mariposa member south of Sonoita Creek and east of the Santa Cruz River; height of outcrop about $3 \mathrm{~m}$ 
22. View to west of basal part of basin-fill deposits (QTa) in Potrero Canyon area .........22

23. A, View to east of reddish brown basal basin-fill deposits (QTa) in trough cut into underlying Nogales Wash member of the Nogales Formation (Tnn) in a road cut at Crawford Hill; height of outcrop about $20 \mathrm{~m}$. $B$, West view directly across Interstate 19 from road cut at Crawford Hill, showing subvertical fault (black line with arrow on downthrown side) juxtaposing Nogales Wash member (Tnn) in hanging wall, against basin-fill deposits (QTa) in footwall; height of outcrop about $18 \mathrm{~m}$.

24. Northwest view along Mount Benedict fault (black line with arrow on downthrown side) east of Santa Cruz River; gray and dark brown beds (on left) of the Salero Formation (Ks) in the footwall, and yellowish to pinkish gray beds (on right, on which geologists are standing) are the Mariposa member of Nogales Formation (Tnm) in the hanging wall; fault plane strikes N. $40^{\circ} \mathrm{W}$. and dips $65^{\circ}$ northeast.

25. Southwest view of Grand Avenue fault (black line with arrow on downthrown side) just south of Mariposa Road and west of Grand Avenue; gray sandstone of the Nogales Wash member (Tnn) on left in footwall, and pink claystone in Mariposa member (Tnm) on right in hanging wall; height of large shrub in center of photograph is about $1 \mathrm{~m}$.

26. North view along southern end of the east-dipping San Cayetano fault just south of Sonoita Creek

\section{Tables}

1. ${ }^{40} \mathrm{Ar} /{ }^{39} \mathrm{Ar}$ geochronology for Grosvenor Hills Volcanics and Nogales Formation in the Nogales and Rio Rico 1:24,000-scale quadrangles, Arizona

2. ${ }^{40} \mathrm{Ar} /{ }^{39} \mathrm{Ar}$ geochronology for Nogales Formation in the Agua Fria Canyon area (fig. 2), Peña Blanca Lake 1:24,000-scale quadrangle, adjacent and to the west of the Rio Rico quadrangle.

\section{Appendix Table}

1-1. Combined ${ }^{40} \mathrm{Ar} /{ }^{39} \mathrm{Ar}$ data for Grosvenor Hills Volcanics and Nogales Formation. (Click here to access digital file).. .29

\section{Conversion Factors}

\begin{tabular}{lcll}
\hline & Multiply & By & \multicolumn{1}{c}{ To obtain } \\
\hline inch (in.) & 25.4 & millimeter $(\mathrm{mm})$ \\
inch (in.) & 2.54 & centimeter $(\mathrm{cm})$ \\
foot (ft) & 0.3048 & meter $(\mathrm{m})$ \\
mile (mi) & 1.609 & kilometer $(\mathrm{km})$ \\
\hline
\end{tabular}





\title{
Geologic Map of the Rio Rico and Nogales 7.5' Quadrangles, Santa Cruz County, Arizona
}

\author{
William R. Page, Christopher M. Menges, Floyd Gray, Margaret E. Berry, Mark W. Bultman, Michael A. Cosca, \\ and D. Paco VanSistine
}

\section{Introduction}

The Rio Rico and Nogales (Arizona) 1:24,000-scale quadrangles are located in the Basin and Range Province of southern Arizona, and the southern edge of the map is the international border with Sonora, Mexico (figs. 1 and 2). The major urban area is Nogales, a binational city known as "the gateway to Mexico." Rocks exposed in the map area range in age from Jurassic through Quaternary (fig. 3). Major physiographic, geologic, and hydrologic features in the map area include the southern San Cayetano Mountains, Grosvenor Hills, and Sonoita Creek in the northern part, and Mount Benedict and the Mount Benedict horst block in the southcentral part (figs. 1 and 2). The horst block is bounded by the Santa Cruz River on the east and Nogales Wash (tributary to the Santa Cruz River) on the west.

The objectives of our mapping were to define the geologic framework for the Nogales area and the upper Santa Cruz basin (fig. 2) (Callegary and others, 2011; Page and others, 2011), to support ongoing multidisciplinary projects. These projects include the U.S. Geological Survey (USGS) Tucson Water Science Center Transboundary Aquifer Act Project (hydrologic and climatic modeling and water quality and quantity studies of the upper Santa Cruz basin); the United States-Mexico Border Environmental Health Initiative (evaluating contaminants in the basin and impacts to human and wildlife health); and the assessment of concealed porphyry copper deposits in the region. This work will also provide fundamental data used for flood hazard and water storage investigations in the Nogales Wash and Santa Cruz River areas, and in efforts to detect and predict the location of illegal tunnels beneath the international border. We significantly revised the Miocene Nogales Formation based on geologic mapping combined with new geochronologic, geophysical, and hydrogeologic studies. The Nogales Formation is poorly understood because it has not been mapped in detail, and in turn, its groundwater resource potential is poorly known. This new work will improve understanding of the Nogales Formation to more fully assess its groundwater resource potential (Gray and others, 2014).
Previous regional-scale geologic mapping in the area was completed by Simons (1974), Drewes (1972, 1980), and Peterson and others (1990). Gettings and Houser (1997) and Gettings (2002) described the geometry and structure of the upper Santa Cruz basin based mostly on aeromagnetic, gravity and other geophysical data, and well data. Youberg and Helmick (2001) mapped the adjacent Tubac and Amado 1:24,000-scale quadrangles (fig. 2), with emphasis on defining the surficial geology in terms of assessing geologic hazards and geomorphology.

\section{Methods}

Bedrock geology was digitally mapped in ArcMap (version 9.3.1), with the aid of 2010 National Agriculture Imagery Program (NAIP) orthophotography, imagery viewed with Google Earth, 1996 National Aerial Photography Program (NAPP) 1:40,000-scale color infrared aerial photographs, and $1: 24,000$ and 1:100,000-scale topographic maps. Mesozoic bedrock units were compiled from existing published geologic maps in the area, including those of Simons (1974), and Drewes (1972, 1980); most bedrock unit descriptions were from these reports with minor modifications, and the location of some contacts and faults were slightly adjusted based on interpretation of orthophotography and imagery viewed with Google Earth. Simons (1974) mapped numerous northwest-trending dikes in the Jurassic Quartz Monzonite of Mount Benedict and in the Salero Formation in the San Cayetano Mountains. These dikes were not shown on this geologic map because of difficulty georeferencing and reproducing their precise locations; see Simons (1974) for location and description of these dikes.

Due to the scarcity of deep drill holes with subsurface data in the map area, the location, geometry and thickness of the Nogales Formation, and estimated depth to Cretaceous and Jurassic bedrock shown in cross sections were based primarily on geophysical models, combined with data from surface outcrops. Contacts between members of the Nogales Formation are approximately located in cross sections, where not constrained by nearby outcrops. 


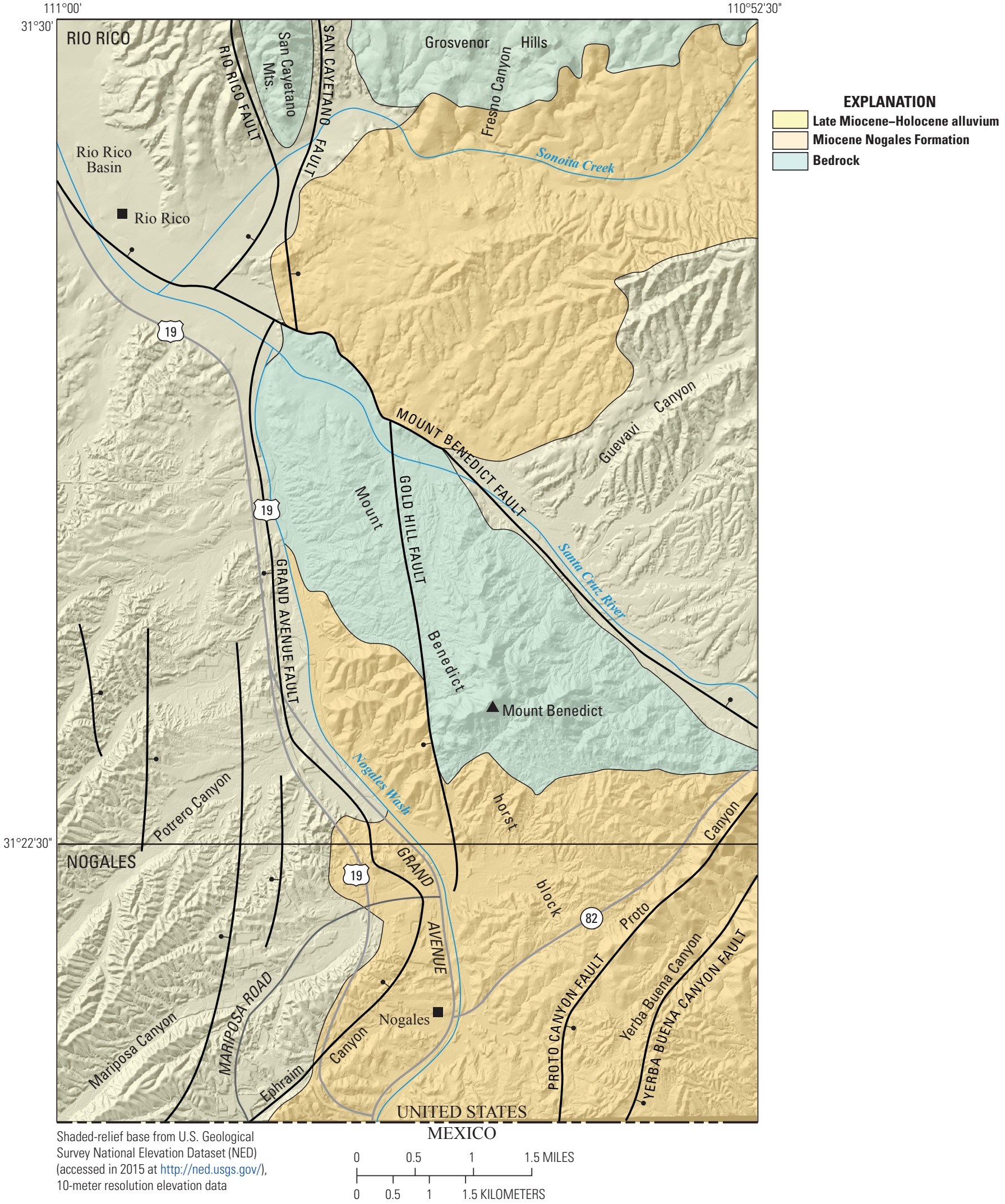

Figure 1. Location map of Rio Rico and Nogales (Arizona) 1:24,000-scale quadrangles, showing major physiographic, geologic, and hydrologic features in the map area. Black squares are town locations and black ball and bar symbols indicate the downthrown side of normal faults. 


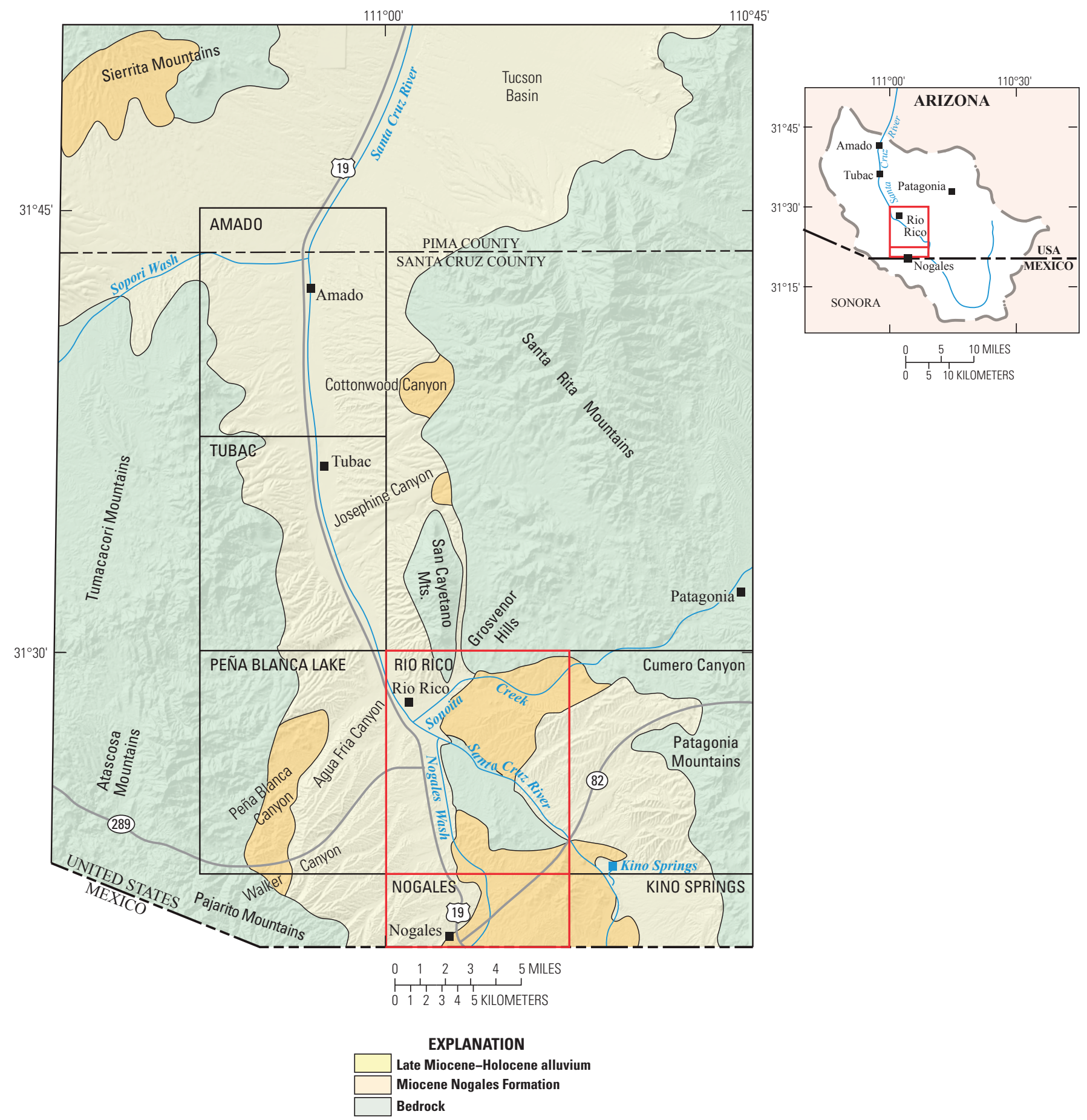

Figure 2. Location map of upper Santa Cruz basin area, showing major physiographic, geologic, and hydrologic features in the region. Black squares are town locations. Inset map in upper right shows location of upper Santa Cruz River basin with boundary in gray, Santa Cruz River (SCR) in blue, and boundaries of Rio Rico and Nogales quadrangles in red. 


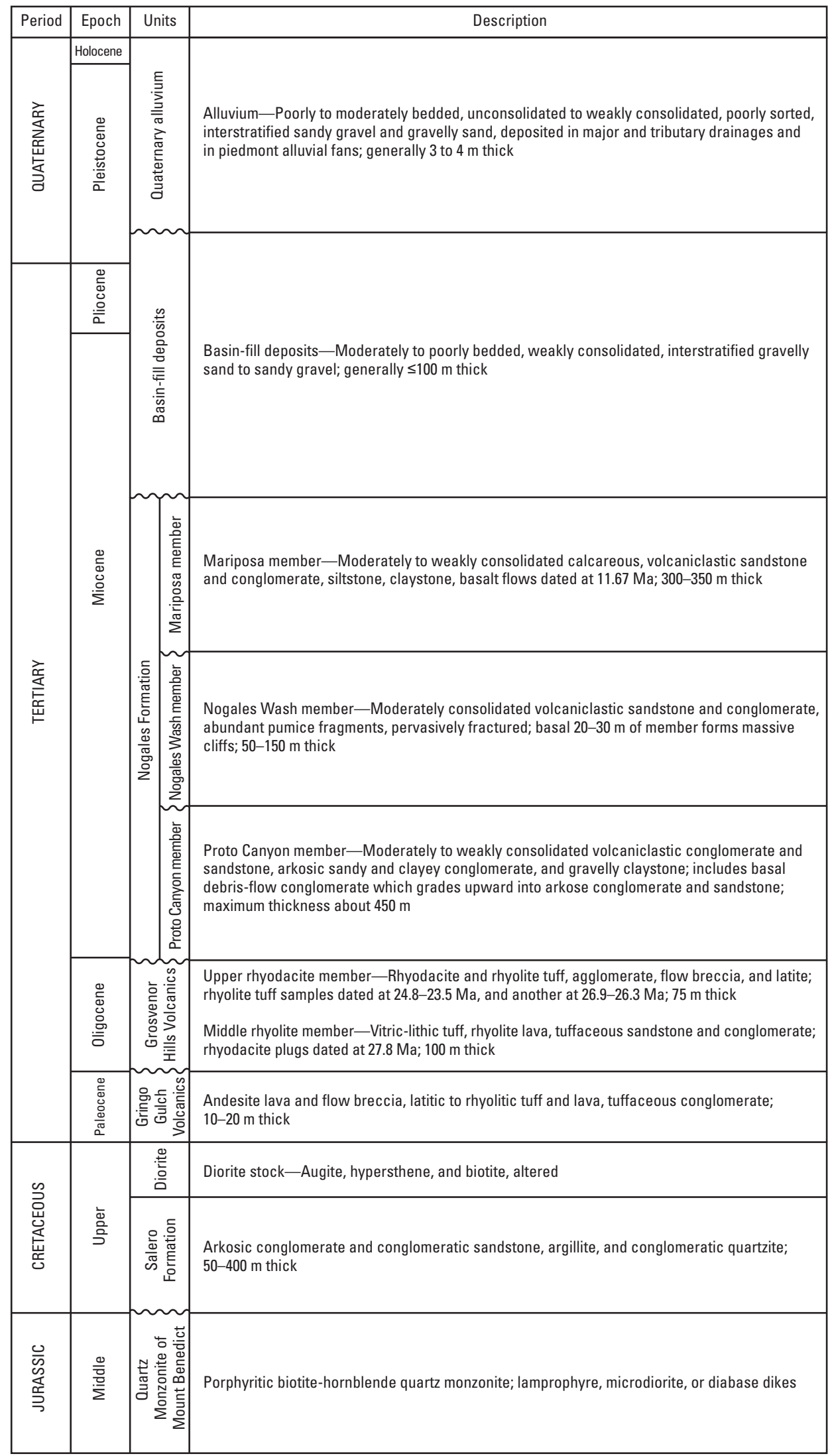

Figure 3. Stratigraphic chart of sediments and rocks in map area. Unconformities and disconformities are indicated by the wavy line. 
Most previous geologic mapping within the Rio Rico-Nogales area could not be used in the compilation of Quaternary surficial deposits, because these published maps do not define Quaternary units in sufficient levels of detail or coverage. Thus, the surficial geology in the map area was compiled from interpretation of stereoscopic pairs of 1996 NAPP color-infrared aerial photography (1:40,000-scale), 2010 NAIP orthophotography, imagery viewed with Google Earth, topographic data, and digital soils data (U.S. Department of Agriculture Natural Resources Conservation Service, 2008), using previous mapping in adjacent areas by Youberg and Helmick (2001) and Helmick (1986) as a guide. The surficial geology was digitally mapped on the NAIP imagery using ArcMap GIS software. Interpretive mapping was constrained by, and unit description and age estimates are based on data collected at GPS-located field stations along a series of traverses. Terrace heights were estimated from 1:24,000-scale topographic maps, Digital Elevation Model (DEM) data, and for lower (younger) units, local field measurements.

Surficial units are classified and mapped on the basis of both their genesis and relative age. These units are primarily alluvial in origin and were deposited either by axial streams and their major tributaries or by distributed, shallow, channel systems on piedmont alluvial fans, which also include sediment deposited by debris flows. Age estimates for the deposits are based primarily on age-related physical characteristics that change progressively with time. Chief among these are preservation of original depositional form or microtopography (for example, bar-and-swale morphology), development of desert pavement, degree of varnish development and amount of physical weathering of clasts (Bull, 1991), and the degree of soil development. The latter includes depth and degree of alteration of surficial deposits (parent materials), accumulation of secondary materials (such as eolian silt, illuvial clay, and (or) carbonate), and soil horizon morphology (Birkeland, 1999). The relative heights of stream-terrace and tributary-fan deposits provide an additional constraint on age estimates, because progressive and persistent dissection of major and tributary drainage systems, punctuated by periodic depositional events, produces a series of deposits where progressively younger deposits are inset within and topographically lower than older deposits. No radiometric ages have been obtained for Pliocene or Quaternary deposits in the map area. Thus general age designations for these units are based on correlations with chronosequences developed in adjacent mapped areas (Helmick, 1986; Pearthree and Biggs, 1999; Pearthree and Youberg, 2000; Youberg and Helmick, 2001; Lindsey and Van Gosen, 2010).

(Division of Pliocene-Quaternary time used in this report is from Cohen and others [2014]: Pliocene, 5.33-2.58 Ma; early Pleistocene [Calabrian and Gelasian], 2.58 Ma-781,000 yr; middle Pleistocene 781,000-126,000 yr; late Pleistocene, 126,000-11,700 yr; Holocene, 11,700-0 yr. Map unit symbols for Quaternary deposits follow Youberg and Helmick (2001) to retain consistency with previous mapping in adjacent areas). 


\section{DESCRIPTION OF MAP UNITS}

\section{ALLUVIAL AND BASIN-FILL DEPOSITS}

Qycr Active river-channel deposits (latest Holocene)-Modern river channel deposits of Youberg and Helmick (2001). Alluvium transported and deposited by discrete channel systems during the past several years to decades. Unit mapped mostly along sections of the Santa Cruz River, Nogales Wash, and Sonoita Creek (fig. 1). Channels are anastomosing to braided systems of small subchannels and low bars (local relief as much as $1-2 \mathrm{~m}$ ) within a larger discrete meandering channel belt up to tens of meters wide. In urbanized areas of Nogales, from the diversion tunnel north of the international border to the Mariposa Canyon area, channel of Nogales Wash is artificially restrained within concrete abutments. Deposits are composed of unconsolidated, poorly to moderately sorted, weakly to moderately bedded, and interstratified silt, fine to coarse sand, and pebble- cobble-, and locally small-boulder gravel. Clasts rounded to subangular. No discernible modification of original depositional surfaces. No soil development other than very thin $(\leq 1-2 \mathrm{~cm})$ surface crusts composed of silt and very fine sand in channel reaches that have not had recent flows. Most reaches currently experience discontinuous, intermittent to ephemeral flow, with the exception of Nogales Wash and nearby downstream reaches of the Santa Cruz River that receive limited perennial artificial recharge from south of the international border at Nogales. Many channels locally contain significant sparse to dense growths of riparian vegetation. Most large channels are prone to moderate to extreme flow discharges during prolonged and (or) intense precipitation events. Larger flooding episodes commonly are associated with major sediment transport, deposition, and local erosion within channels and adjacent lowland areas. Main channel system generally incised 1-5 m below lowest river terraces of units Qyr2 and Qyr1. Much of the most recent valley incision is related to pronounced arroyo incision that initiated in the late 1880s along all major drainages in the region (Betancourt, 1990; Wood and others, 1999). Estimated thickness $1-3 \mathrm{~m}$

Young river floodplain and terrace deposits (late Holocene) — Part of Holocene floodplain and terrace deposits of Youberg and Helmick (2001). Alluvial deposits associated with floodplain and lowest-level river terraces flanking main channels on valley floors of major drainages. Surfaces occasionally flooded. Mapped mostly along sections of the Santa Cruz River, Nogales Wash, and Sonoita Creek. Locally includes active channel deposits too narrow to map separately. Unit associated with flat to gently undulating (local relief generally $<50 \mathrm{~cm}$ ), low floodplain surfaces, many abandoned after post-1880s arroyo cutting, and one or more higher terraces within heights of 1 to $2 \mathrm{~m}$ above adjacent active channels. Deposits are composed of unconsolidated, poorly to moderately sorted, poorly to moderately bedded, and interstratified sand, silt, and pebble-, cobble-, and locally small-boulder gravel, with a larger percentage of fine-grained components in the upper part of the unit. Clasts rounded to subangular. Surfaces typically extensive and undissected. Original depositional surfaces artificially altered to varying degrees by agricultural development or urbanization, but display little to no natural surface modification. Soil development weak and restricted to the accumulation of fine silt and sand at shallow depths. Estimated thickness 1-3 m

Qyr1 Young river terrace deposits (Holocene) - Part of Holocene floodplain and terrace deposits of Youberg and Helmick (2001). Alluvial deposits associated with low-level river terraces on valley floors of major drainages. Surfaces have not received discharge or alluvial sediment in the past several decades to millennium. Mapped primarily along the Santa Cruz River, Nogales Wash, and Sonoita Creek. Locally includes active channel deposits too narrow to map separately. Unit associated with terrace surfaces about $2-5 \mathrm{~m}$ above adjacent active channels and 1-3 m above lower Qyr2 terraces. Deposits are composed of weakly consolidated, poorly to moderately sorted, poorly bedded, and interstratified silt, sand, and pebble to cobble gravel. Clasts rounded to subangular. Original depositional surfaces artificially altered by agricultural development or urbanization. Natural surface modification limited to some smoothing of original depositional surfaces and development of light varnish on surface clasts. Incipient to weak soil development to depths of 1-1.5 m. Soils on the highest (oldest) terraces characterized by $\mathrm{A}$ or $\mathrm{Av}, \mathrm{Bw}$, and $\mathrm{Bk}$ horizons with stage I carbonate morphology. Estimated thickness 1-3 m (2001). Deposits associated with channels, adjacent floodplains, low terraces, and small alluvial fans along tributaries to major drainages. Locally includes deposits forming narrow alluvial plains at the toe of piedmont slopes along the Santa Cruz River valley margin. Most surfaces are 0.5 to $3 \mathrm{~m}$ above active local channels. Lower surfaces rarely to occasionally flooded within decadal to millennial time scales by high- 
discharge runoff during extreme precipitation events, whereas higher surfaces are rarely if ever inundated. Deposits are composed of unconsolidated to very weakly consolidated, poorly to moderately sorted, poorly bedded, and interstratified sand, silt, and pebble to cobble gravel, with an increase in fine-grained sediment near the top of the unit. Locally contains a few scattered small boulders. Clasts rounded to subangular. Clast size and relative abundance typically decrease downstream from mostly sandy pebble-cobble gravel in upland reaches to sand and pebbly gravel in distal reaches. Unit subdivided into Qy2 and Qy1 where more than one set of Holocene alluvial deposits are discernible. Estimated thickness 1-3 m

Younger of the young alluvial deposits (late Holocene) - Late Holocene alluvium of Youberg and Helmick (2001). Deposits associated with channels, adjacent floodplains, lowest terraces, and small alluvial fans along tributary drainages. Forms surfaces mostly 0.5 to $2 \mathrm{~m}$ above active local channels in tributary drainages and at the toe of piedmont slopes along the Santa Cruz River valley margin. Surfaces generally flat to gently undulating, and undissected with minimal or no modification of original depositional surface. No to very weak soil development, limited to thin fine-grained A horizons developed on some terrace surfaces. Estimated thickness $1-3 \mathrm{~m}$

Older of the young alluvial deposits (Holocene) - Holocene alluvium of Youberg and Helmick (2001). Deposits associated with low terraces locally preserved along margins of incised tributary valleys at heights of 2 to $3 \mathrm{~m}$ above active channels; also may include some small fan remnants near canyon mouths of the tributary drainages. Surfaces generally flat to gently undulating with minor dissection by widely spaced shallow rills. Some smoothing of original depositional surfaces, poorly preserved bar-and-swale morphology, and incipient pavement development. Some surface clasts are physically weathered and (or) lightly varnished. Very weak to weak soil development, about 1-1.5 m deep, characterized by Av, Bw, and Bk horizons with thin stage I carbonate morphology. Estimated thickness 1-3 m Youberg and Helmick (2001). Alluvial deposits associated with intermediate-height terraces preserved along valley margins of major drainages. Unit mapped along sections of Santa Cruz River, Nogales Wash, and Sonoita Creek. Terrace surfaces are generally 8 to $25 \mathrm{~m}$ above active channels, and flat to gently sloping with mostly minor low-relief dissection. Deposits are composed of unconsolidated, poorly sorted, poorly bedded, and interstratified sand, gravelly sand, and sandy pebble-, cobble-, and minor boulder-gravel. Clasts subangular to rounded. Varnish on surface clasts imparts orange to reddish-brown coloration to terrace surfaces in outcrop and on color photographic imagery. Unit subdivided into Qlr2 and QIr1 where more than one set of late Pleistocene alluvial deposits are discernible. Thickness typically 1 to $2 \mathrm{~m}$, but locally up to 3 to $4 \mathrm{~m}$

Younger of the young intermediate river-terrace deposits (late Pleistocene) - Part of late Pleistocene river terraces of Youberg and Helmick (2001). Generally forms the more prominent, wider and less dissected set of terraces, at heights of 8 to $15 \mathrm{~m}$ above adjacent channels. Surfaces have weakly to locally moderately developed pavement, light-toned orange to pale red varnish, and weak to locally moderate physical clast weathering. Generally moderate soil development, to depths of 1-1.5 m, characterized by distinct Av horizons, weak to moderately developed Bt horizons, and Bk horizons with stage I-II carbonate morphology. Typically 1 to $2 \mathrm{~m}$ thick races of Youberg and Helmick (2001). Generally forms terraces with minor to moderate dissection, at heights of 10 to $25 \mathrm{~m}$ above adjacent channels. Surfaces have weakly to moderately developed pavements, bright orange to reddish-brown varnish, and weak to moderate physical clast weathering. Moderate soil development, to depths of 1-1.5 m, characterized by distinct Av horizons, weak to moderately developed Bt horizons, and Bk horizons with stage II carbonate morphology. Typically 1 to $2 \mathrm{~m}$ thick Helmick (2001). Deposits associated with intermediate-height terraces and alluvial fans along tributaries to major drainages. Top of unit commonly projects to, or grades to top of unit QIr. Deposits of unit QI typically overlie older sediments and (or) bedrock. Surfaces flat to gently undulating benches at heights of 5 to $25 \mathrm{~m}$ above adjacent channels. Deposits are composed of unconsolidated, poorly sorted, poorly bedded, and interstratified sand, gravelly sand, and sandy gravel. Clasts mainly subrounded to subangular and range in size from pebbles to cobbles, with local scattered small boulders. Varnish on surface clasts imparts an overall orange to reddish brown coloration to surfaces in outcrop and color photographic imagery. Unit subdivided into QI2 and Q11 where more than one set of late Pleistocene alluvial deposits are discernible. Typically 1 to $2 \mathrm{~m}$ thick 
Younger of the young intermediate alluvial deposits (late Pleistocene) - Latest Pleistocene member of Youberg and Helmick (2001). Forms benches 5 to $10 \mathrm{~m}$ above adjacent channels in valley floors of tributary drainages. Surfaces slightly dissected by widely spaced gullies and rills 1 to $2 \mathrm{~m}$ deep. Original surface morphology slightly to moderately modified by weak to locally moderate pavement, light-toned orange to palered varnish, and weak to locally moderate physical clast weathering. Moderate soil development, to depths of 1-1.5 m, characterized by distinct Av horizons, weakly to moderate developed Bt horizons, and Bk horizons with stage I-II carbonate morphology. Typically 1 to $2 \mathrm{~m}$ thick

Older of the young intermediate alluvial deposits (late Pleistocene) - Late Pleistocene member of Youberg and Helmick (2001). Forms benches 12 to $25 \mathrm{~m}$ above adjacent channels in valley floors of tributary drainages. Surfaces characterized by broad, gently rounded to locally flat interfluves interspersed with widely spaced gullies and rills 2 to $5 \mathrm{~m}$ deep. Original depositional surface modified by moderate to weak pavement development, moderate to locally strong reddish brown to orange varnish, and moderate to weak physical clast weathering. Generally moderate soil development, to depths of 1-1.5 m, characterized by distinct Av horizons, weakly to moderately developed Bt horizons, and Bk horizons with stage I-II+ carbonate morphology. Typically 1 to $2 \mathrm{~m}$ thick

Qmr

Older intermediate river-terrace deposits (middle Pleistocene) - Middle Pleistocene river terrace deposits of Youberg and Helmick (2001). Alluvial deposits associated with scattered remnants of high-level terraces along Sonoita Creek. Terrace deposits form accordant series of broad, rounded, isolated benches, 5 to $10 \mathrm{~m}$ wide and about 30 to $40 \mathrm{~m}$ above active channels of adjacent drainage. Deposits are composed of unconsolidated, poorly sorted, poorly bedded, interstratified sand and gravel. Clasts mainly subangular to rounded and range in size from pebbles to cobbles, with scattered small boulders. Surfaces typically have moderate to strong modification of original morphology, with moderate to locally strong pavements that subsequently have been partially stripped, moderate to strong physical clast weathering, and moderate to strong varnish on surface clasts. Varnish on surface clasts imparts dark-reddish-orange to brown coloration to terrace surfaces in outcrop and on color photographic imagery. Locally eroded, moderately to strongly developed soils, about 1-2 $\mathrm{m}$ thick, characterized by well-developed, clay-rich Bt horizons, and Bk and cemented $\mathrm{K}$ horizons with stage II+ and III+ carbonate morphology, respectively. Typically 1 to $3 \mathrm{~m}$ thick terraces and alluvial fans related to tributary drainages. Surfaces typically strongly dissected, with broad, rounded interfluves, and benches at relative heights of 10 to $30 \mathrm{~m}$ above incised tributary channels. Deposits are composed of unconsolidated, poorly sorted, poorly bedded, and interstratified sand and gravel. Clasts mainly subangular to rounded, and range in size from pebbles to cobbles with scattered small boulders. Moderate to strong modification of original surface morphology, with moderate to locally strong pavements that subsequently have been partially stripped, moderate to strong physical clast weathering, and moderate to strong varnish on surface clasts. Varnish on surface clasts imparts dark reddish-brown or orange-brown coloration to surfaces in outcrop and on color photographic imagery. Locally eroded, moderately to strongly developed soils, about 1-2 m thick, characterized by well-developed, clay-rich Bt horizons, and Bk and cemented $\mathrm{K}$ horizons with II to III+ carbonate morphology, respectively. Typically 0.5 to $3 \mathrm{~m}$ thick fan deposits preserved on a ridge crest about $170 \mathrm{~m}$ above the channel of the Santa Cruz River near the northwestern corner of the map area, where the deposits overlie unit QTa. North of the map area, unit is more extensively preserved east and west of the Santa Cruz River (Youberg and Helmick, 2001; Lindsey and VanGosen, 2010). Deposits are composed of moderately to thickly bedded, moderately to weakly consolidated sandy gravel to gravelly sand. Clasts typically subrounded to angular, and range in size from pebbles to cobbles, with a few scattered small boulders. Clasts are derived locally from adjacent highlands. Original surface is strongly modified and only partially preserved, with some erosional remnants of strongly to moderately varnished surface clasts on partially stripped former pavements. Locally preserved surface soil is characterized by a strongly developed Bt horizon above a well cemented $\mathrm{K}$ horizon with stage IV-V carbonate morphology, which includes laminar carbonate at the top of the $\mathrm{K}$ horizon. Deposits range in thickness from 1 to $2 \mathrm{~m}$ above exposures of gently westward sloping basal contact consists of stratified sequences of mostly alluvial-fan deposits that are deeply eroded and dissected into a 
series of ridges and ravines (ballena topography), with local relief of 10 to $70 \mathrm{~m}$. No original depositional surfaces are preserved. Deposits are composed of light-reddish-brown, and pinkish-gray to light-gray, weakly consolidated, moderately to poorly bedded, and interstratified sandy gravel and gravelly sand. Locally includes finer-grained sections of mostly sand and pebbly sand. Bedding contacts diffuse to gradational in character. Clasts commonly subangular to subrounded, and range in size from pebbles to cobbles. Clasts are composed of various rock types exposed along basin margins. Volcanic rock types, including rhyolite, rhyodacite, and dacitic flows and tuffs, are most common, but some sections, especially near the base of unit, contain significant granitic clasts in areas near exposed granitic bedrock. Vertical exposures of unit erode to form characteristic shallow vertical fluting that crosscuts bedding. Bedding dips are typically shallow and oriented in a basinward direction. Generally few fractures, faults or bedding partings are present in most exposures. Unit differentiated from sediments of the underlying Nogales Formation based on weak induration, diffused bedding, vertical fluting in outcrop, and general absence of deformation. The exception is the basal part of the unit, which exhibits local internal faulting, and is slightly more indurated and has greater stratal tilt relative to sediments higher in the unit. Basal part of unit QTa is faulted against the informally named Mariposa member of Nogales Formation along Interstate 19 south of Potrero Creek; along the Rio Rico fault on the west flank of the San Cayetano Mountains (fig. 2), where unit QTa in the hanging wall is faulted against Salero Formation in the footwall; and at Crawford Hill where unit QTa is faulted against the Nogales Wash member (informal name) of the Nogales Formation. Thickness of unit poorly constrained, but exposed sections, combined with subsurface estimates based on geophysical and borehole data, suggest thicknesses of 50-100 m; possibly as much as $150 \mathrm{~m}$ thick in deeper subbasins

Alluvium and basin-fill deposits, undivided (Holocene to Miocene) - Shown in cross sections only; maximum thickness about $150 \mathrm{~m}$

Nogales Formation (Miocene) - Includes informally named Mariposa, Nogales Wash, and Proto Canyon members; maximum age of formation is about 20 to $18 \mathrm{Ma}$, and minimum age is about $11 \mathrm{Ma}$ (Cosca and others, 2013); combined maximum thickness estimated at $950 \mathrm{~m}$

Tnm

Mariposa member - Exposed in vicinity of Mariposa Road and Interstate 19, in basin south of Sonoita Creek and east of Santa Cruz River, and in southeastern part of map near international border. In Mariposa Road and Interstate 19 areas, consists mostly of grayish-orange-pink to pinkish-gray, moderately to weakly consolidated, alternating beds of volcaniclastic, calcareous, conglomerate and sandstone. Conglomerate and sandstone are coarse- to fine-grained and contain subangular to subrounded grains of quartz (some polymictic), plagioclase, biotite, hornblende, porphyritic volcanic rocks, pumice fragments, and altered volcanic glass. Member locally contains grayish-orange-pink claystone unit in Mariposa Road area (between Grand Avenue and Interstate 19); about 30 to $40 \mathrm{~m}$ of unit is exposed, but total thickness may be $60 \mathrm{~m}$ or more. Claystone is weakly consolidated and has some sandstone and conglomeratic sandstone interbeds. Claystone is calcareous, and some beds contain white, rounded pumice fragments, and angular quartz and biotite grains. Claystone unit gradational with overlying sandstone and conglomerate. In basin south of Sonoita Creek and east of Santa Cruz River, member contains units like those in urban Nogales, but conglomerate and sandstone is less coarse, and units represent a finer-grained facies, consisting of alternating beds of fine-grained, volcaniclastic sandstone, siltstone, and claystone. Exposed claystone beds are grayish-orange-pink, poorly sorted, calcareous, and sandy to gravelly like those in urban Nogales, but are generally thinner, and range from 0.5 to $3 \mathrm{~m}$ thick. Along the international border in the southeastern part of the map, only lower part of Mariposa member is exposed and consists of grayish-orange, volcaniclastic, pebble conglomerate with mostly subangular, light-brownish-gray porphyritic volcanic clasts, and some fine to medium grained, subangular to subrounded, volcaniclastic sandstone containing mostly porphyritic biotite- and hornblende-bearing rocks. In this area, member contains thin discontinuous, medium dark gray, olivine basalt flows (indicated by stipple pattern). Basalt flows are 3 to $5 \mathrm{~m}$ thick, and have a ${ }^{40} \mathrm{Ar} /{ }^{39} \mathrm{Ar}$ age of $11.67 \pm 0.09 \mathrm{Ma}$ (Cosca and others, 2013; table 1). Member is generally disconformable with overlying unit QTa, and is exposed in scattered isolated outcrops where it is about $80-100 \mathrm{~m}$ thick, but maximum thickness is estimated to be $350 \mathrm{~m}$ in deeper basins of Mariposa Road, and along the international border from Ephraim Canyon to about $4 \mathrm{~km}$ east of Grand Avenue. Member is mostly moderately consolidated, pinkish-gray, yellowish-gray, and grayish-orange-pink, alternating thin- to thick-bedded, fine- to coarse-grained volcaniclastic sandstone, conglomeratic sandstone, and minor siltstone and claystone; grains are poorly to moderately sorted, subangular to subrounded, and are composed of pumice fragments, quartz, plagioclase, biotite, hornblende, biotite- and hornblende-bearing por- 
phyritic volcanic grains, and minor chert, microcline, spherulite fragments, and altered volcanic glass. Beds typically contain tabular planar crossbeds, and few show mudcracks, bioturbation, and leaf impressions. Unit locally contains fining-upward sequences of conglomeratic sandstone at the base, medium-grained sandstone in the middle, and fine-grained sandstone and siltstone at top. The basal 20 to $30 \mathrm{~m}$ forms distinctive massive cliffs composed of pinkish-gray, moderately well consolidated volcaniclastic sandstone and conglomeratic sandstone, with abundant pumice fragments. Member is pervasively fractured in most places in map area, and is disconformable with overlying Mariposa member. Thickness estimated at about 50 to $150 \mathrm{~m}$

Proto Canyon member-Upper part consists mostly of thin-bedded, moderately consolidated, poorly sorted, fine- to coarse-grained, yellowish-gray to pinkish-gray volcaniclastic sandstone and conglomerate, with subangular to subrounded grains of quartz (some coarser grains polymictic), plagioclase, biotite, hornblende, pumice, porphyritic biotite- and plagioclase-bearing volcanic grains, and altered volcanic glass. Some beds show trough crossbedding, and contain monzonite cobble to pebble lag gravel in channels. Middle parts of the member consist of alternating beds of yellowish-gray, poorly sorted, volcaniclastic sandstone and conglomerate; pale-red sandy and gravelly claystone; and pale-red clayey and sandy arkosic conglomerate that contains poorly sorted, subangular clasts of monzonite. Below middle part of unit and above the basal conglomerate are cyclic, fining-upward fluvial sequences; cycles generally consist of (from base to top) pinkishgray monzonite clast conglomerate, massive gray-weathering volcaniclastic conglomeratic sandstone, and white horizontally bedded pumice-rich siltstone; sequences also contain some debris-flow conglomerate beds. The cyclic sequences form massive cliffs in the Proto Canyon area south of State Highway 82. Basal conglomerate consists mostly of grayish-red, clast-supported monzonite boulder, cobble and pebble debrisflow conglomerate which grades upward into pale-reddish-brown, weakly consolidated arkose sandstone and conglomerate with monzonite boulders, cobbles, and pebbles. North of State Highway 82, member includes dacite dikes (Tnpd) intruding unnamed north-northeast striking fault cutting arkose conglomerate units in lower part of the Proto Canyon member. Dacite is greenish-gray to light-olive-gray, and consists mostly of phenocrysts and granular clots of plagioclase, and lesser amounts of amphibole, biotite, pyroxene, and some quartz and feldspar inclusions; dikes 1 to $2 \mathrm{~m}$ thick. In the Sonoita Creek area, the Proto Canyon member consists of upper and lower parts; upper part is mostly thin-bedded, fine-grained, moderately sorted, volcaniclastic sandstone and conglomeratic sandstone which weathers to form distinctive rounded ledges. Lower part is volcaniclastic conglomerate and sandstone with cobbles, pebbles, and grains primarily of subangular white and red porphyritic volcanic rocks, rhyodacitic to rhyolitic tuff, pumice, and some basal debris-flow conglomerate eroded mostly from the upper rhyodacite member of the Grosvenor Hills Volcanics. Proto Canyon member is unconformably overlain by the Nogales Wash member, and by the Mariposa member where the Nogales Wash member is absent. Member thickness variable, but maximum thickness about $450 \mathrm{~m}$

\section{Bedrock Units}

Grosvenor Hills Volcanics (Oligocene) —Descriptions from Simons (1974) and Drewes (1972). Consists of rhyolite member, rhyodacite and rhyolite intrusive rocks (Tr), and rhyodacite members of Drewes (1972); basal silt and clay member of Drewes (1972) not exposed in map area; combined thickness for the unit about $175 \mathrm{~m}$ thick in map area (Drewes, 1972)

Tghu

Upper rhyodacite member - Dark gray to dark brown, rhyodacite agglomerate, grayish-red, brownish-gray, and light-gray, coarse-grained porphyritic biotite-hornblende rhyodacitic tuff, rhyolite tuff, flow breccia, tuff breccia, and biotite latite tuff. In western part of southern Grosvenor Hills, upper part is brownish-gray coarse-grained porphyritic biotite rhyodacitic agglomerate with blocks up to $1 \mathrm{~m}$ across. In Fresno Canyon area (fig. 1 and sheet 1), unit consists of tuff breccia, flow breccia, and some gray to grayish red hornblendehypersthene-biotite vitrophyre. ${ }^{40} \mathrm{Ar} /{ }^{39} \mathrm{Ar}$ geochronology on a rhyolite tuff (sample 12SCB03, table 1) yielded ages ranging from 24.4 to $23.5 \mathrm{Ma}$ on sanidine single-grain laser fusion analyses, and a plateau age of age of $24.1 \pm 0.5 \mathrm{Ma}$ (Cosca and others, 2013; table 1). Another rhyolite tuff collected from a lower stratigraphic level in the unit (sample 12SCB04, table 1) produced ${ }^{40} \mathrm{Ar} /{ }^{39} \mathrm{Ar}$ plateau ages of $26.3 \pm 0.7 \mathrm{Ma}$ for amphibole (one grain) and 26.9 $\pm 0.2 \mathrm{Ma}$ for biotite (Cosca and others, 2013; table 1)

$\operatorname{Tr}$

Rhyodacite and rhyolite intrusive rocks-Mostly brownish- to pinkish-gray porphyritic rhyodacite and rhyolite dikes and plugs north of Sonoita Creek. ${ }^{40} \mathrm{Ar} /{ }^{39} \mathrm{Ar}$ geochronology analyses of one amphibole grain from this unit (sample 12SCB05, table 1) yielded a plateau age of $27.8 \pm 0.3 \mathrm{Ma}$ and a near-plateau age from a single biotite grain of 27.6 $\pm 0.4 \mathrm{Ma}$ (fig. 4) (Cosca and others, 2013; table 1) 
Tghm Middle rhyolite member-Mostly orange-pink and light-gray biotite rhyolitic, vitric, lithic tuff, and some rhyolite lava, agglomerate, tuff breccia and volcaniclastic conglomerate and sandstone. In Fresno Canyon area, lower part of member includes (1) pale-red spherulitic rhyolite with flow layering, (2) red, brown, and dark green and gray well-bedded volcaniclastic sandstone and tuff, and (3) grayish-red fined grained porphyritic biotite andesite and andesitic agglomerate

Tv

Tgg

$\mathrm{Kd}$

Ks

$\mathrm{Jb}$

$\mathrm{Jbm}$

KJu

Tertiary volcanic rocks undivided (Oligocene) — Cross section only; consists of Grosvenor Hills Volcanics and equivalent rocks; about 100 to 300 m thick

Gringo Gulch Volcanics (Paleocene) - Description from Simons (1974). Mostly green, greenish-gray, and reddish-purple pyroxene andesite lava and flow breccia; andesitic tuff and breccia; light-gray to pink latitic to rhyolitic tuff and lava; and coarse polymictic volcanic conglomerate. Only exposed on northeast edge of map, and about $60 \mathrm{Ma}$, based on geologic relations and radiometric ages for rocks above and below the unit northeast of map area (Drewes, 1972). Most of unit exposed to the northeast of the map area, along upper Sonoita Creek, southwest of Patagonia; about 10 to $20 \mathrm{~m}$ thick

Diorite (Upper Cretaceous) - Stock composed of highly weathered and altered grayish-red, fine-grained diorite on southern border of map area, in downtown Nogales; about 90 percent (or greater) altered plagioclase, 10 percent (or less) augite, hypersthene, and biotite. Simons (1974) also reported some porphyritic biotite latite and rhyolite in easternmost exposures of unit in the map area. Similar stocks in the southern Santa Rita Mountains were dated at $67 \mathrm{Ma}$ (Drewes, 1980)

Salero Formation (Upper Cretaceous) - Exposed along Santa Cruz River southeast of Sonoita Creek and northwest of Guevavi Canyon, and on northern edge of map area in southern San Cayetano Mountains (fig. 1 and sheet 1). Along Santa Cruz River, lower part of formation unconformably overlies the Quartz Monzonite of Mount Benedict, and consists of well consolidated pale-red to light-brown conglomerate and conglomeratic sandstone; pebble, cobble, and some boulder-size clasts. Clasts and grains are subrounded and consist mostly of white porphyritic volcanic rocks, gray sandstone and siltstone, and granite; generally clast and grain supported, but contains some sand, silt, and clay matrix. In southern San Cayetano Mountains, unit consists mostly of pale-red to grayish-red conglomeratic quartzite, and greenish-gray thin-bedded argillite; intruded by numerous pale-red latite dikes and grayish-red rhyolitic to rhyodacite dikes and plugs (unit Tr) of Oligocene age (Simons, 1974). Drewes (1968) reported K-Ar age of 72.5 $\pm 2.2 \mathrm{Ma}$ (biotite) from a welded tuff in the Salero Formation in Santa Rita Mountains, $10 \mathrm{~km}$ north of the map area. Formation is at least 400 $\mathrm{m}$ thick in San Cayetano Mountains, and 50 to $150 \mathrm{~m}$ thick in the Santa Cruz River area

Quartz Monzonite of Mount Benedict (Jurassic) - Descriptions from Simons (1974)

Biotite-hornblende quartz monzonite - Light- to light-brownish-gray, coarse-grained, porphyritic quartz monzonite; 20 percent quartz, 36 percent plagioclase, 36 percent perthitic potassium feldspar, 4 percent biotite, 3 percent pale green hornblende, and 1 percent accessories; also contains some granodiorite and quartz diorite. K-Ar age on biotite $160 \pm 7 \mathrm{Ma}$, and on hornblende, $164 \pm 19 \mathrm{Ma}$ (Simons, 1974). Contains abundant northwest-trending lamprophyre, microdiorite, or diabase dikes of Jurassic age (Simons, 1974)

Quartz monzonite - Light brown and light gray, fine to coarse grained; abundant fine-grained or aplitic quartz monzonite at Mount Benedict, and epidote-quartz-chlorite rock (epidosite) north and east of Mount Benedict. Probably older than unit $\mathrm{Jb}$

Cretaceous and Jurassic rocks undivided - Cross section only; mostly includes Quartz Monzonite of Mount Benedict and equivalent units, but may also include some Cretaceous igneous and sedimentary rocks 


\section{Stratigraphy}

\section{Jurassic}

The oldest rocks exposed in the quadrangle include the Quartz Monzonite of Mount Benedict of Late to Middle Jurassic age (160 $\pm 19 \mathrm{Ma}$ and $164 \pm 19 \mathrm{Ma}$; Simons, 1974). These rocks are highly deformed and are intruded by numerous diorite and diabase dikes (Simons, 1974). The dikes are mostly northwest striking and southwest dipping, and although most are a few meters thick, some are as much as $60 \mathrm{~m}$ thick. We follow Simons (1974), and subdivided the formation into two units; biotite hornblende quartz monzonite $(\mathrm{Jb})$, the younger unit, and quartz monzonite (Jbm), the older unit. These rocks form a confining unit below the Miocene Nogales Formation and Quaternary to Tertiary basin-fill surficial deposits.

\section{Upper Cretaceous}

The lower part of the Upper Cretaceous Salero Formation unconformably overlies the Quartz Monzonite of Mount Benedict along the Santa Cruz River southeast of Sonoita Creek and northwest of Guevavi Canyon (sheet 1 and fig. 1). Most of the unit in that area consists of thick-bedded, wellconsolidated conglomerate and sandstone, with clasts of silicic volcanic rocks and some granite. The Salero Formation forms the high ridge of the San Cayetano Mountains on the north edge of the map, where it is greater than $400 \mathrm{~m}$ thick, and consists mainly of light-brown conglomerate and sandstone, green and gray argillite and sandstone, and pale red quartzite and conglomerate. These rocks are intruded by abundant west- to northwest-trending, reddish-gray latite dikes and plugs of Tertiary age. Drewes (1968) reported a $\mathrm{K}$-Ar age of $72.5 \pm 2.2 \mathrm{Ma}$ (biotite) from a welded tuff in the Santa Rita Mountains, about $10 \mathrm{~km}$ north of the map area, and Hayes (1970) reported that this K-Ar date combined with stratigraphic position indicates a late Campanian to earliest Maastrichtian age (about 72 to $69 \mathrm{Ma}$ ) for the formation.

\section{Tertiary}

\section{Grosvenor Hills Volcanics}

The Grosvenor Hills Volcanics (Drewes, 1968) are exposed north of Sonoita Creek and east of the San Cayetano Mountains, and consist mostly of pale red to pink rhyolite and rhyodacitic tuff, vitric lithic tuff, agglomerate, flow breccia, and latite. These rocks are well exposed north of the map area in the Grosvenor Hills, and age-equivalent rocks are exposed to the west in the Atascosa and Tumacacori Mountains, and to the south in the Nogales, Sonora area. Drewes $(1968,1972)$ subdivided the Grosvenor Hills into a basal gravel and silt, a moderately thick middle rhyolite member, and an upper rhyodacite member. The basal member is not exposed in the map area. Drewes $(1972,1980)$ reported ages from 28 to $27 \mathrm{Ma}$ for the Grosvenor Hills Volcanics, north of the map area in the Grosvenor Hills. Two samples collected from laccoliths intruding the rhyolite member had K-Ar ages (hornblende) of $27.8 \pm 2.8 \mathrm{Ma}$ and 27.6 Ma. The Grosvenor Hills were interpreted to be underlain by a thick, subsurface intrusion, based on a corresponding $10 \mathrm{~km}$-in-diameter, circular, positive magnetic anomaly (Gettings, 2002).

Drewes (1972) described the rhyolite member in the Grosvenor Hills to consist mostly of tuff and tuff breccia, with lesser amounts (about 5 percent each) of tuffaceous sandstone, agglomerate, lava flows, and welded tuff. Mapping by Drewes (1972) suggests these rocks were erupted from multiple vents. We collected samples from the rhyolite member of the Grosvenor Hills Volcanics in the map area north of Sonoita Creek (sheet 1). One sample from a rhyolitic to dacitic intrusive rock (sample 12SCB05, table 1) in the middle rhyolite member yielded ages of $27.8 \pm 0.3 \mathrm{Ma}$ (amphibole) and 27.6 $\pm 0.4 \mathrm{Ma}$ (biotite) (Cosca and others, 2013; table 1 and fig. 4). These ages are similar to those reported for the member by Drewes (1972).

Drewes (1972) reported the rhyodacite member to consist mostly of agglomerate and lava flows, with some welded tuff and minor non-welded tuff. Our new ${ }^{40} \mathrm{Ar} /{ }^{39} \mathrm{Ar}$ geochronology (table 1) indicates units of the upper rhyodacite member are significantly younger than originally interpreted by Drewes (28-27 Ma), and are about 27 to $23 \mathrm{Ma}$. These conclusions are based primarily on new ${ }^{40} \mathrm{Ar} /{ }^{39} \mathrm{Ar}$ geochronology ages determined for sanidine and biotite from rhyolite tuff samples, one ranging from $24.8 \pm 0.1 \mathrm{Ma}$ to $23.5 \pm 0.1 \mathrm{Ma}$ (sample $12 \mathrm{SCB} 03$, table 1), and another (sample 12SCB04, table 1) ranging from $26.9 \pm 0.2 \mathrm{Ma}$ to $26.3 \pm 0.7 \mathrm{Ma}$ (Cosca and others, 2013; table 1 and fig. 4). Additional evidence supporting a younger age for the upper rhyodacite member includes numerous detrital sanidine and plagioclase grains with ages ranging from about 26 to $23 \mathrm{Ma}$ in the overlying Proto Canyon and Nogales Wash members of the Nogales Formation (fig. 4; samples 11SCB01, $11 \mathrm{SCB} 02,11 \mathrm{SCB} 03,11 \mathrm{SCB} 08$, and 11SCB09 from the Nogales Wash member, and sample 12SCB01 from the Proto Canyon member). Additional studies are needed to better determine the geochronologic, stratigraphic, genetic, and tectonic relations between the middle and upper members, and with the onlapping members of the Nogales Formation.

\section{Nogales Formation}

The Nogales Formation was named by Simons (1974) for exposures in Nogales, Arizona, and areas to the east and north. In the Nogales area, the formation overlies the Jurassic Quartz Monzonite of Mount Benedict, which was a local source area for sediments in the formation. Simons (1974) recognized correlative sediments in the Sonoita Creek area that overlie the Grosvenor Hills Volcanics, which were a local source for detrital material in sediments of the Nogales Formation in that area. Because of the different source terrains for the formation, many of the clastic units commonly contain mixtures of Oligocene volcanic rocks and Jurassic 
Table 1. ${ }^{40} \mathrm{Ar} /{ }^{39} \mathrm{Ar}$ geochronology for Grosvenor Hills Volcanics and Nogales Formation in the Nogales and Rio Rico 1:24,000-scale quadrangles, Arizona. Data analyzed by Cosca and others (2013) at USGS Argon geochronology laboratory, Denver, Colorado. See combined ${ }^{40} \mathrm{Ar} /{ }^{39} \mathrm{Ar}$ data in appendix.

[Ma, age reported in mega-annums. UTM listed in northing and easting coordinates, zone 12]

\begin{tabular}{|c|c|c|c|c|c|}
\hline Sample & Geologic unit & Argon age & Material analyzed & \multicolumn{2}{|c|}{ UTM coordinates } \\
\hline 11SCB01 & Nogales Fm. & 25.09 to $23.6 \mathrm{Ma}$ & Sanidine, plagioclase & 3466868 & 505543 \\
\hline 11SCB02 & Nogales Fm. & 25.93 to $24.7 \pm 0.6 \mathrm{Ma}$ & Plagioclase & 3467200 & 506142 \\
\hline $11 \mathrm{SCB} 03$ & Nogales Fm. & 25.57 to $23.7 \mathrm{Ma}$ & Sanidine, plagioclase & 3467850 & 506764 \\
\hline $11 \mathrm{SCB} 07$ & Nogales Fm. & $11.67 \pm 0.09 \mathrm{Ma}$ & Whole rock & 3467793 & 509993 \\
\hline $11 \mathrm{SCB} 08$ & Nogales Fm. & $24.9 \pm 0.2 \mathrm{Ma}$ & Sanidine, plagioclase & 3466710 & 508185 \\
\hline 11SCB09 & Nogales Fm. & $25.2 \pm 0.7 \mathrm{Ma}$ & Sanidine, plagioclase & 3466814 & 508250 \\
\hline $12 \mathrm{SCB} 01$ & Nogales Fm. & $24.76 \mathrm{Ma}$ & Sanidine & 3470259 & 509952 \\
\hline $12 \mathrm{SCB} 03$ & Grosvenor Hills Volc. & $24.8 \pm 0.1$ to $23.5 \pm 0.1 \mathrm{Ma}$ & Biotite & 3483451 & 505870 \\
\hline 12SCB04 & Grosvenor Hills Volc. & $26.9 \pm 0.2$ to $26.3 \pm 0.7 \mathrm{Ma}$ & Amphibole & 3483522 & 506075 \\
\hline $12 \mathrm{SCB} 05$ & Grosvenor Hills Volc. & $27.8 \pm 0.3$ to $27.6 \pm 0.4 \mathrm{Ma}$ & Biotite, amphibole & 3483676 & 505884 \\
\hline
\end{tabular}
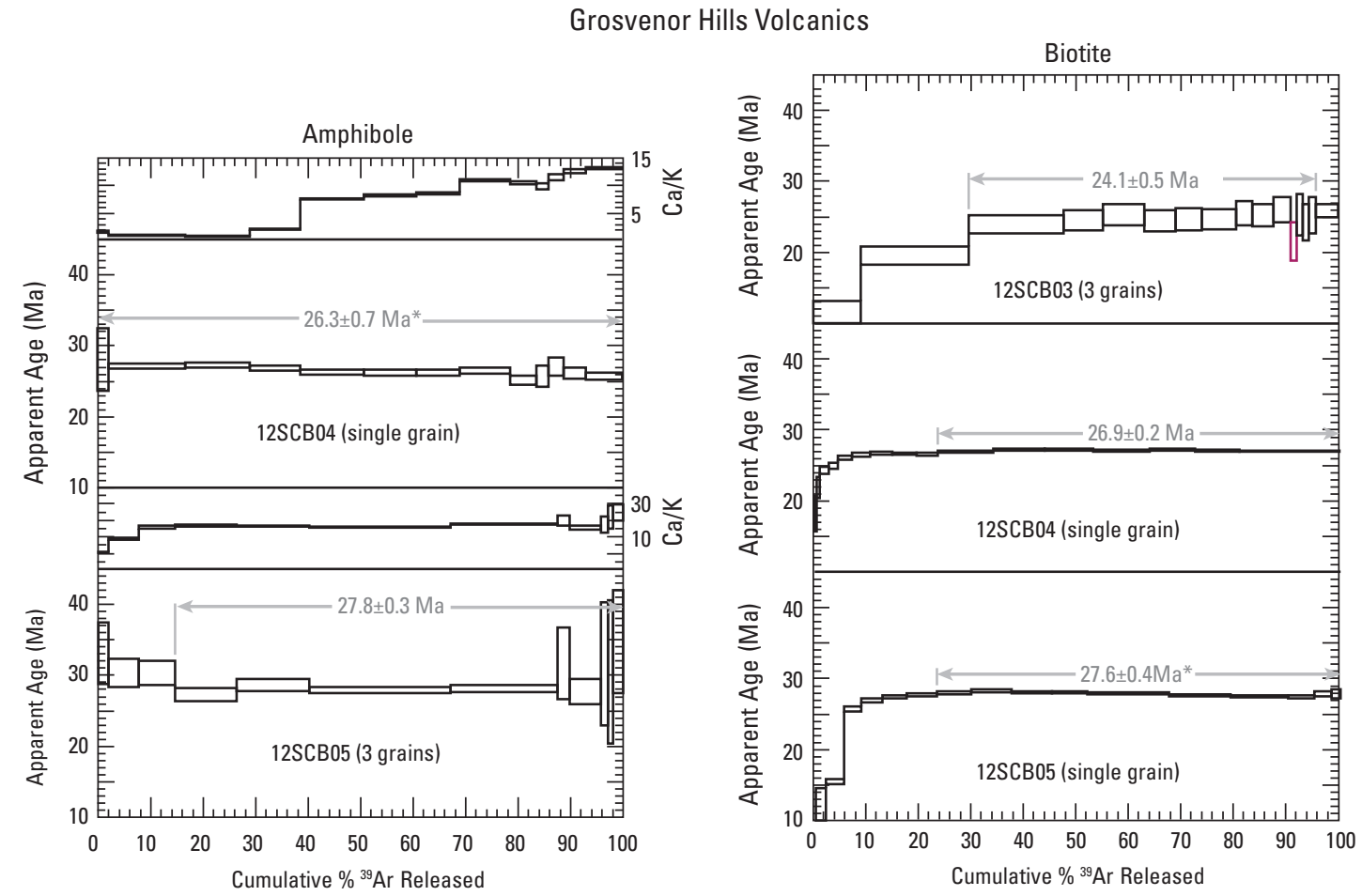

Figure 4. Plots of new ${ }^{40} \mathrm{Ar} /{ }^{39} \mathrm{Ar}$ geochronology incremental heating data for amphibole and biotite analyses from the Grosvenor Hills Volcanics. Incremental analysis indicated in red for sample 12SCB03 as omitted from calculation of plateau; number of grains analyzed for each sample indicated on plots. Apparent age reported in mega-annums (Ma); \%, percent.

monzonite. Simons estimated a thickness of about 2,290 $\mathrm{m}$ for the entire Nogales Formation, but our new mapping indicates a maximum thickness of about $950 \mathrm{~m}$ for the formation in the Nogales, Arizona area.

Simons (1974) originally subdivided the Nogales Formation in the Nogales area into lower, middle, and upper members, which are generally equivalent with the Mariposa, Nogales Wash, and Proto Canyon members in this report. Simons (1974) mapped his lower member mostly south of Mount Benedict, and reported that it contained conglomerate, fanglomerate, volcaniclastic conglomerate, sandstone, and tuff; thickness of the lower member was estimated to be about 1,500 m. Simons (1974) mapped his middle and upper members east of Nogales, Arizona, south of State Highway 82, and west of the Santa Cruz River; he described the middle member to consist of about $150 \mathrm{~m}$ of volcaniclastic conglomerate and sandstone and white biotite-hornblende tuff, and his upper member to consist of about $610 \mathrm{~m}$ of volcanic conglomerate with clasts of plutonic and metasedimentary rocks. The upper member contains basalt flows dated at $11.67 \pm 0.09 \mathrm{Ma}$ (Cosca and others, 2013). In the basin south of Sonoita Creek and east of the Mount Benedict fault, Simons (1974) mapped undivided Nogales Formation, that mostly contained volcanic conglomerate and sandstone which locally overlies the Grosvenor Hills Volcanics. 
Rocks of the Nogales Formation were mapped in other areas of the upper Santa Cruz basin. Drewes (1971) mapped the Nogales Formation near the mouth of Cottonwood Canyon in the northern Santa Rita Mountains (fig. 2), which he described as consisting mostly of gravel, conglomerate, and sand with abundant volcanic detritus. He described the unit as Miocene to Pliocene in age, and estimated its thickness to be slightly more than $300 \mathrm{~m}$. Lindsey and Van Gosen $(2005,2010)$ mapped the Nogales Formation in the Josephine Canyon area (fig. 2), south of Cottonwood Canyon. Cooper (1973) mapped the Nogales Formation in the southern Sierrita Mountains (fig. 2), where he noted volcaniclastic units in the lower $30 \mathrm{~m}$. Drewes (1980) mapped the Nogales Formation on the east flank of the Atascosa Mountains, in Agua Fria Canyon (fig. 2), where it was estimated to be about $800 \mathrm{~m}$ thick. In this area, the unit consists mostly of sandstone and conglomerate, with an ash-flow tuff near the base, and basalt flows in the middle and upper parts. Nelson (1963) mapped units of the Nogales Formation in the Walker and Peña Blanca Canyon areas (fig. 2), east of the Atascosa Mountains; he referred to these rocks as the "Peña Blanca Formation," which is about $110 \mathrm{~m}$ thick.

\section{Revised Stratigraphy for Nogales Formation}

New mapping for this report combined with geochronologic, geophysical, and hydrogeologic data, resulted in significant stratigraphic revision of the Nogales Formation as defined by Simons (1974), and recognizes three informal members, including (from base to top) the Proto Canyon, Nogales Wash, and Mariposa members. Sediments in the Nogales Formation were deposited mostly by streams and debris flows on alluvial fans on the flanks of the upper Santa Cruz basin, and in playas in axial parts of the basin. The depositional basin extends from west of the Patagonia Mountains, south of the Grosvenor Hills, west of the San Cayetano and Santa Rita Mountains, and east of the Atascosa and Tumacacori Mountains (fig. 2), and the basin extends southward into Sonora, Mexico. Basin geometry in the Nogales and Rio Rico quadrangles during the Miocene was complex due to a highly irregular pre-Nogales Formation erosion surface developed on Jurassic and Cretaceous intrusive and sedimentary rocks which were deformed by episodes of Miocene basin and range extension, and older pre-Tertiary deformational events, most notably Cretaceous plutonism and faulting related to the Laramide orogeny (Simons, 1974).

Within the map area, rocks of the Proto Canyon member represent initial deposits that accumulated in the southern part of the upper Santa Cruz basin, and were laid down across an area coincident with that of the modern day basin. During deposition of the Proto Canyon member, Mount Benedict (fig. 1, sheet 1) was likely a paleotopographic high near the center of the basin, based on coarse debris-flow conglomerate at the base of the Proto Canyon member shed off the flanks of Mount Benedict. The Mount Benedict horst block (fig. 1) likely stood topographically high in the basin owing to faulting during earlier stages of extension, or from some older
pre-Tertiary deformational events, or both. The horst block likely experienced multiple stages of uplift during deposition of the Nogales Formation based on unconformities bounding each member of the formation, and onlapping relations between the Proto Canyon member and the Nogales Wash and Mariposa members.

Uplift of the Mount Benedict horst block occurred during and/or following deposition of the Proto Canyon member to expose basal debris-flow conglomerate of the formation within the horst block, and further compartmentalized the southern part of the Santa Cruz basin into two main subbasins; one west of the horst block and east of the Atascosa and Tumacacori Mountains, and another east of the horst block and Santa Cruz River, south of the Grosvenor Hills, and west of the Patagonia Mountains. The Proto Canyon member was deeply eroded following this uplift, based partly on (1) the high degree of weathering of abundant Jurassic monzonite clasts contained within thick, arkose units in lower and middle parts of the member, and (2) the onlapping relations of the Nogales Wash and Mariposa members onto Proto Canyon member units in the southeastern part of the map area (fig. 5 and sheet 1). Further faulting and uplift of the horst block continued throughout and following deposition of the Nogales Formation, based on the observation that all members are highly deformed, and major faults cut the very oldest part of post-Nogales Formation alluvial basin-fill deposits (unit QTa) overlying the formation. Strata in all members of the Nogales Formation are moderately to highly rotated, with dips ranging from $10^{\circ}$ to $40^{\circ}$, and locally as much as $70^{\circ}$ along major faults (sheet 1 ). The formation is locally folded in the southeast part of the map near the international border, and in the central part of the map area west of the Gold Hill fault (fig. 1 and sheet 1).

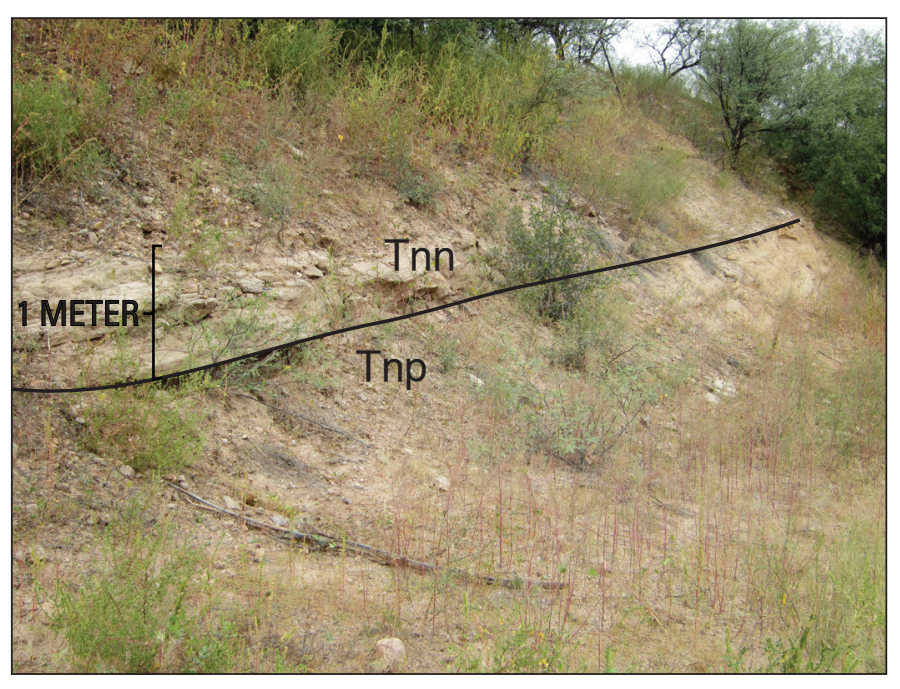

Figure 5. Northeast view of ledge-forming, resistant volcaniclastic sandstone beds in the Nogales Wash member of the Nogales Formation (Tnn) overlying less-resistant arkose sandstone and conglomerate beds in the lower part of the Proto Canyon member (Tnp), east of Nogales, Arizona, along State Highway 82. 


\section{Nogales Formation Geochronology}

Previous geochronology for the Nogales Formation was reported by Simons (1974), Marvin and others (1973), and Houser and others (2004). Simons (1974) reported a K-Ar age of 12.6 $\pm 0.8 \mathrm{Ma}$ (Marvin and others, 1973) on groundmass from a basalt in the Nogales Formation from Agua Fria Canyon, in the adjacent Peña Blanca Lake quadrangle (fig. 2). Houser and others (2004) indicated the presence of multiple generations of volcanic-sourced sanidine and plagioclase using ${ }^{40} \mathrm{Ar} /{ }^{39} \mathrm{Ar}$ geochronology, with the youngest grains providing an accurate determination of the age of Nogales Formation deposition. Houser and others (2004) dated two samples of the Nogales Formation in the upper Santa Cruz basin by single-grain, laserfusion ${ }^{40} \mathrm{Ar}{ }^{39} \mathrm{Ar}$ geochronology — one from Agua Fria Canyon, and one in Cottonwood Canyon (fig. 2). In Cottonwood Canyon, a tuff $30 \mathrm{~m}$ above the base of the formation yielded two possible ages of $15.53 \pm 0.38 \mathrm{Ma}$ (sanidine) and $17.38 \pm 0.77 \mathrm{Ma}$ (whole rock) (Houser and others, 2004). In the Agua Fria Canyon area, an ash-flow tuff near the basal contact of the formation yielded a weighted mean age of $13.23 \pm 0.10 \mathrm{Ma}$ determined from 14 sanidine grains (Houser and others, 2004).

New ${ }^{40} \mathrm{Ar} /{ }^{39} \mathrm{Ar}$ geochronology of the Nogales Formation (table 1) determined for this study generally supports these earlier geochronologic studies, and indicates the formation may be as old as early Miocene (about 20 to $18 \mathrm{Ma}$ ) and as young as early late Miocene (about $11 \mathrm{Ma}$ ). The minimum age limit of $11 \mathrm{Ma}$ is based on a whole-rock age of $11.67 \pm 0.09 \mathrm{Ma}$ (fig. 6; table 1) (Cosca and others, 2013), determined for a basalt in the Mariposa member, the upper member of the formation. Because the stratigraphic position of these basalts is in the lower part of the Mariposa member in the Nogales quadrangle, and to account for deposition of sediments in the upper part of the member, we estimated an overall minimum age of about $11 \mathrm{Ma}$ for the formation. Although our new ${ }^{40} \mathrm{Ar} /{ }^{39} \mathrm{Ar}$ age is the youngest age determined for the Nogales Formation, an older K-Ar age of 12.6 $\pm 0.8 \mathrm{Ma}$ (Marvin and other, 1973) was obtained from a basalt flow (whole rock) in the upper part of the formation in Aqua Fria Canyon (fig. 2). We dated two basalt samples from the Nogales Formation from Aqua Fria Canyon, possibly the same unit dated by Marvin and others (1973), and the basalts yielded ${ }^{40} \mathrm{Ar} /{ }^{39} \mathrm{Ar}$ plateau whole-rock ages of $13.64 \pm 0.11 \mathrm{Ma}$ and 13.65 $\pm 0.11 \mathrm{Ma}$ (Cosca and others, 2013; table 2 and fig. 6). These basalt ages are similar in age to the weighted mean age of 13.23 $\pm 0.10 \mathrm{Ma}$ age of sanidine ${ }^{40} \mathrm{Ar} /{ }^{39} \mathrm{Ar}$ fusion ages from the same area (Houser and others, 2004).

The maximum age of about 20 to $18 \mathrm{Ma}$ for the formation is based on the oldest age determinations for the formation in the upper Santa Cruz basin, in the Cottonwood Canyon area, where a sample collected in the basal $30 \mathrm{~m}$ of the formation yielded an age range between $17.38 \pm 0.77 \mathrm{Ma}$ (whole rock) and $15.53 \pm 0.38 \mathrm{Ma}$ (sanidine) (Houser and others, 2004). Further, new single-grain laser-fusion ${ }^{40} \mathrm{Ar} /{ }^{39} \mathrm{Ar}$ geochronology on four plagioclase grains from a rhyolite tuff in Agua Fria Canyon yielded a mean age of $18.4 \pm 1.5 \mathrm{Ma}$ (11SCB05; fig. 7; table 2) (Cosca and others, 2013). The large
Basalt in Mariposa member near U.S.-Mexico border
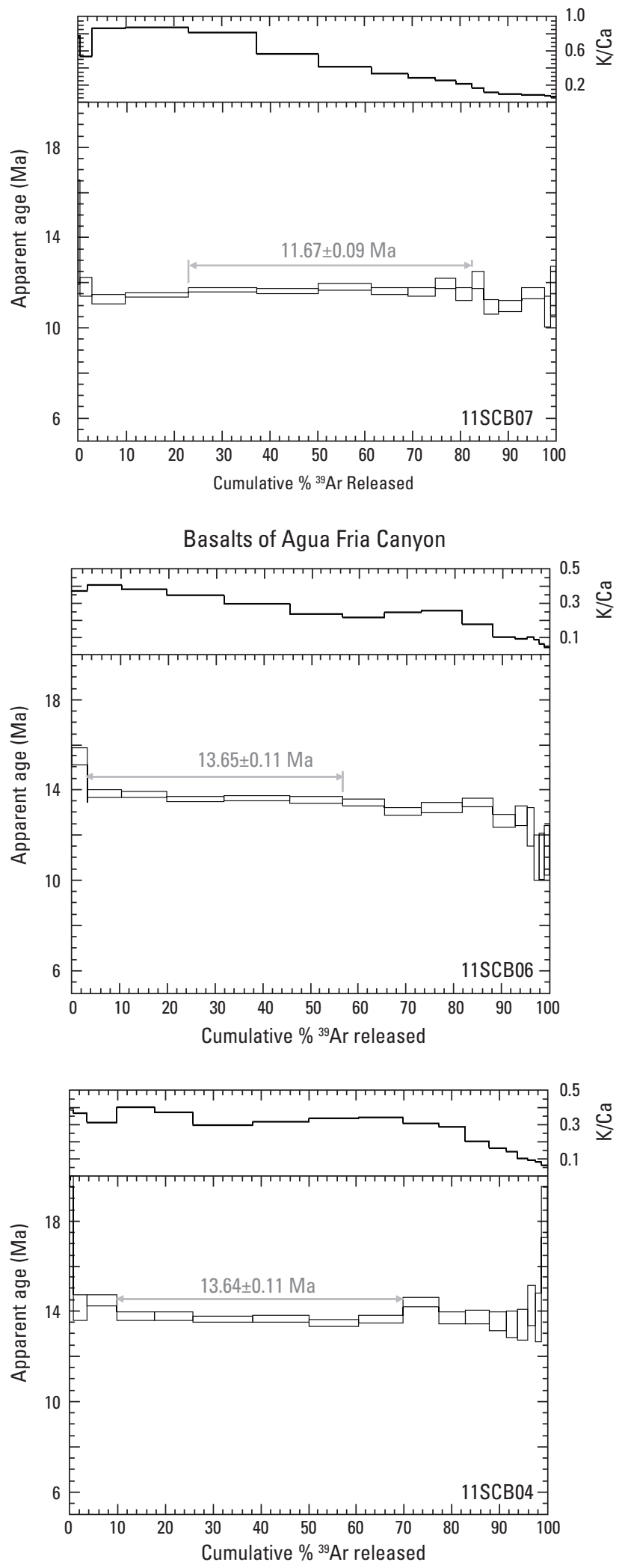

Figure 6. Plots of new ${ }^{40} \mathrm{Ar} /{ }^{39} \mathrm{Ar}$ incremental-heating analyses of whole-rock samples from basalts in the Nogales Formation. Apparent age reported in mega-annums (Ma); \%, percent. 
Table 2. ${ }^{40} \mathrm{Ar} /{ }^{39} \mathrm{Ar}$ geochronology for Nogales Formation in the Agua Fria Canyon area (fig. 2), Peña Blanca Lake 1:24,000-scale quadrangle, adjacent and to the west of the Rio Rico quadrangle. Data analyzed by Cosca and others (2013) at USGS Argon geochronology laboratory, Denver, Colorado; see combined ${ }^{40} \mathrm{Ar} /{ }^{39} \mathrm{Ar}$ data in appendix.

[UTM listed in northing and easting coordinates, zone 12]

\begin{tabular}{clllc}
\hline Sample & Geologic unit & \multicolumn{1}{c}{ Argon age } & \multicolumn{1}{c}{ Material analyzed } & UTM coordinates \\
\hline 11SCB04 & Nogales Fm. & $13.64 \pm 0.11 \mathrm{Ma}$ & whole rock & 3480096 \\
11SCB05 & Nogales Fm. & $18.4 \pm 1.5 \mathrm{Ma}$ & sanidine, plagioclase & 3480019 \\
11SCB06 & Nogales Fm. & $13.65 \pm 0.11 \mathrm{Ma}$ & whole rock & 495337 \\
\hline
\end{tabular}

A Sanidine from rhyolite tuff in Grosvenor Hills Volcanics

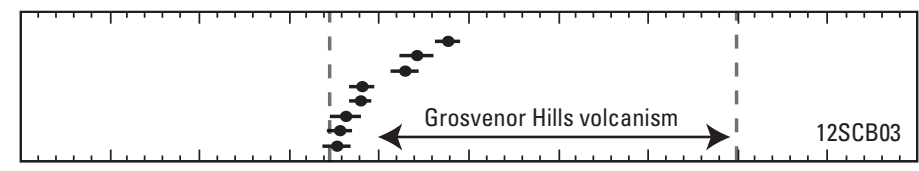

B Detrital sanidine and plagioclase in fluvially reworked volcaniclastic sediments of the Nogales Formation

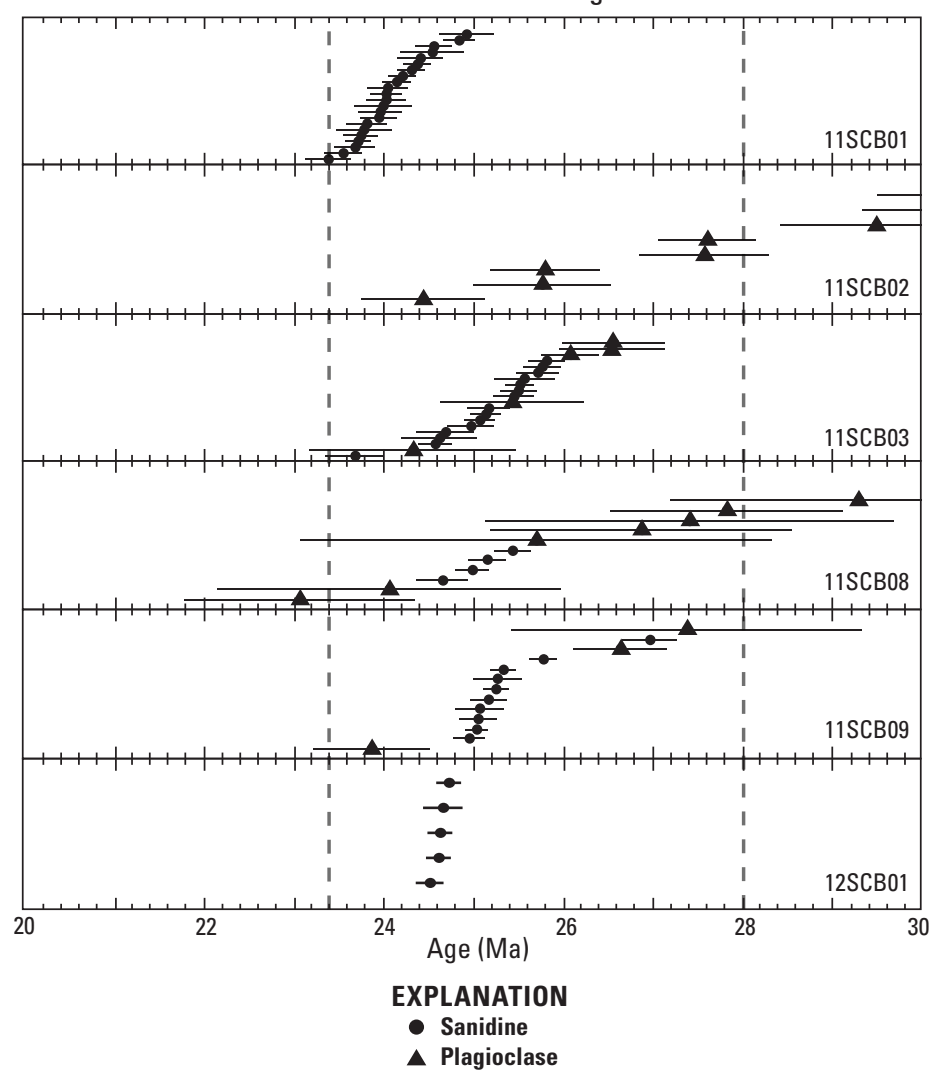

C

Sanidine and plagioclase from rhyolite tuff in Nogales Formation in Agua Fria Canyon

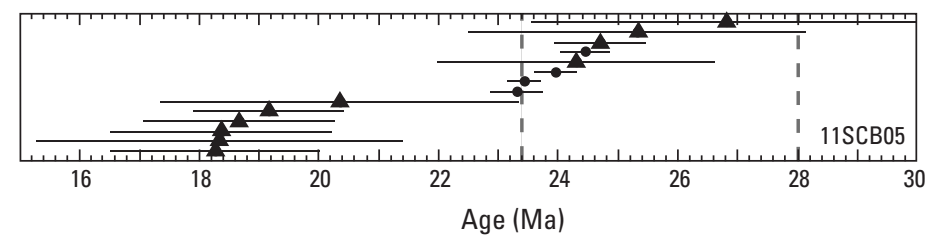

Figure 7. $\mathrm{New}^{40} \mathrm{Ar} /{ }^{39} \mathrm{Ar}$ ideogram plots for laser-fusion analyses of $A$, sanidine from rhyolite tuff in Grosvenor Hills Volcanics, $B$, detrital sanidine and plagioclase from volcaniclastic sediments in the Nogales Formation, and $C$, sanidine and plagioclase from rhyolite tuff in the Nogales Formation from Agua Fria Canyon area. Age reported in mega-annums (Ma). 
analytical uncertainties associated with all of these analyses support any age between 20 and $16 \mathrm{Ma}$ for the maximum age of the Nogales Formation, thus their usefulness for precise geochronology is limited.

Single-grain, laser-fusion ${ }^{40} \mathrm{Ar} /{ }^{39} \mathrm{Ar}$ geochronology on detrital sanidine and plagioclase from the Proto Canyon and Nogales Wash members of the Nogales Formation for this study yielded ages ranging from 26 to $23 \mathrm{Ma}$ (table 1), which likely reflect the ages of the Grosvenor Hills Volcanics (fig. 7) or equivalent rocks from an unknown source in Sonora. Detrital sanidine grains from the Proto Canyon member yielded a ${ }^{40} \mathrm{Ar} /{ }^{39} \mathrm{Ar}$ age of $24.76 \mathrm{Ma}$ (table 1, sample 12SCB01). Several samples from the Nogales Wash member (table 1; samples 11SCB01, 02, 03, 08, and 09) yielded ${ }^{40} \mathrm{Ar} /{ }^{39} \mathrm{Ar}$ ages from 26 to $23 \mathrm{Ma}$. The restricted age range of volcanic feldspars closely matches the age of volcanism in the Grosvenor Hills, the presumed source area for these grains (fig. 7).

\section{Proto Canyon Member}

The lower member of the Nogales Wash Formation is herein informally named for exposures in Proto Canyon, in the southeastern part of the map area (fig. 1, sheet 1). South of Mount Benedict (fig. 1), the basal part of the Proto Canyon member consists of distinctive debris-flow conglomerate (fig. 8) which grades upward into arkose conglomerate and sandstone (fig. 9). The basal coarse debris-flow conglomerate consists entirely of monzonite clasts, is primarily clastsupported (fig. 8), and is well exposed near the contact with the Jurassic monzonite. These beds grade upward into distinctive weakly consolidated sequences of pale-reddish-brown arkose conglomerate and sandstone, with some beds of poorly

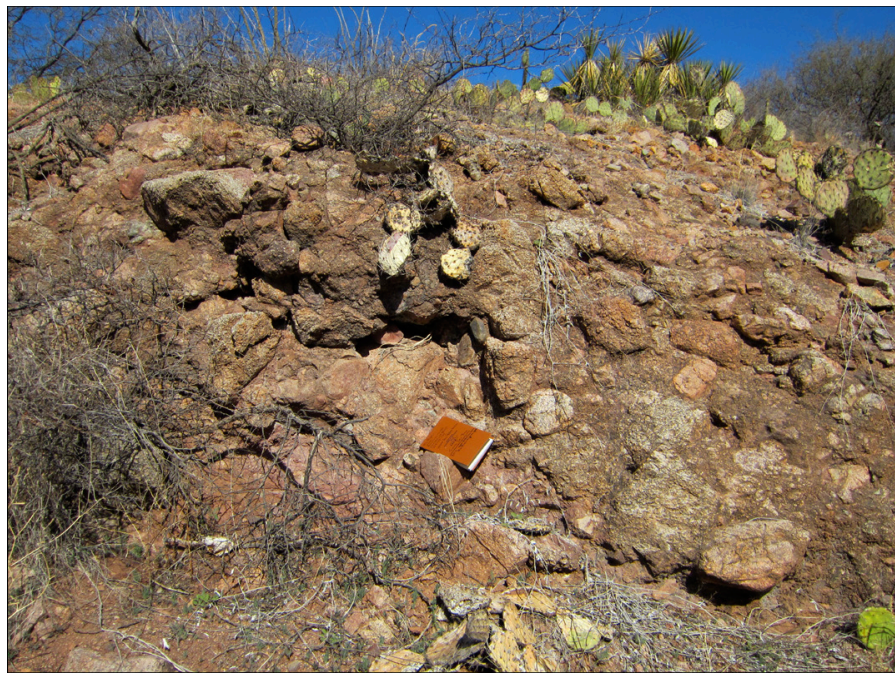

Figure 8. Basal debris-flow conglomerate in the Proto Canyon member of the Nogales Formation south of Mount Benedict, near contact with Jurassic Quartz Monzonite of Mount Benedict. Conglomerate is mostly clast-supported and well consolidated; notebook for scale.

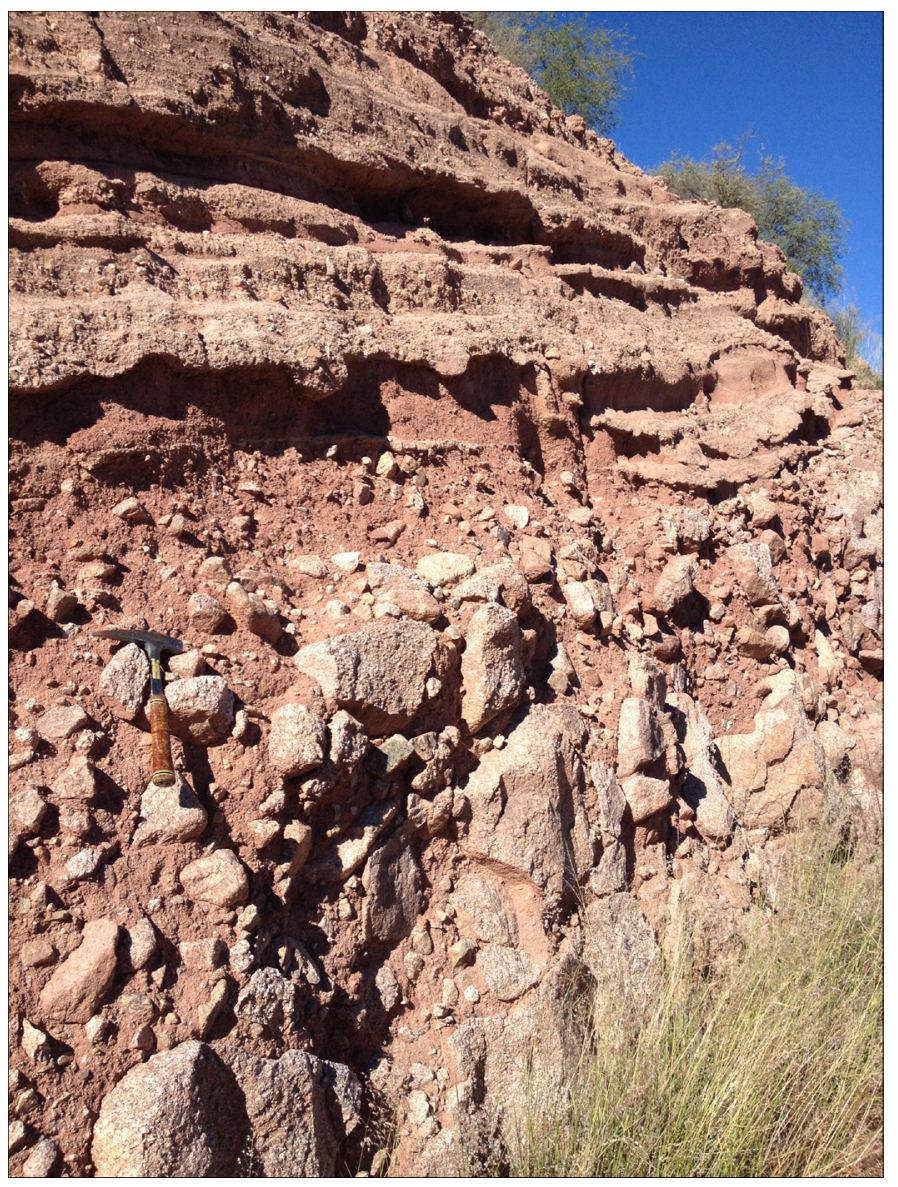

Figure 9. Sequence of alternating beds of arkosic sandstone, conglomeratic sandstone, and debris-flow conglomerate in lower parts of Proto Canyon member, above basal debris-flow conglomerate; hammer in middle left for scale.

sorted debris-flow conglomerate with subangular, monzonite boulders, cobbles, and pebbles, in a mostly sandy matrix (fig. 9). Unlike most all other units in the Nogales Formation, the basal debris flow conglomerate and arkose units characteristically lack pumice and altered volcanic glass fragments, and consist almost entirely of monzonite detritus eroded from the Quartz Monzonite of Mount Benedict. The basal debris-flow conglomerate and arkose units are well exposed in the basin north of Proto Canyon and State Highway 82, and south of Mount Benedict. The thickness of the basal debris-flow conglomerate and arkose units combined is variable, but estimated at about 100 to $250 \mathrm{~m}$ thick.

The lower units of the Proto Canyon member above the basal conglomerate and arkose units are exposed in Proto Canyon south of State Highway 82, where they consist of cliff-forming, fining-upward, cyclic fluvial sequences of volcaniclastic conglomerate at the base, volcaniclastic conglomeratic sandstone in the middle, and laminated white, water-lain pumice siltstone at the top (fig. 10); the sequences also contain some debris flow conglomerate beds. The middle part of the Proto Canyon Member contains alternating beds 


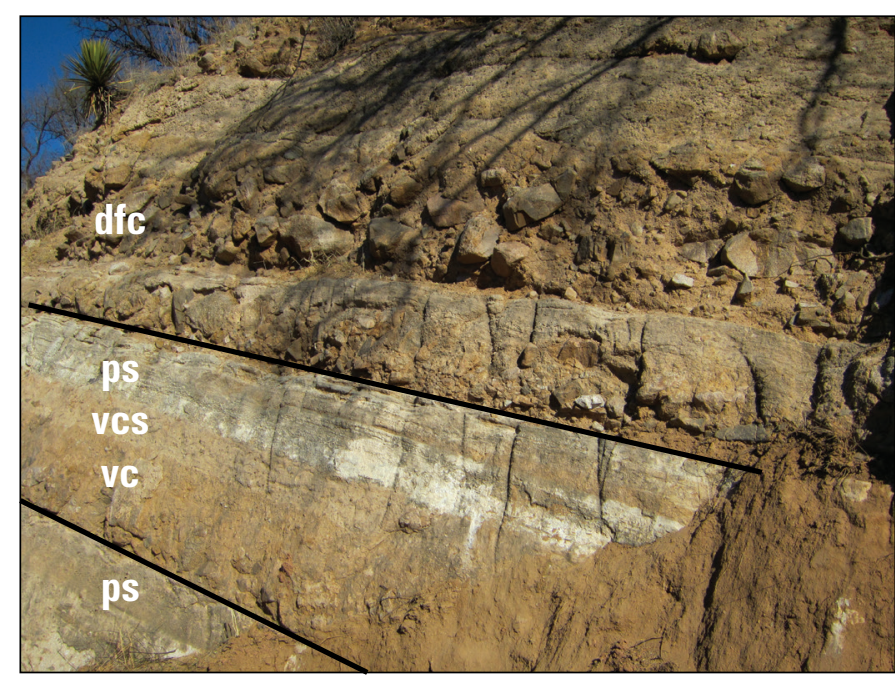

Figure 10. Cliff-forming, cyclic, fining-upward, fluvial sequences in lower part of the Proto Canyon member exposed in Proto Canyon. Depositional cycles (one complete cycle, about $1.0 \mathrm{~m}$ thick, outlined by black lines) generally consist of (from base to top) volcaniclastic conglomerate (vc); volcaniclastic conglomeratic sandstone (vcs); and overlying white horizontally bedded pumice siltstone (ps) (center of photograph). Sequences also contain some debris-flow conglomerate (dfc) beds.

of thin-bedded yellowish-gray volcaniclastic sandstone and conglomeratic sandstone, interbedded red and gray sandy claystone (fig. 11), and red arkosic, clayey and sandy conglomerate, best exposed in the Yerba Buena Canyon area (fig. 1). Claystone samples and clay-fraction samples from arkosic conglomerate in the area contain abundant kaolinite, formed primarily by the weathering of feldspar sourced from the Quartz Monzonite of Mount Benedict. This clay mineral assemblage is in contrast to those of most other claystones and clay-fraction samples from volcaniclastic sandstone in the formation, especially those in the Mariposa member, which contained greater amounts of smectite and illite, the zeolite clinoptilolite, and minor amounts to no kaolinite.

The upper part of the Proto Canyon member consists mainly of pinkish-gray to yellowish-gray, mostly poorly sorted, volcaniclastic sandstone and conglomerate (figs. 12 and 13) exposed in the Grand Avenue area, north of Mariposa Road. The sandstone and conglomerate beds in the upper part of the member are similar in appearance to clastic units in the Nogales Wash member of the Nogales Formation, but the Proto Canyon member units are generally thinner bedded and have abundant monzonite clasts, reflecting locally derived detritus from the Quartz Monzonite of Mount Benedict in the Mount Benedict horst block.

The thickness of the Proto Canyon member is highly variable, but maximum thickness is about $450 \mathrm{~m}$. The variability in thickness is due to structural deformation combined with deep erosion of the member prior to deposition of the overlying Nogales Wash and Mariposa members. The Proto Canyon member is mostly exposed in the topographically high hills of the Mount Benedict horst block east of the Nogales

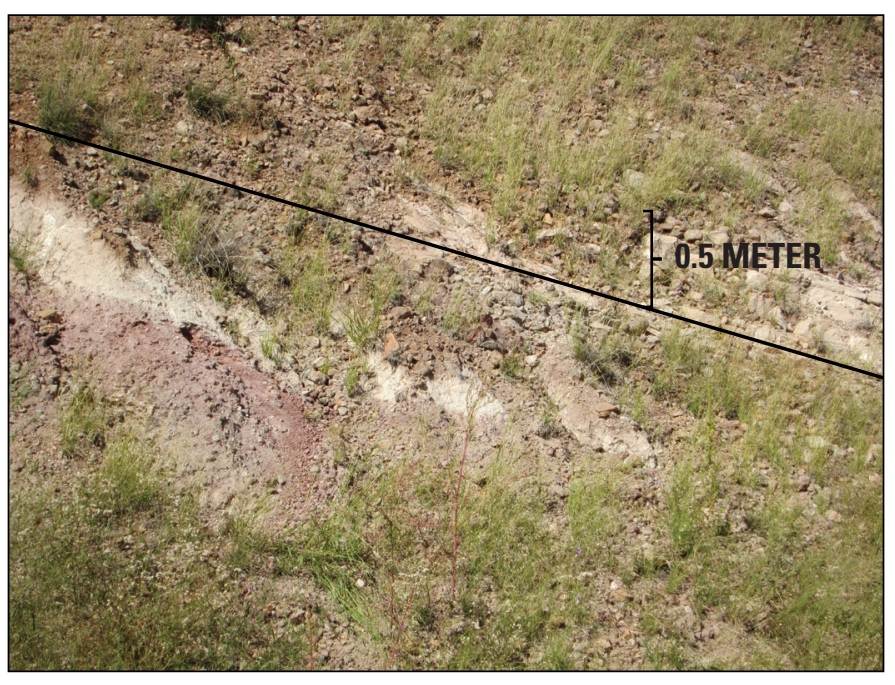

Figure 11. Red and light-gray gravelly claystone (below black line) and overlying gray volcaniclastic sandstone (above black line) in the middle part of the Proto Canyon member exposed in Yerba Buena Canyon. Exposed part of gray sandstone bed above black line at far right is about $0.5 \mathrm{~m}$ thick.

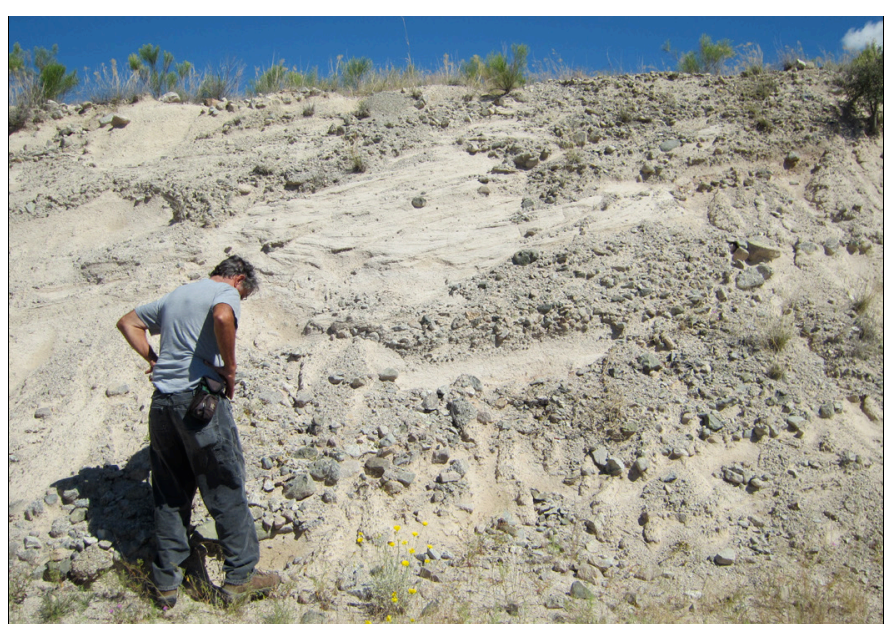

Figure 12. Fluvial cross-bedded volcaniclastic sandstone and conglomerate with lag monzonite gravel in channels, in upper part of the Proto Canyon member exposed west of Grand Avenue, and north of Mariposa Road.

urban area, and west of the Santa Cruz River, and from Proto Canyon southeastward to across the international border (sheet 1). Rocks of the Proto Canyon member are also exposed in northeast Nogales, Sonora; the northern extent of outcrop crosses into the U.S. just east of downtown Nogales, where it flanks Cretaceous diorite (map unit Kd) (sheet 1). Other exposures of the Proto Canyon member are in the Sonoita Creek area, where the member laps onto the Grosvenor Hills Volcanics. In this area, the lower part of the member is pinkish-gray, cliff- to ledge-forming, poorly sorted volcaniclastic conglomerate and sandstone containing clasts and grains composed of mostly white and red porphyritic volcanic rocks, brownish-gray rhyodacite (fig. 14), and some pumice and latite 


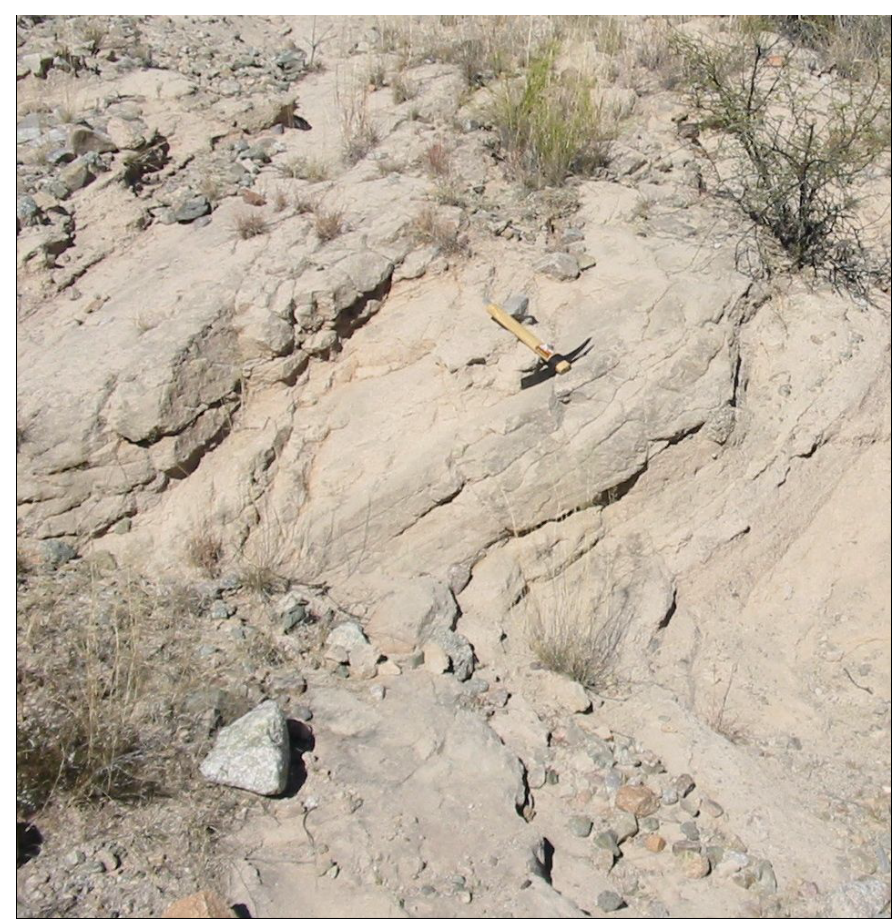

Figure 13. Pinkish-gray volcaniclastic sandstone in the uppermost part of the Proto Canyon member, exposed north of Mariposa Road, between Interstate 19 and Grand Avenue; pick in middle for scale.

derived from the Grosvenor Hills Volcanics. The upper part of the member is a sequence of mostly thin-bedded, fine-grained, moderately sorted, volcaniclastic sandstone and conglomeratic sandstone, which weathers to form distinctive rounded ledges.

\section{Nogales Wash Member}

The middle member of the Nogales Formation is herein informally named the Nogales Wash member, for exposures in the Nogales Wash area, south of Mariposa Road (sheet 1). The member is only present in the southern part of the map area, and outcrops extend from Ephraim Canyon on the west, to about $4 \mathrm{~km}$ east of Grand Avenue (sheet 1 and fig. 1). The member typically contains ledgy to massive cliff-forming, yellowishgray to pinkish-gray, volcaniclastic conglomerate and sandstone with abundant pumice fragments, and it generally lacks claystone beds unlike the other two members of the formation. Outcrops of the member are pervasively fractured in the map area. The Nogales Wash member is unconformable with the Proto Canyon member, and laps onto the latter member along State Highway 82, about $1.5 \mathrm{~km}$ northeast of Grand Avenue (fig. 5; sheet 1). The Nogales Wash member is about 30 to $80 \mathrm{~m}$ thick in scattered outcrops in the urban Nogales area, but it is estimated to be as much as $150 \mathrm{~m}$ thick, based on the subsurface projection of surface unit exposures shown in cross sections $E-E^{\prime}$ and $F-F^{\prime}$ (sheet 2). The basal 20 to $30 \mathrm{~m}$ of the member contains distinctive massive cliffs of yellowish-gray to pinkishgray, moderately consolidated volcaniclastic sandstone and conglomeratic sandstone (fig. 15). Most other parts of the member contain alternating beds of thin- to thick-bedded, volcaniclastic sandstone and conglomeratic sandstone (fig. 16), which locally display tabular-planar cross-bedding. Limitation of the member to the southern part of the map area, combined with onlapping relations with the lower Proto Canyon member, suggest the Nogales Wash sediments were deposited in a paleo-valley eroded into the Proto Canyon member, coincident with modernday Nogales Wash.

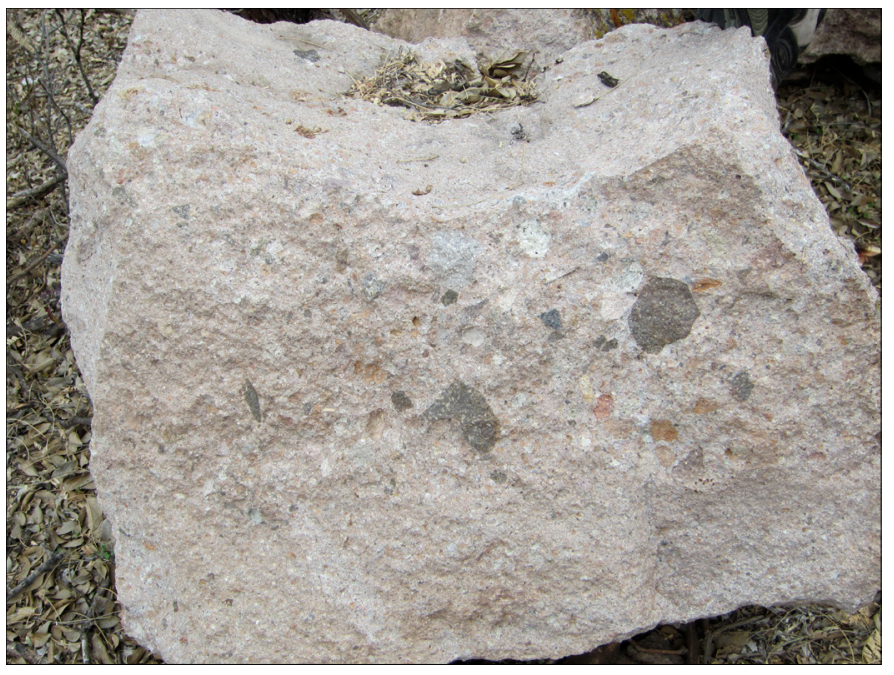

Figure 14. Boulder of Proto Canyon member exposed in Sonoita Creek area where it laps onto the Grosvenor Hills Volcanics; unit in lower part of member and consists of volcaniclastic conglomerate with clasts mostly of white and red porphyritic volcanic rocks, and brownish-gray rhyodacite derived from the Grosvenor Hills Volcanics; boulder is about $0.5 \mathrm{~m}$ in diameter.

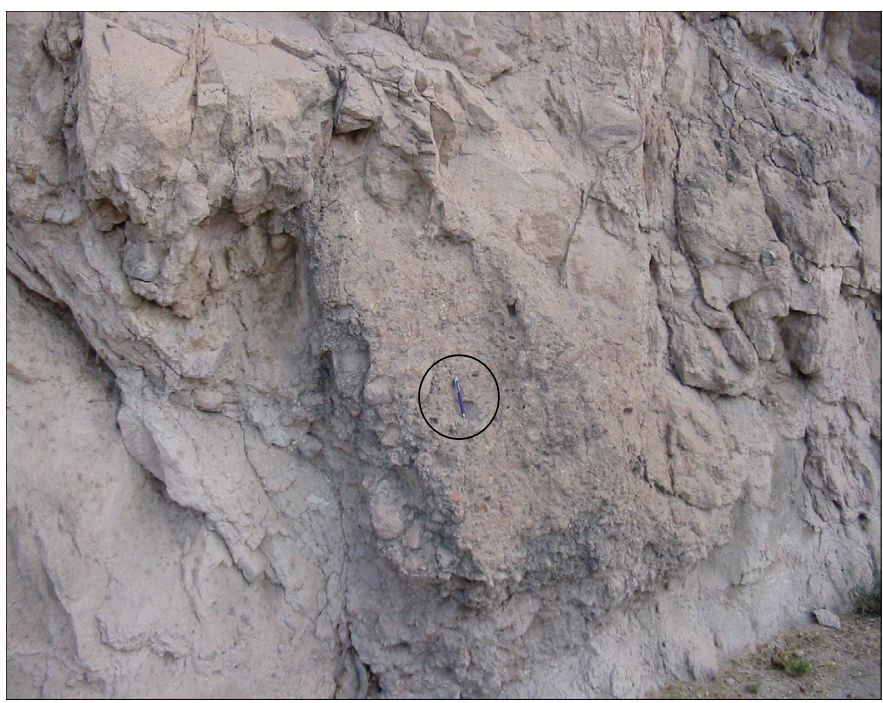

Figure 15. Massive, cliff-forming volcaniclastic sandstone and conglomeratic sandstone in the basal part of the Nogales Wash member along Grand Avenue, south of Mariposa Road. Note internal deformation including abundant fractures, and breccia zone (center of photograph), indicating syndepositional extensional tectonism. Pen in circle for scale. 


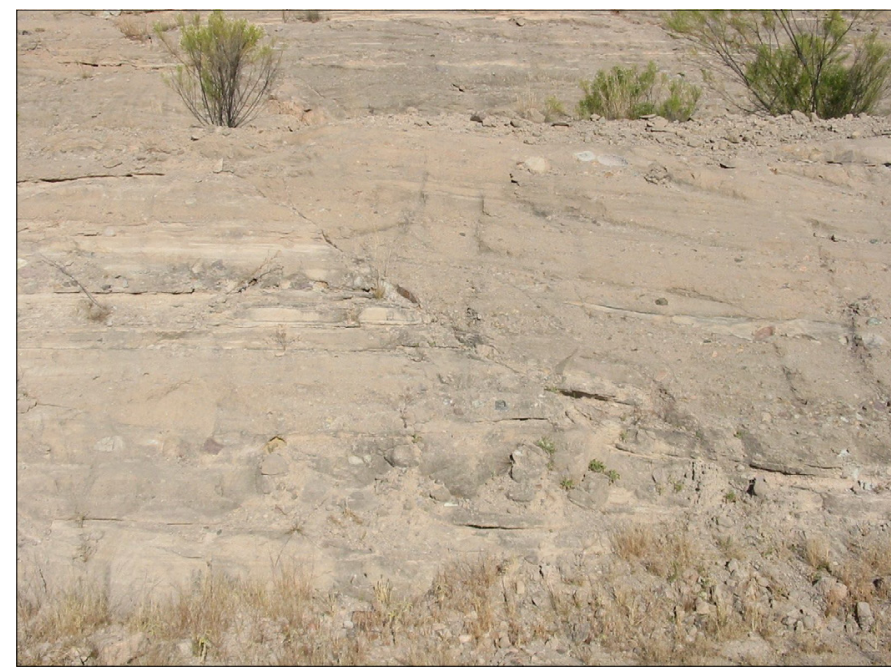

Figure 16. Alternating thin- to thick-bedded, volcaniclastic sandstone and conglomeratic sandstone of the Nogales Wash member south of Mariposa Road and west of Grand Avenue; smalldisplacement fault diagonally cuts beds in center of photograph. Height of shrub in upper left is about $0.6 \mathrm{~m}$.

It is unclear whether units equivalent to the Nogales Wash member are present in the subsurface in the northern part of the map area, either in (1) the basin west of Nogales Wash or (2) the basin south of Sonoita Creek and east of the Santa Cruz River. However, several map relations suggest the member may be absent in those basins. In the basin west of Nogales Wash, the northernmost outcrops of the Nogales Wash member are just south of Mariposa Road and east of Grand Avenue (sheet 1). These relations indicate the member onlaps the Proto Canyon member, and pinches out north of Mariposa Road, as it does to the east along Highway 82. In addition, south of Mariposa Road, the Mariposa member is faulted against the Nogales Wash member along the Grand Avenue fault, whereas north of Mariposa Road, the Mariposa member is faulted against the Proto Canyon member, indicating the Mariposa member directly overlies the Proto Canyon member in the subsurface, where the Nogales Wash member has pinched out. Map evidence indicating the Nogales Wash member is absent in the basin south of Sonoita Creek and east of the Santa Cruz River includes an angular unconformity between the Mariposa member and the Proto Canyon member just south of Sonoita Creek, and the Nogales Wash member is apparently absent. More subsurface information (drill hole data) and surface stratigraphic data are needed to further evaluate these preliminary conclusions.

\section{Mariposa Member}

The upper member of the Nogales Formation is herein informally named the Mariposa member, for outcrops north and south of Mariposa Road, between Interstate 19 and Grand
Avenue (sheet 1). The member is also exposed in southeastern parts of the map area, and in the basin south of Sonoita Creek and east of the Santa Cruz River (sheet 1). The Mariposa member generally has more pinkish-red color tones compared to dominant yellowish-gray tones in the Nogales Wash member, is less consolidated than the Nogales Wash member, and is more calcareous than the other two members of the formation. North of Mariposa Road along Interstate 19, the member consists of alternating beds of pale-red to pinkish-gray, coarseto fine-grained, volcaniclastic conglomeratic sandstone,

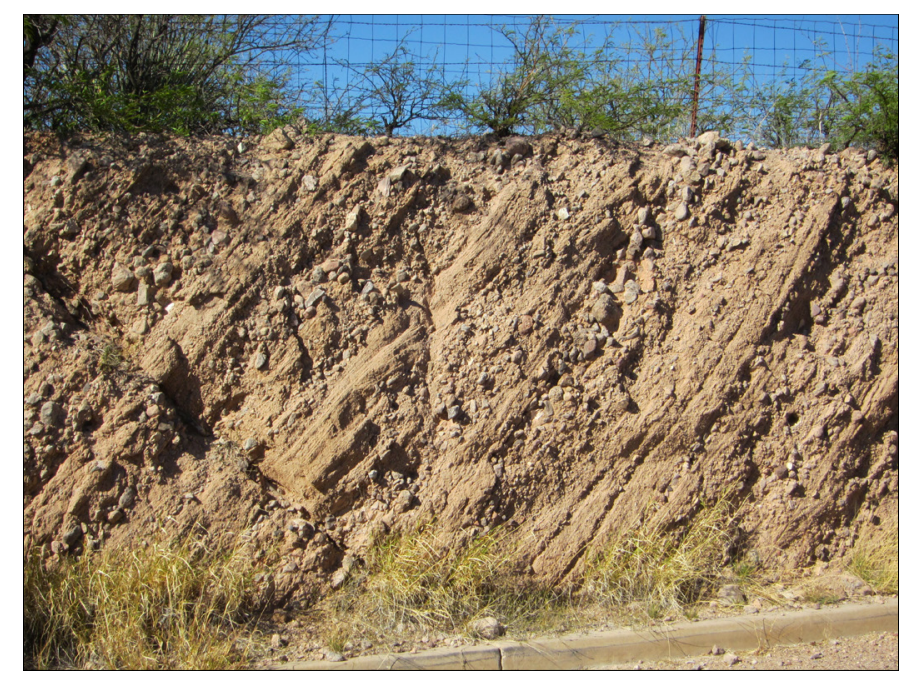

Figure 17. Faulted and highly rotated beds (dipping $48^{\circ}$ northwest) of Mariposa member along Interstate 19, north of Mariposa Road. Beds consist of alternating volcaniclastic conglomeratic sandstone, sandstone, and minor siltstone. Height of concrete curb in lower right is about $0.15 \mathrm{~m}$.

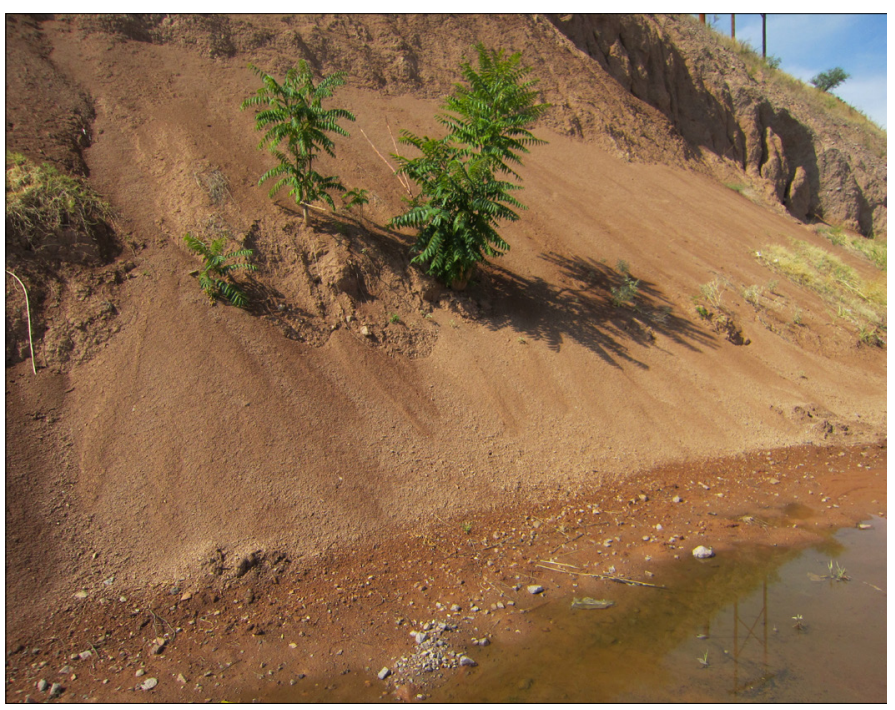

Figure 18. Massive claystone unit in Mariposa member exposed south of Mariposa Road, between Interstate 19 and Grand Avenue. Height of walnut shrub in center of photograph is about $1.5 \mathrm{~m}$. 
sandstone, and minor siltstone (fig. 17). South of Mariposa Road between Interstate 19 and Grand Avenue, a massive claystone unit (fig. 18) likely represents playa deposits in an axial-basin facies of the member, based on its fine-grained character. X-ray diffraction analyses were conducted on several samples from this unit, and results indicated the claystone contained abundant mixed-layer smectite and illite, and varying amounts of the zeolite clinoptilolite. About 30 to $40 \mathrm{~m}$ of the claystone unit is exposed, but total thickness may be $60 \mathrm{~m}$ or more, indicating the unit may locally be a significant confining unit. More subsurface data are needed to determine the claystone's lateral extent and thickness in the basin. No evaporite deposits were noted in the claystone, which may indicate the Miocene Nogales basin was not a closed basin; however, evaporites may be preserved at lower stratigraphic levels in axial parts of the basin, like those noted in drill holes in the Tucson basin (fig. 2), north of the map area (Houser and others, 2004).

The Mariposa member is also exposed in the southeastern part of the map area (sheet 1), southeast of highway 82 and north of the international border, where lower parts of the member consist mostly of volcaniclastic, pebble conglomerate and sandstone, and some fine-grained, moderately sorted sandstone. In this area, clasts are mostly subangular, lightbrownish-gray rhyolite that may be derived from an unidentified volcanic source likely in northeastern Nogales, Sonora. The member here also contains small discontinuous basalt flows which are about 2 to $5 \mathrm{~m}$ thick, and a sample from one flow dated near the international border yielded a ${ }^{40} \mathrm{Ar} /{ }^{39} \mathrm{Ar}$ geochronology plateau age of $11.67 \pm 0.09 \mathrm{Ma}$ (whole rock) (fig. 6; table 1; Cosca and others, 2013); this date provides a minimum age for the Nogales Formation.

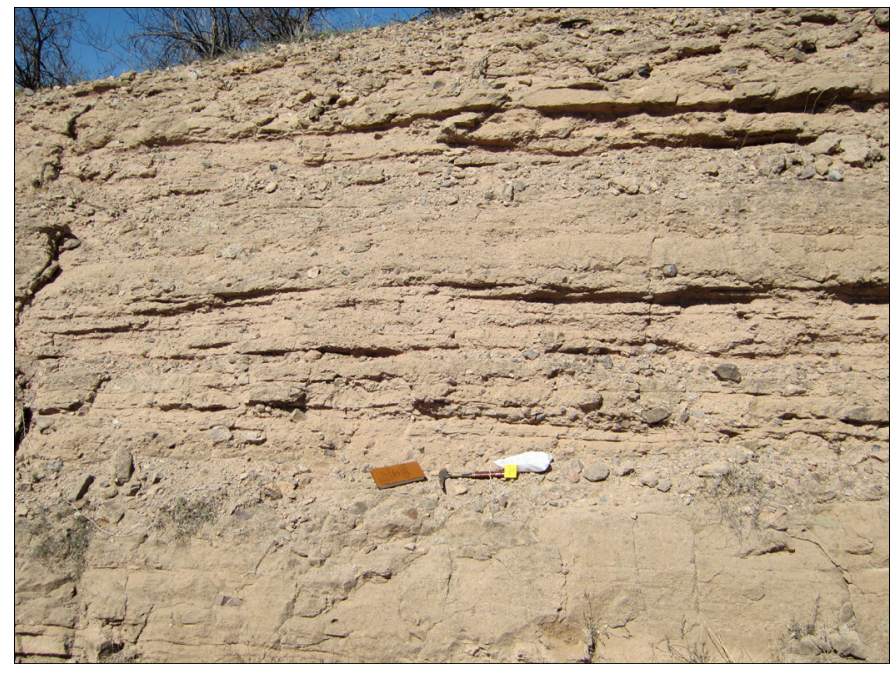

Figure 19. Mariposa member in basin south of Sonoita Creek and east of the Santa Cruz River, composed of alternating beds of volcaniclastic conglomeratic sandstone, sandstone, and few thin silt and clay partings; hammer and field notebook for scale.
In the basin south of Sonoita Creek and east of the Santa Cruz River, the Mariposa member contains pinkish-gray, alternating beds of volcaniclastic conglomeratic sandstone, sandstone, and some siltstone and claystone (fig. 19), like in the Mariposa Road type area, but units are generally thinner bedded and finer-grained than those in the type area, and consist mostly of alternating beds of fine-grained volcaniclastic sandstone, siltstone, and claystone (fig. 20). The Mariposa member is this area also contains claystone units similar to those in the Mariposa Road type area, (fig. 21), but these units are thinner than those in the type area, range from about 0.5 to $3 \mathrm{~m}$ thick, and are generally interbedded with volcaniclastic sandstone beds.

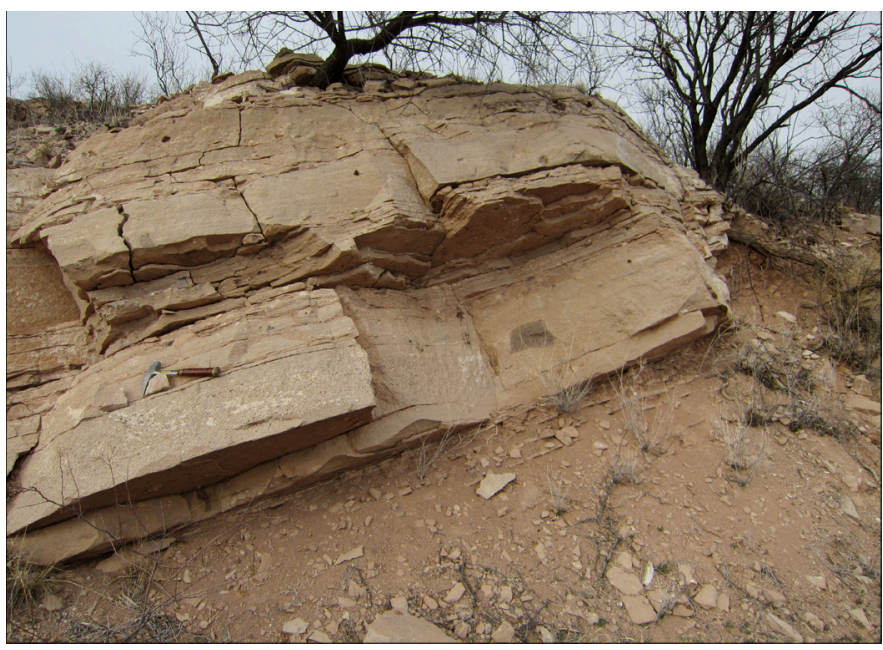

Figure 20. Fine-grained facies of the Mariposa member in basin south of Sonoita Creek and east of the Santa Cruz River, composed of alternating beds of fine-grained volcaniclastic sandstone, siltstone, and claystone; hammer in lower left for scale.

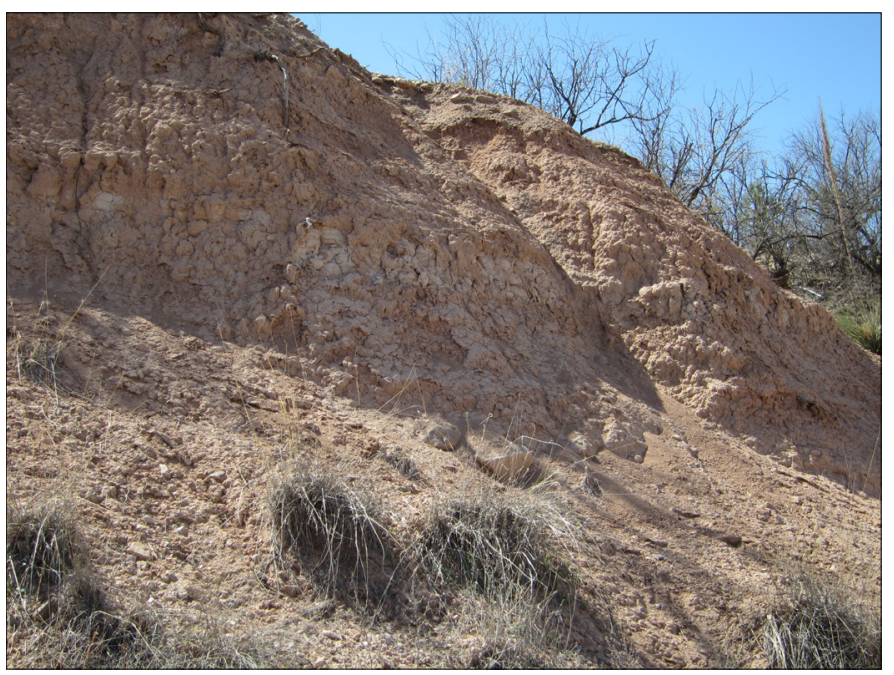

Figure 21. Sandy and gravelly claystone beds in the Mariposa member south of Sonoita Creek and east of the Santa Cruz River; height of outcrop about $3 \mathrm{~m}$. 


\section{Late Tertiary to Early Pleistocene Basin-Fill Deposits}

Basin fill refers to a relatively thin (generally $\leq 100 \mathrm{~m}$ ) sequence of alluvial deposits that unconformably overlies a variety of Tertiary strata (including Nogales Formation sediments and the Grosvenor Hills Volcanics), as well as many older bedrock units that are exposed in dissected basins in the western, north-central, and east-central parts of the map area. Basin-fill deposits typically represent the youngest set of aerially extensive sediments that are in turn locally overlain by thin and spatially restricted veneers of ridge-capping and inset Quaternary surficial deposits described elsewhere in this report. Basin-fill deposits consist of a reddish-brown to pinkish-gray, moderately to poorly bedded, and weakly consolidated sequence of interstratified gravelly sand and sandy gravel (figs. 22 and $23)$. The sediments typically display provenance relations and stratal dips consistent with fan deposition sourced from nearby highland bedrock source terrains. The absence of strongly rotated bedding, faults, or fractures in most exposures of basinfill deposits indicates no significant post-depositional deformation in most of these deposits. The primary exceptions are local outcrops of basal sections of basin fill that exhibit low to moderate structural rotation and widely spaced internal faults and fractures near the traces of exposed basin-bounding faults. Basin fill can generally be distinguished from older sediments of the Nogales Formation by a combination of weaker consolidation, more diffuse and poorly differentiated interbedded sequences of sand and gravel, pinkish gray color, low stratal dips, lack of internal faulting or fracturing, and commonplace development of a subvertical erosional fluting pattern that crosscuts bedding in outcrops (figs. 22 and 23).

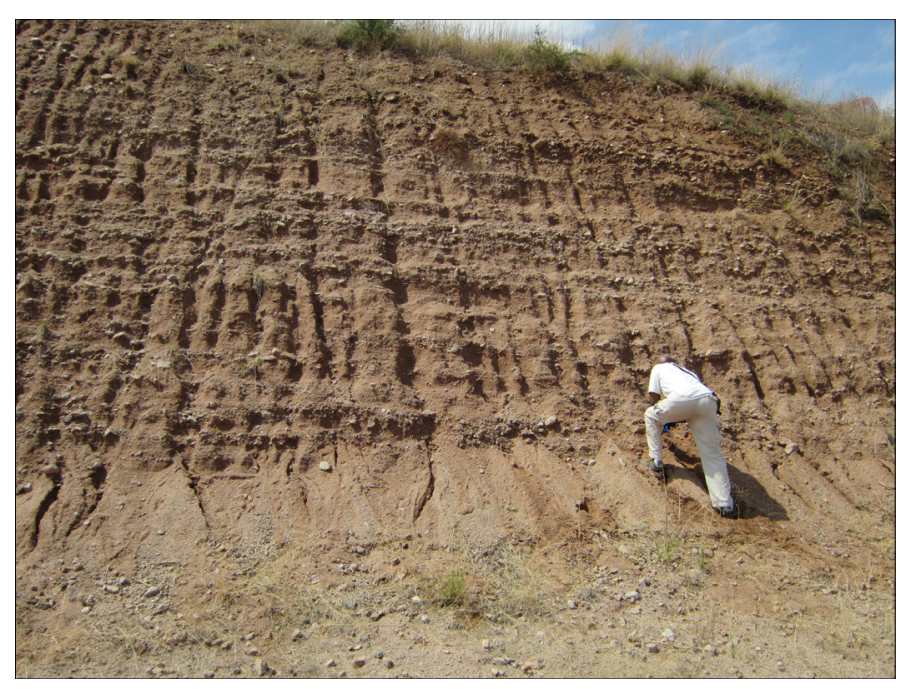

Figure 22. View to west of basal part of basin-fill deposits (QTa) in Potrero Canyon area. Unit is light reddish-brown, pinkish-gray, to light gray, weakly consolidated, moderately to poorly bedded, sandy gravel to gravelly sand. In comparison with Nogales Formation, unit has shallow dips, and has prominent verticalfluting due to erosion across bedding.
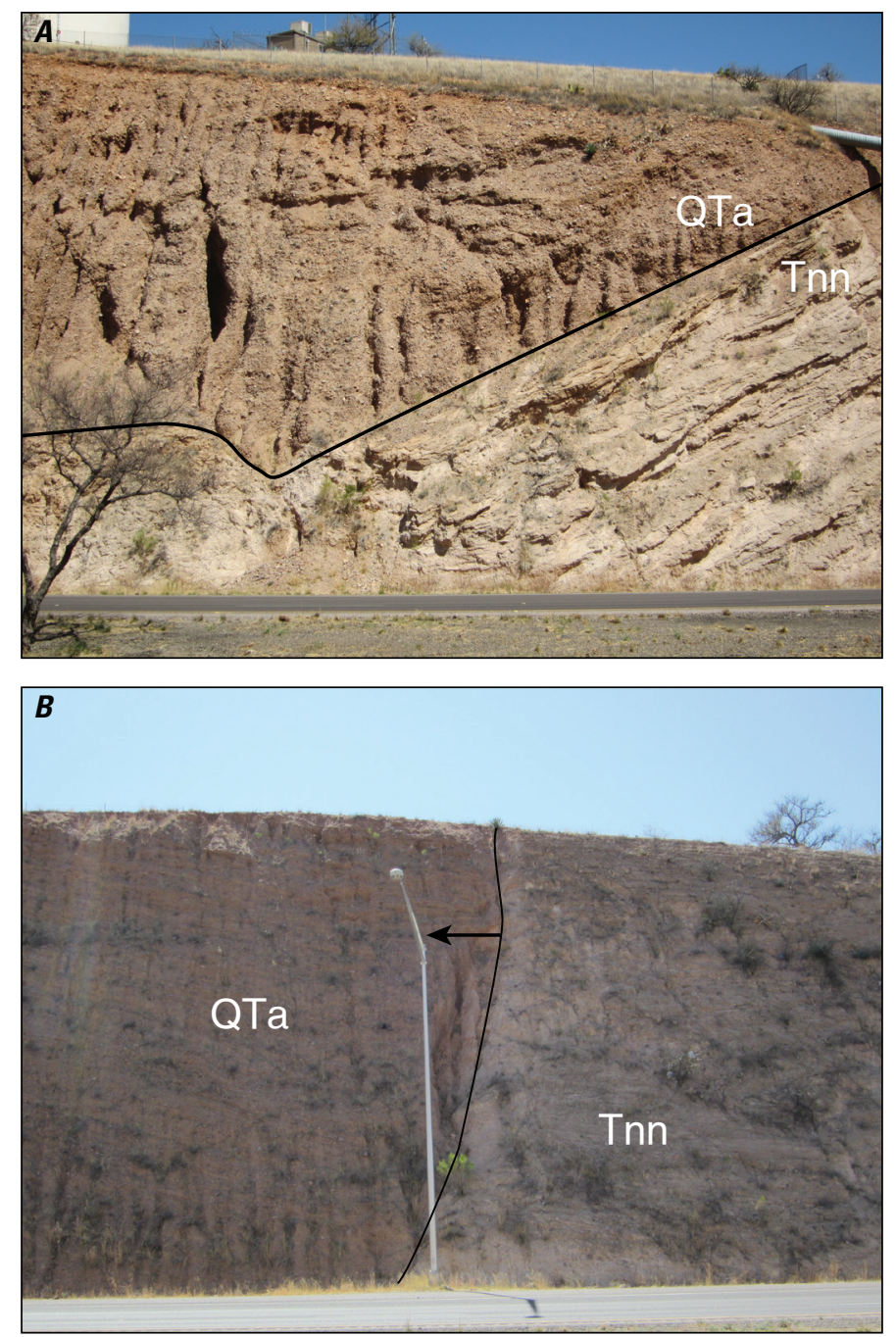

Figure 23. A, View to east of reddish brown basal basin-fill deposits (QTa) in trough cut into underlying Nogales Wash member of the Nogales Formation (Tnn) in a road cut at Crawford Hill; height of outcrop about $20 \mathrm{~m}$. $B$, West view directly across Interstate 19 from road cut at Crawford Hill, showing subvertical fault (black line with arrow on downthrown side) juxtaposing Nogales Wash member (Tnn) in hanging wall, against basin-fill deposits (QTa) in footwall; height of outcrop about $18 \mathrm{~m}$.

The age of basin-fill deposits in the map area is poorly constrained due to the lack of geochronologic age control for the unit. A maximum age constraint is provided by the 11.67 Ma age for basalt flows within the underlying Mariposa member of the Nogales Formation. A minimum age constraint cannot be derived in the map area, but basin-fill deposits that underlie a prominent high, very old, capping gravel deposit immediately north of this map area (Youberg and Helmick, 2001) may correlate with a similar high capping gravel fan deposit in upper Sonoita Creek, east of the map area. Menges (1981) and Menges and McFadden (1981) constrained the age of the latter deposit to early Pleistocene. These relations provide a general late Miocene to early Pleistocene age for the 
basin-fill deposits, with much of the deposition most likely during late Miocene to Pliocene time. This age assignment is consistent with the estimated age ranges of the majority of basin-fill deposits observed in southeastern Arizona (Menges and Pearthree, 1989).

Basin-fill deposits in the region represent the uppermost sections of alluvial-fan deposits that filled the stratigraphically highest portions of the youngest basins, which correspond to the present day system of basins and ranges in the map area. These deposits typically form a relatively thin sedimentary veneer (thicknesses estimated at 50 to $150 \mathrm{~m}$ ) that unconformably overlies older rocks in the depositional basins. There is little to no geophysical or borehole data to constrain subsurface accumulations of buried depositional subbasins that exist along and west of the Santa Cruz River in the continuation of the primary basin to the north (Gettings and Houser, 1997). These relations suggest that the youngest basin-forming episode commonly associated with regional basin-range deformation from 13 to $10 \mathrm{Ma}$ (Menges and Pearthree, 1989), did not form to any significant extent in the map area. Instead, basin fill in this area primarily comprises the final thin and variably distributed depositional-fill sequence in the upper parts of a series of exhumed older middle to early Miocene basins filled primarily with members of the Nogales Formation. Apparently, this early basin-forming interval, recorded by members of the Nogales Formation, did not extend significantly into the late Miocene deformational episode that is regionally associated with basin-fill deposits.

\section{Quaternary Alluvium}

Quaternary deposits in the map area comprise a relatively thin series of alluvial deposits associated with both piedmont alluvial fans and axial streams and their major tributaries that initially developed during the early Pleistocene, and have continued to form into modern time. The primary drainage is the southern reach of the Santa Cruz River, which forms an axial drainage that traverses two physiographic and depositional basins, and an intervening bedrock narrows. This axial drainage is joined by two major tributary drainages, Sonoita Creek and Nogales Wash (figs. 1 and 2), which themselves drain significant areas outside of the two local basins, and numerous smaller intrabasin tributaries of varying sizes that are spatially restricted to a given basin side-slope and, for the larger tributaries, the adjoining bedrock highlands.

Each of the drainages in this system contains a discrete meandering channel belt made up of multiple, braided to anastomosing subchannels and bars, and flanked by undissected floodplains and low terraces. Some smaller tributaries locally contain small alluvial fans between the dominant channelized reaches. The central lowlands are flanked by dissected valley side-slopes that are underlain by mostly pre-Quaternary basin-fill deposits, and (or) older sedimentary and bedrock units. One or more variously eroded and dissected topographic benches covered by thin deposits of terrace or fan gravels are commonly inset into the valley side-slopes, and record successively older and higher former levels, ranging in age from middle Pleistocene to Holocene. These terrace and fan gravels were deposited during local depositional episodes that periodically interrupted longterm stream downcutting. The interfluve areas between incised tributary valleys within the basin piedmonts are characterized by narrowly rounded ridgecrests, developed on the mostly preQuaternary substrate, but locally are capped by flat to gently rounded alluvial-fan surfaces and associated thin fan deposits of middle to early Pleistocene age.

Quaternary alluvium in the map area typically consists of unconsolidated, poorly to moderately bedded, poorly sorted sandy gravel to gravelly sand. The clasts consist of rounded to subangular pebbles, cobbles, and local small boulders, have rock types that generally reflect adjacent bedrock highlands on local tributaries, and more heterogeneous subregional source terrains on the major axial drainages.

The Quaternary deposits in the map area are associated with and controlled by the upper Santa Cruz River system, which flows northwest out of the map area, and ultimately is integrated with the Gila River and lower Colorado River regional drainages. The final phases of closed-basin aggradation, recorded by the highest stratigraphic and topographic levels of basin-fill deposits (QTa), probably ended sometime prior to the deposition of the oldest (highest) alluvial fan deposits of probable early Quaternary age (Qo) that locally cap the basin-fill deposits. This inference is based on regional correlations with similar deposits in surrounding areas (Menges and McFadden, 1981; Menges and Pearthree, 1989). Whether these early Pleistocene fan deposits were graded to an externally drained ancestral Santa Cruz River system cannot be determined from geologic relations in the map area. Regardless, the suite of progressively younger (lower) inset terrace and fan deposits indicates a mostly continually downcutting stream system, which, in turn, indicates that the Santa Cruz River system was externally draining at the time of their formation. Each major map unit at a given height range typically displays diagnostic, age-related geomorphic-surface and pedogenic characteristics that can be correlated with deposits and surfaces with similar characteristics throughout the region. This similarity in diagnostic, age-related characteristics suggests regional-scale, climatecontrolled deposition that periodically interrupted the long term, system-wide pattern of drainage incision. The ultimate source and control for this persistent downcutting in the map area does not appear to be related to any specific local Quaternary tectonic events, given the general absence of deformation in Quaternary deposits, other than a few short isolated Quaternary faults and associated scarps in the eastern Santa Cruz River basin to the north of the map area (Helmick, 1986; Pearthree and Calvo, 1987; Youberg and Helmick, 2001). Long-term dissection is most likely related to local base levels controlled by progressive integration of formerly isolated local basin drainages that evolved into the present-day externally linked, regional Santa Cruz-Gila River drainage system (Menges and Pearthree, 1989). 


\section{Structure}

Structural features in the map area primarily formed during early to late Miocene extensional deformation, which included a phase of early Miocene basin extension from 20 to $13 \mathrm{Ma}$, and main episodes of basin-range extension that occurred in southern Arizona mostly from 13 to $10 \mathrm{Ma}$ (Menges, 1981; Menges and McFadden, 1981; Menges and Pearthree, 1989). Extensional deformation was broadly contemporaneous with deposition of the Nogales Formation, based on observations that all members of the formation are moderately to highly faulted, with abundant intra-formational faults and fractures, and moderate to steeply inclined bedding dips. The Nogales Wash member is pervasively fractured compared to moderate fracturing in the other two members, because the member is more consolidated and contains more brittle, volcaniclastic sandstone units and less claystone than the other two members. Extensional faulting lasted until late Miocene time in the area based on faults which cut only the very oldest post-Nogales Formation late Miocene basin-fill deposits, and Pliocene through Holocene deposits are undeformed.

The main structural feature in the map area is the Mount Benedict horst block (fig. 1), a zone of uplifted Quartz Monzonite of Mount Benedict (Jurassic) and overlying members of the Nogales Formation. The major fault bounding the east side of the horst block is the Mount Benedict fault, and the west side is bound by several north- to northwest-striking faults that progressively downdrop Jurassic monzonite and Miocene Nogales Formation rocks westward into the subsurface. These faults include the Grand Avenue fault, and several concealed faults to the west (sheet 1) which were mapped based on geophysical data.

The main fault in the map area is the northwest-striking Mount Benedict fault (sheets 1 and $2 A-A^{\prime}, B-B^{\prime}$, and $C-C^{\prime}$; fig. 24), originally named and described by Gettings and Houser (1997). The fault forms the northeast side of the Mount Benedict horst block, and is mostly concealed by surficial deposits along the Santa Cruz River (sheet 1); the fault generally controls the course of the river from the Rio Rico area, southward across the international border and into Sonora, Mexico. The only known exposures of the fault in the map area are northeast of the Santa Cruz River, northwest of Guevavi Canyon, and southeast of Sonoita Creek (sheet 1), where the fault plane strikes about $\mathrm{N} 40^{\circ} \mathrm{W}$ and dips about $65^{\circ}$ northeast. In this area, the fault downdrops rocks of the Mariposa member of the Nogales Formation against the Quartz Monzonite of Mount Benedict and also some Salero Formation, which unconformably overlies the monzonite locally. Dark-gray dogtooth calcite fills fractures in the fault plane in places, indicating seepage, or discharge from a carbonate source at depth. A concealed strand of the fault is located east of the exposed fault (sheets 1 and $2 B-B^{\prime}$ ), along the course of the Santa Cruz River. Northward in the Rio Rico area, the fault is concealed and forms the western margin of the Rio Rico basin (fig. 1), and it projects northwestward into the adjacent Peña Blanca Lake and Tubac quadrangles (fig. 2). Our reconnaissance mapping indicates the fault is also exposed in the adjacent Cumero Canyon quadrangle, southeast of the intersection of State Highway 82 and the Santa Cruz River (fig. 2). In this area, the fault juxtaposes red arkosic conglomerate of the Proto Canyon member in the footwall against pinkish- to yellowish-gray volcaniclastic sandstone of the Mariposa member in the hanging wall. Like many other extensional faults in the Basin and Range Province, the northwest-striking Mount Benedict fault is likely a reactivated older structure that had a long complex history; northweststriking faults formed in the region during the Mesoproterozoic, Late Triassic, and during late Miocene basin and range extension (Drewes, 1980).

The Gold Hill fault (sheets 1 and $2 C-C^{\prime}$ and $D-D^{\prime}$ ) was originally mapped by Simons (1974). It strikes north, and dips $65^{\circ}$ west, and terminates against the Mount Benedict fault at its northern end. Along its northern segment, the fault cuts the Quartz Monzonite of Mount Benedict, but southward, the fault downdrops rocks of the Proto Canyon member of the Nogales Formation against Jurassic monzonite. At its southernmost end, the Gold Hill fault loses throw where it offsets units of the Proto Canyon member, and then it becomes concealed and likely terminates beneath an east-west-trending wash, east of Mariposa Road and Grand Avenue (sheet 1).

The Grand Avenue fault (named here) is a newly mapped fault (sheet 1; fig. 25) concealed along much of its trace. At its southern end, the fault strikes northeast and is

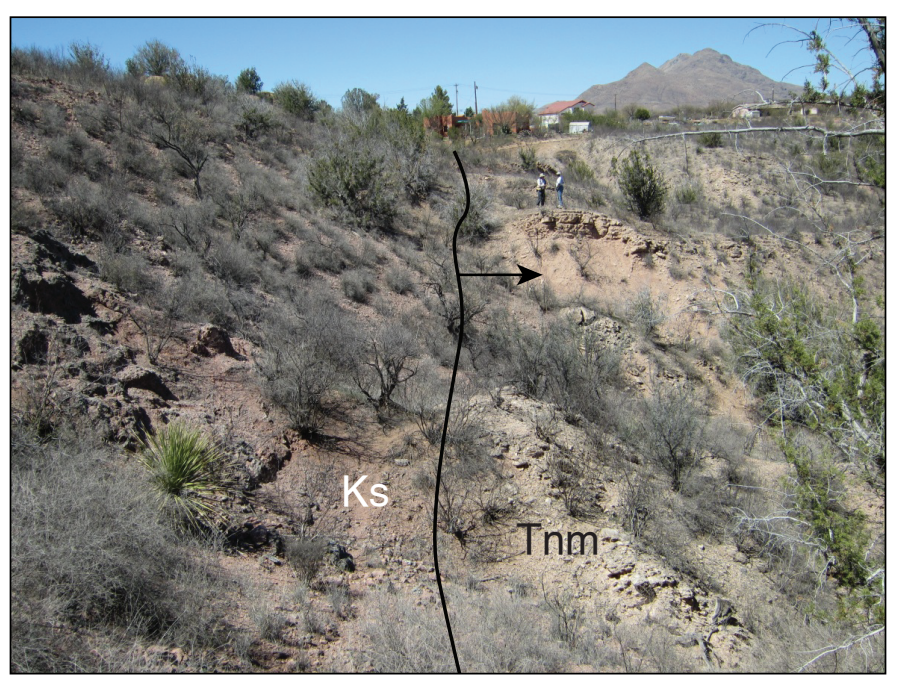

Figure 24. Northwest view along Mount Benedict fault (black line with arrow on downthrown side) east of Santa Cruz River; gray and dark brown beds (on left) of the Salero Formation (Ks) in the footwall, and yellowish to pinkish gray beds (on right, on which geologists are standing) are the Mariposa member of Nogales Formation (Tnm) in the hanging wall; fault plane strikes N. $40^{\circ} \mathrm{W}$. and dips $65^{\circ}$ northeast. Peaks in the San Cayetano Mountains are on skyline. 


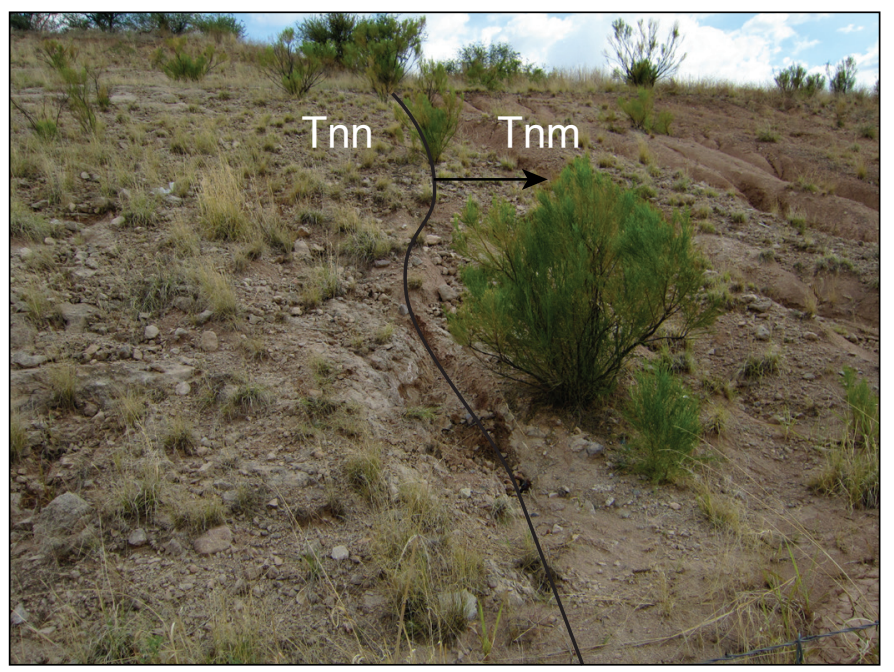

Figure 25. Southwest view of Grand Avenue fault (black line with arrow on downthrown side) just south of Mariposa Road and west of Grand Avenue; gray sandstone of the Nogales Wash member (Tnn) on left in footwall, and pink claystone in Mariposa member (Tnm) on right in hanging wall; height of large shrub in center of photograph is about $1 \mathrm{~m}$.

concealed in Ephraim Canyon (sheets 1 and $2 F-F^{\prime}$ ); north of the canyon, the fault is concealed, but it separates isolated outcrops of the Mariposa member on the downthrown side from rocks of the Nogales Wash member on the upthrown side (sheet 1 ). The only presently known exposures of the fault are just south of Mariposa Road and west of Grand Avenue (sheet 1 and fig. 25), where it strikes about N. $30^{\circ}$ E. and dips $60^{\circ}$ northwest, and juxtaposes massive claystone of the Mariposa member in the hanging wall against volcaniclastic sandstone of the Nogales Wash member in the footwall (sheet 2, $E-E^{\prime}$ ). Slickenlines on the fault plane trend N. $70^{\circ} \mathrm{W}$. and plunge $56^{\circ} \mathrm{NW}$, indicating latest movement on the fault was mostly dip-slip. North of Mariposa Road, the fault bends northwestward (sheet 1), and juxtaposes volcaniclastic sandstone and conglomerate of the Mariposa member in the hanging wall, against volcaniclastic sandstone of the Proto Canyon member in the footwall (sheet 2, $D-D^{\prime}$ ). Farther north, the Grand Avenue fault is concealed (sheet 1), and hanging wall rocks of the Mariposa and Proto Canyon members in the subsurface are interpreted (based on geophysical modeling) to be progressively downdropped northward against the Quartz Monzonite of Mount Benedict in the footwall (sheet 2, $B-B^{\prime}$ and $C-C^{\prime}$ ), indicating significant westside down offset. At its northern end, the Grand Avenue fault terminates at the Mount Benedict fault (sheet 1), similar to the Gold Hill fault. Several other faults are mapped west of the Grand Avenue fault, and these faults are concealed and were interpreted based on airborne transient electromagnetic (TEM) data and other geophysical data. The Grand Avenue fault and faults to the west together form a complex graben system in the subsurface of the western part of the map area (sheets 1 and $2, C-C^{\prime}$ ).

The Proto Canyon fault (sheets 1 and 2, $D-D^{\prime}, E-E^{\prime}$, and $F-F^{\prime}$ ) parallels Proto Canyon along State Highway 82, where it strikes about $\mathrm{N} .45^{\circ} \mathrm{E}$. and dips southeast, and offsets rocks in the lower part of the Proto Canyon member. In the Proto Canyon area, the fault downdrops cliff-forming, cyclic units in the lower part of the member (fig. 10) in the hanging wall, against arkose conglomerate and sandstone (fig. 9) in the basal parts of the Proto Canyon member in the footwall. From Proto Canyon northeastward, the fault eventually cuts out the arkose units, and downdrops the cyclic, cliff-forming units against the Quartz Monzonite of Mount Benedict near the eastern edge of the map area (sheet 1). The southern segment of the Proto Canyon fault offsets rocks mostly of the Nogales Wash and Mariposa members (sheet 1), and it extends southward into Mexico. The Yerba Buena Canyon fault (sheet 1) is subparallel to the Proto Canyon fault, and is also down to the southeast. Like the Proto Canyon fault, it offsets units mostly of the Proto Canyon member along its northern segment, and offsets the Mariposa and Nogales Wash members along its southern segment, where it extends southward into Mexico.

In the northwestern part of the map area, faults bound the west and east flanks of the San Cayetano Mountains to form a horst block (sheets 1 and 2, $A-A^{\prime}$ ). The Rio Rico fault (named here) is the range-front fault on the west flank of the San Cayetano Mountains, and is down-to-the-west where it forms the eastern margin of the Rio Rico basin (fig. 1). The fault is exposed at several locations; at the southernmost location, the fault juxtaposes post-Nogales Formation basin fill (unit QTa) in the hanging wall against rocks of the Salero Formation in the footwall, and strikes about N. $35^{\circ} \mathrm{W}$. and dips $70^{\circ}$ southwest (sheet 1). Northward along the Rio Rico fault, Tertiary rhyolitic intrusive rocks in the hanging wall are juxtaposed against mostly sedimentary rocks of the Salero Formation in the footwall; these latter rocks compose most of the high ridge of the San Cayetano Mountains.

The San Cayetano fault of Drewes (1972) bounds the east flank of the San Cayetano Mountains, is down-to-the-east, and offsets rocks mostly of the Proto Canyon member of the Nogales Formation and Grosvenor Hills Volcanics in the hanging wall against the Salero Formation in the footwall (sheet 1). North of the map area, the fault offsets Grosvenor Hills Volcanics in the hanging wall against the Salero Formation in the footwall, where Drewes estimated about 300 to $760 \mathrm{~m}$ of vertical displacement along the fault. Drewes (1972) reported this displacement was likely cumulative over a period of time following late Oligocene volcanism and continuing after deposition of the Miocene Nogales Formation. South of the San Cayetano Mountains and Sonoita Creek (sheet 1), the San Cayetano fault offsets rocks mostly of the Mariposa member of the Nogales Formation (sheet 1, and fig. 26), and then it terminates against the Mount Benedict fault. 


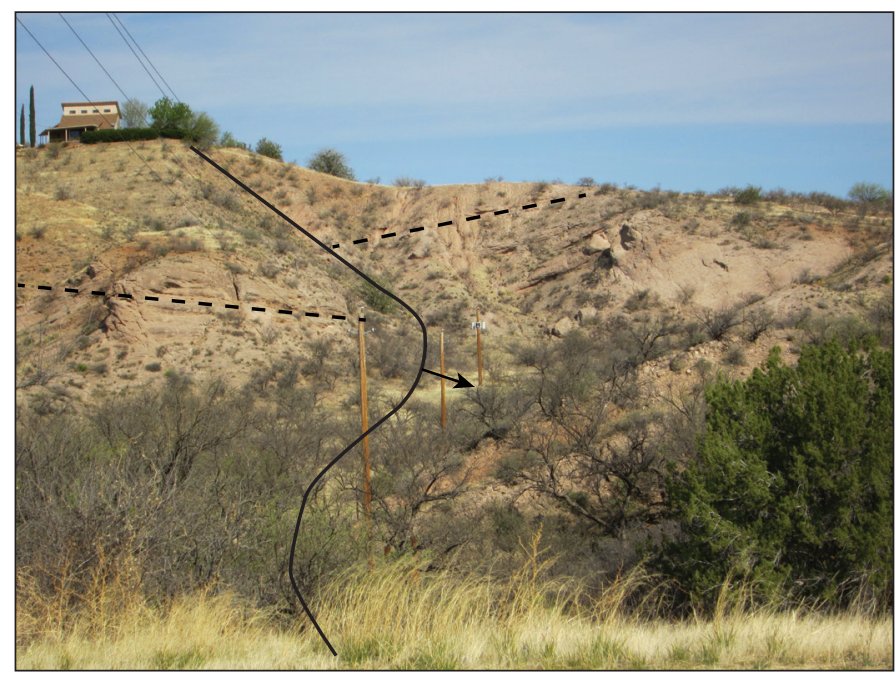

Figure 26. North view along southern end of the east-dipping San Cayetano fault just south of Sonoita Creek. Main fault (thick black line with arrow on downthrown side) offsets rocks of the Mariposa member of the Nogales Formation, which dip about $15^{\circ}$ west in the hanging wall (right of fault), and are gently eastdipping in the footwall (left of fault); bedding dips indicated by thin black dashed lines on both sides of fault.

\section{Summary}

The objectives of mapping the Rio Rico and Nogales 1:24,000-scale quadrangles were to define the geologic framework to support ongoing multidisciplinary USGS projects in the Nogales area, including the Tucson Water Science Center Transboundary Aquifer Act Project, U.S.-Mexico Border Environmental Health Initiative, and the assessment of concealed porphyry copper deposits in the area. This work will also provide important information for other agencies investigating flood hazards and water storage in the Nogales Wash and Santa Cruz River areas, and for studies detecting and predicting the location of illegal smuggling tunnels beneath the international border.

The oldest rocks in the quadrangle include the Quartz Monzonite of Mount Benedict of Late to Middle Jurassic age. These rocks are highly deformed and are intruded by numerous mostly northwest-trending diorite and diabase dikes, and they form a confining unit below the Miocene Nogales Formation and Tertiary through Quaternary deposits in the map area.

The Upper Cretaceous Salero Formation (about 72 to $69 \mathrm{Ma}$ ) unconformably overlies the Quartz Monzonite of Mount Benedict along the Santa Cruz River, southeast of Rio Rico. Most of the unit in that area consists of thick-bedded, wellconsolidated conglomerate and sandstone, with clasts of silicic volcanic rocks and some granite. The Salero Formation forms the high ridge of the San Cayetano Mountains on the north edge of the map area, where it consists chiefly of conglomerate, sandstone, argillite and quartzite, intruded by abundant west- to northwest-trending latite dikes and plugs of Tertiary age.
The Grosvenor Hills Volcanics (Drewes, 1968) are exposed north of Sonoita Creek and east of the San Cayetano Mountains, and consist mostly of rhyolite and rhyodacitic tuff, vitric lithic tuff, agglomerate, flow breccia, and latite tuff. We follow Drewes (1972) and subdivide the Grosvenor Hills Volcanics into middle rhyolite and upper rhyodacite members; the basal silt and gravel member is not exposed in the map area. Our new argon geochronology reveals some units in the upper rhyodacite member are significantly younger than previously interpreted (28-27 Ma) and are from about 27 to $23 \mathrm{Ma}$.

Our new mapping and supporting geochronologic, geophysical, and hydrogeologic studies resulted in significant stratigraphic revision of the Nogales Formation, and we defined three new informal members, including (from base to top) the Proto Canyon, Nogales Wash, and Mariposa members; all three members are separated by unconformities. New ${ }^{40} \mathrm{Ar} /{ }^{39} \mathrm{Ar}$ geochronology indicates the maximum age of the formation is about 20 to $18 \mathrm{Ma}$, and the minimum age is about $11 \mathrm{Ma}$; the minimum age is based on whole-rock dates from basalt flows in the Mariposa member near the international border (11.67 Ma; Cosca and others, 2013). ${ }^{40} \mathrm{Ar} /{ }^{39} \mathrm{Ar}$ geochronology analyses of detrital grains from the Nogales Formation range in age from 28 to $23 \mathrm{Ma}$, and correspond to the provenance of detrital material from the Grosvenor Hills Volcanics. The Proto Canyon member consists of basal debrisflow conglomerate and arkose sandstone and conglomerate; a lower cliff-forming part consisting mostly of fluvial, cyclic, fining-upward sequences; a middle part consisting of alternating beds of volcaniclastic conglomerate, arkosic conglomerate, and sandstone and claystone; and an upper part containing volcaniclastic conglomeratic sandstone and sandstone. The Nogales Wash member is exposed in the southern part of the map area, where it consists of massive, cliff-forming volcaniclastic sandstone and conglomeratic sandstone in the basal part, and ledge-forming, alternating beds of thin- to thickbedded, volcaniclastic sandstone and conglomeratic sandstone in the upper part. Units of the Nogales Wash member are pervasively fractured and faulted, contain abundant pumice fragments, and generally lack claystone units unlike the other two members of the formation. The Mariposa member consists of alternating beds of calcareous, volcaniclastic conglomeratic sandstone, sandstone, siltstone, and claystone. Basalt flows dated at $11.67 \mathrm{Ma}$ are in the lower parts of the member near the international border, and this age constrains the minimum age of the Nogales Formation at about 11 Ma. Massive claystone units of the member in the Mariposa Road area represent playa deposits in an axial basin facies of the member and may be significant confining units.

Major episodes of extensional deformation were contemporaneous with deposition of the Nogales Formation as indicated by the observation that all units of the formation are moderately to highly faulted, with abundant intraformational faults and fractures, and moderate to steeply inclined bedding dips. Extensional faulting lasted until latest Miocene time based on faults which cut only the very oldest post-Nogales Formation, late Miocene basin-fill deposits; Pliocene through 
Holocene basin-fill deposits exposed in the map area are undeformed. The main structural feature in the map area is the Mount Benedict horst block, a zone consisting of uplifted Jurassic Quartz Monzonite of Mount Benedict and overlying units of the Nogales Formation. The major fault in the map area is the Mount Benedict fault bounding the east side of the horst block, and it controls the location of the course of the Santa Cruz River from the Rio Rico area, southward into Mexico. The fault is exposed northwest of Guevavi Canyon and southeast of Sonoita Creek where it dips northeast and offsets rocks of the Jurassic monzonite and overlying Salero Formation in the footwall, against the Mariposa member of the Nogales Formation in the hanging wall.

The Grand Avenue fault is a newly mapped fault that forms the west side of the Mount Benedict horst block. The fault is exposed just south of Mariposa Road and west of Grand Avenue where it strikes northeast and dips northwest, and slickenlines on the fault plane indicate the sense of movement was mostly dip-slip. The southern part of the fault juxtaposes rocks of the Nogales Wash member against those of the Mariposa member of the Nogales Formation, but northward, rocks of the Mariposa member are faulted against those of the Proto Canyon member and the Quartz Monzonite of Mount Benedict. Several other concealed faults are mapped west of the Grand Avenue fault, and these faults were interpreted from airborne transient electromagnetic and other geophysical data. The Grand Avenue fault and concealed faults to the west form a complex graben system in the subsurface in the western part of the map area.

The newly mapped Proto Canyon fault parallels Proto Canyon along State Highway 82, where it strikes northeast, is down to the southeast, and mainly offsets rocks of the Proto Canyon member. Farther south, it offsets the Nogales Wash and Mariposa members and extends southward into Mexico. The Yerba Buena Canyon fault is subparallel to the Proto Canyon fault, and like the Proto Canyon fault, it is down to the southeast and offsets rocks of the Proto Canyon member to the north and the Nogales Wash and Mariposa members to the south where it extends into Mexico.

Major faults in the northern part of the map area bound the west and east flanks of the San Cayetano Mountains to form a horst block. The Rio Rico fault is the range-front fault on the west flank of the mountains; it is down to the west and forms the east margin of the Rio Rico basin. The fault juxtaposes lower basin-fill units (late Miocene) in the hanging wall against rocks of the Salero Formation in the footwall. The San Cayetano fault on the east side of the San Cayetano Mountains downdrops rocks - mostly of the Nogales Formation and Grosvenor Hills Volcanics in the hanging wall - against Salero Formation in the footwall. At its southern end, the San Cayetano fault offsets rocks of the Mariposa member of the Nogales Formation, and then terminates at the Mount Benedict fault.

\section{Acknowledgments}

We greatly appreciate the technical reviews of the report completed by Ralph Shroba and Kenzie Turner; their comments and suggestions vastly improve the report. Jeremy Havens was responsible for digitally drafting all of the report illustrations, and the cross sections on sheets 2. Thanks to Gary Skipp who conducted X-ray diffraction analyses on samples from the Nogales Formation. Ted Brandt digitally compiled, edited, and mosaicked the topographic base map for sheet 1 .

\section{References Cited}

Betancourt, J.L., 1990, Tucson's Santa Cruz River and the arroyo legacy: Tucson, University of Arizona, Ph.D. dissertation, $239 \mathrm{p}$.

Birkeland, P.W., 1999, Soils and Geomorphology: New York, N.Y., Oxford University Press, 430 p.

Bull, W.B, 1991, Geomorphic responses to climate change: New York, N.Y., Oxford University Press, 326 p.

Callegary, J.B., Page, W.R., Megdal, Sharon, Gray, Floyd, Scott, C.A., Berry, M.E., Rangel, Miguel, Ramos, L.O., Menges, C.M., and Jones, Alison, 2011, Hydrogeologic framework of the upper Santa Cruz basin south of Amado, Arizona, using well logs, gravity, magnetics, and frequency and time domain electromagnetics [abs.]: American Geophysical Union Abstracts with Programs, Fall 2011 meeting, San Francisco, Calif., 5-9, December 2011.

Cohen, K.M., Finney, S.C., Gibbard, P.L., and Fan, J.-X., 2014, The ICS International Chronostratigraphic Chart, ver. 2014/10: International Commission on Stratigraphy, accessed February 25, 2015, at http:/www.stratigraphy.org/ ICSchart/ChronostratChart2014-10.pdf [Version 2014/10 in Episodes, v. 36, no. 3, p. 199-204.]

Cooper, J.R., 1973, Geologic map of the Twin Buttes quadrangle, southwest of Tucson, Pima County, Arizona: U.S. Geological Survey Miscellaneous Geologic Investigations Map I-745, scale 1:48,000.

Cosca, M.A., Page, W.R., Gray, Floyd, Menges, C.M., Lee, J.P., and Bultman, M.W., 2013, ${ }^{40} \mathrm{Ar} /{ }^{39} \mathrm{Ar}$ geochronology of the Oligocene-Miocene Grosvenor Hills Volcanics and the Miocene Nogales Formation, upper Santa Cruz basin, southern Arizona [abs.]: Geological Society of America Abstracts with Programs, v. 45, no. 7, p. 129.

Drewes, Harald, 1968, New and revised stratigraphic names in the Santa Rita Mountains of southeastern Arizona, contributions to stratigraphy: U.S. Geological Survey Bulletin, 1274-C, p. C1-C15 
Drewes, Harald, 1971, Geologic map of the Mount Wrightson quadrangle, southeast of Tucson, Arizona: U.S. Geological Survey Miscellaneous Investigations Map I-614, scale $1: 48,000$.

Drewes, Harald, 1972, Cenozoic rocks of the Santa Rita Mountains, southeast of Tucson, Arizona: U.S. Geological Survey Professional Paper 746, 66 p.

Drewes, Harald, 1980, Tectonic map of southeast Arizona: U.S. Geological Survey Miscellaneous Investigations Map I-1109, scale 1:125,000.

Gettings, M.E., and Houser, B.B., 1997, Basin Geology of the upper Santa Cruz valley, Pima and Santa Cruz Counties, southeastern Arizona: U.S. Geological Survey Open-File Report 97-676, 39 p.

Gettings, M.E., 2002, An interpretation of the 1996 aeromagnetic data for the Santa Cruz basin, Tumacacori Mountains, south central Arizona: U.S. Geological Survey Open-File Report 02-99, $44 \mathrm{p}$.

Gray, Floyd, Page, W.R., Bultman, M., and Menges, C., 2014, Hydrogeologic characteristics of the Miocene Nogales Formation-Potential new deeper sources of groundwater in the upper Santa Cruz basin, southern Arizona [abs.]: Geological Society of America Abstracts with Programs, v. 46, No. 6, p. 118.

Hayes. P.T., 1970, Cretaceous paleogeography of southeastern Arizona and adjacent areas: U.S. Geological Survey Professional Paper, 658-B, p. B1-B42.

Helmick, W.R., 1986, The Santa Cruz River terraces near Tubac, Santa Cruz County, Arizona: University of Arizona M.S., thesis, Tucson, 96 p.

Houser, B.B., Peters, L., Esser, R.P., and Gettings, M.E., 2004, Stratigraphy and tectonic history of the Tucson basin, Pima County, Arizona, based on the Exxon State (32)-1 well: U.S. Geological Survey Scientific Investigations Report 2004-5076, 34 p.

Lindsey, D.A., and Van Gosen, B.S., 2005, Surficial geologic map of the Mount Hopkins and northern part of the San Cayetano 7.5-minute quadrangles, Santa Cruz and Pima Counties, Arizona: Arizona Geological Survey Contributed Map 06-A (CM-06-A), 1 sheet, scale 1:24,000.

Lindsey, D.A., and Van Gosen, B.S., 2010, Processes of terrace formation on the piedmont of the Santa Cruz River valley during Quaternary time, Green Valley-Tubac area, southeastern Arizona: U.S. Geological Survey Scientific Investigations Report 2010-5028, 39 p.

Marvin, R.F., Stern, T.W., Creasey, S.C., and Mehnert, H.H., 1973, Radiometric ages of igneous rocks from Pima, Santa Cruz, and Cochise Counties, Arizona: U.S. Geological Survey Bulletin 1379, $27 \mathrm{p}$.

Menges, C.M., 1981, The Sonoita Creek basin, implications for late Cenozoic tectonic evolution of basin and ranges in southeastern Arizona: Tucson, University of Arizona, M.S. thesis, $239 \mathrm{p}$.
Menges, C.M., and McFadden, L.D., 1981, Evidence for a latest Miocene to Pliocene transition from Basin-and-Range tectonic to post tectonic landscape evolution in southeastern Arizona, in Stone, Claudia, and Jenny, J.P., eds., Arizona Geological Society Digest XIII, p. 151-160.

Menges, C.M., and Pearthree, P.A., 1989, Late Cenozoic tectonism in Arizona and its impact on regional landscape evolution, in Jenny, J.P., and Reynolds, S.J., eds., Arizona Geological Society Digest XVII, p. 649-680.

Nelson, F.J., 1963, The Geology of the Peña Blanca and Walker Canyon areas, Santa Cruz County, Arizona: Tucson, University of Arizona M.S. Thesis, 82 p.

Page, W.R., Gray, F., Menges, C., Berry, M.E., Cosca, M., and Callegary, J., 2011, Re-evaluating the stratigraphy, structure, and hydrogeology of the Miocene Nogales Formation, upper Santa Cruz basin, southern Arizona and northern Sonora [abs.]: Geological Society of America Abstracts with Programs, v. 43, no. 5, p. 79.

Pearthree, P.A., and Biggs, T.H., 1999, Surficial geology and geologic hazards of the Tucson Mountains: Arizona Geological Survey Open-File Report 99-22, 12 p., 2 sheets, scale 1:24,000.

Pearthree, P.A., and Calvo, S.S., 1987, The Santa Rita fault zone-Evidence for large magnitude earthquakes with very long recurrence intervals, Basin and Range Province of southeastern Arizona: Bulletin of the Seismological Society of America, v. 77, p. 97-116.

Pearthree, P.A., and Youberg, A., 2000, Surficial geology and geologic hazards of the Green Valley-Sahuarita Area, Pima County, Arizona: Arizona Geological Survey Open-File Report 99-22. 12 p., 2 sheets, scale 1:24,000.

Peterson, J.A., Berquist, J.R., Reynolds, S.J., Page-Nedell, S.S., 1990, Geologic map of the Tucson and Nogales quadrangles (Az., 1:125,000-scale); a digital database: U.S. Geological Survey Open-File Report 01-275, scale 1:125,000.

Simons, F.S., 1974, Geologic map and sections of the Nogales and Lochiel quadrangles, Santa Cruz County, Arizona: U.S.Geological Survey Scientific Investigations Map I-762, 9 p. pamphlet, scale 1:48,000.

U.S. Department of Agriculture Natural Resources Conservation Service, 2008, Soil Survey Geographic (SSURGO) database for Santa Cruz and parts of Cochise and Pima Counties, Arizona: U.S. Department of Agriculture Natural Resources Conservation Service, az667, accessed 10/21/2010, at http://websoilsurvey.nrcs.usda.gov/.

Wood, M.L., House, P.K., and Pearthree, P.A., 1999, Historical geomorphology and hydrology of the Santa Cruz River, Arizona Geological Survey Open-File Report 99-13, 98 p., 1 sheet, scale 1:100,000.

Youberg, Ann, and Helmick, W.R., 2001, Surficial geologic maps and geologic hazards of the Amado-Tubac area, Santa Cruz and southern Pima Counties, Arizona: Arizona Geological Survey Digital Map 13, scale 1:24,000. 
Appendix Table 1-1. Combined ${ }^{40} \mathrm{Ar} /{ }^{39} \mathrm{Ar}$ data for Grosvenor Hills Volcanics and Nogales Formation. (Click here to access digital file.)

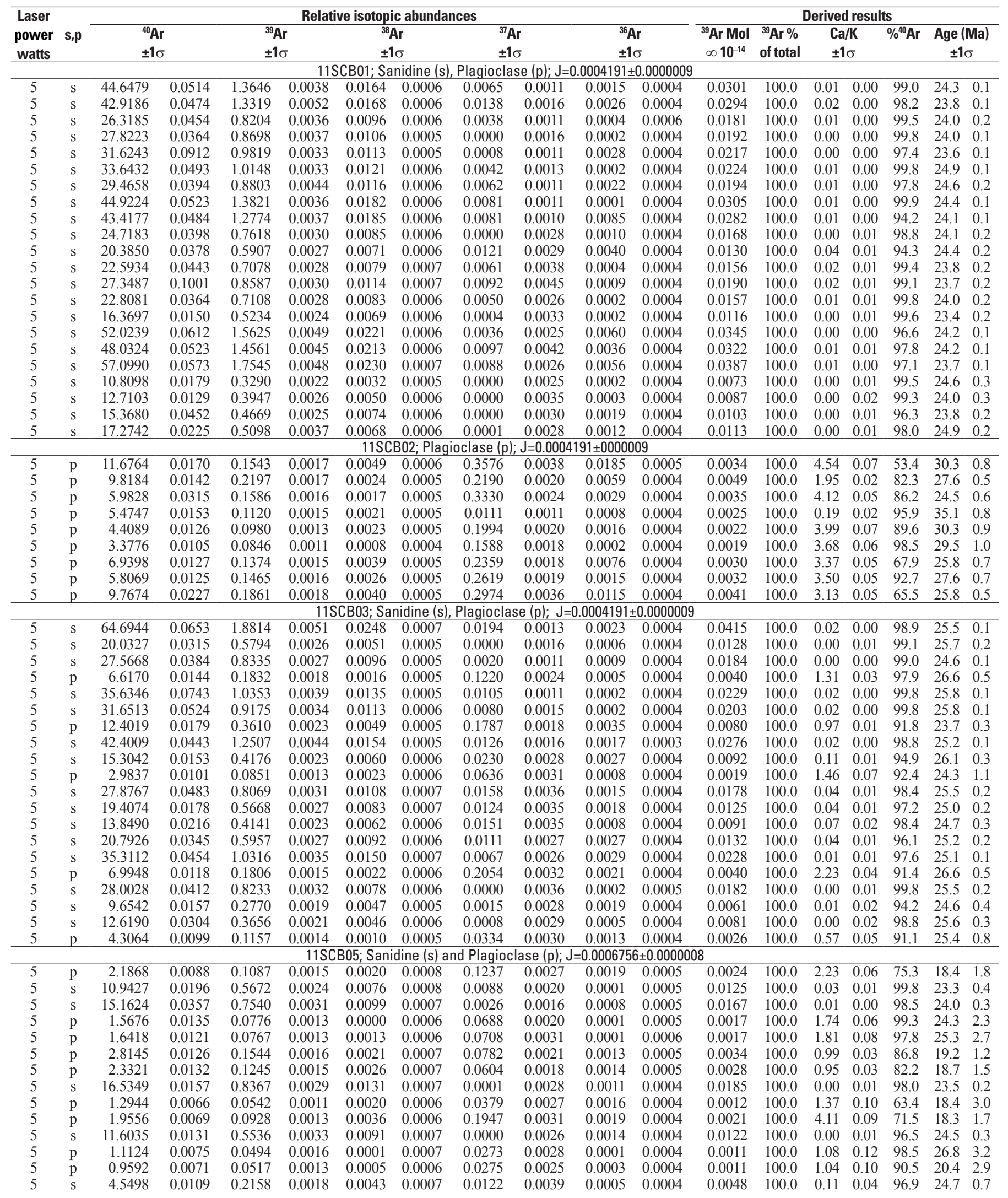


Appendix Table 1-1. Combined ${ }^{40} \mathrm{Ar} /{ }^{39} \mathrm{Ar}$ data for Grosvenor Hills Volcanics and Nogales Formation. (Click here to access digital file.) -Continued

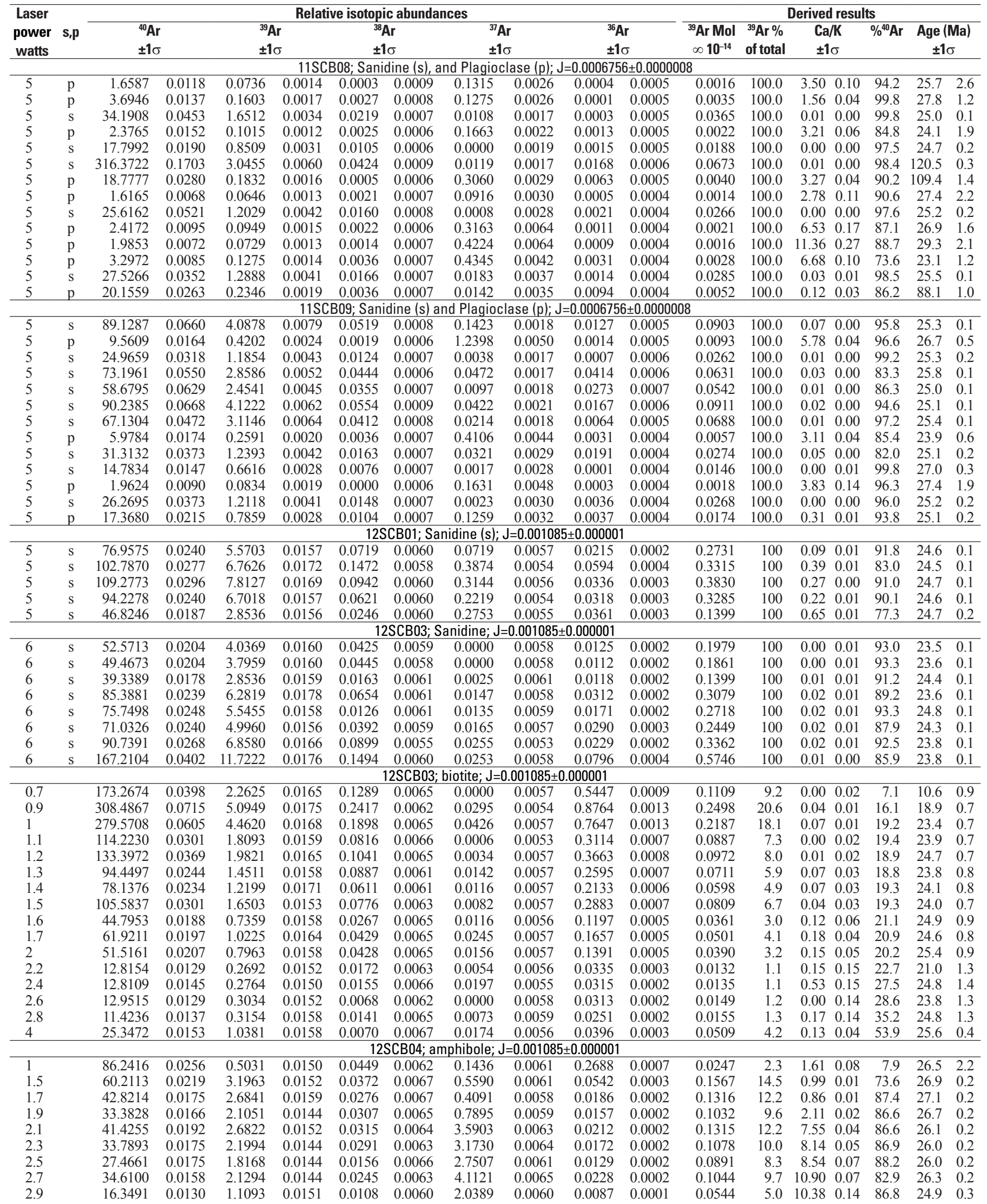


Appendix Table 1-1. Combined ${ }^{40} \mathrm{Ar} /{ }^{39} \mathrm{Ar}$ data for Grosvenor Hills Volcanics and Nogales Formation. (Click here to access digital file.) -Continued

\begin{tabular}{|c|c|c|c|c|c|c|c|c|c|c|c|c|c|c|c|c|c|}
\hline \multirow{2}{*}{$\begin{array}{l}\text { Laser } \\
\text { power } \\
\text { watts }\end{array}$} & \multicolumn{10}{|c|}{ Relative isotopic abundances } & \multicolumn{7}{|c|}{ Derived results } \\
\hline & $\begin{array}{l}{ }^{40} \mathrm{~A} \\
\pm 10\end{array}$ & & $\begin{array}{l}{ }^{39} \mathrm{~A} \\
\pm 1 \mathrm{C}\end{array}$ & & & & \pm 1 & & $\begin{array}{l}{ }^{36} \mathrm{~A} \\
\pm 1\end{array}$ & & $\begin{array}{c}{ }^{39} \mathrm{Ar} \mathrm{Mol} \\
\infty 10^{-14}\end{array}$ & $\begin{array}{l}{ }^{39} \mathrm{Ar} \% \\
\text { of total }\end{array}$ & & $\begin{array}{l}\mathbf{1} \mathbf{K} \\
\mathrm{l} \sigma\end{array}$ & $\%{ }^{40} \mathrm{Ar}$ & $\begin{array}{r}\text { Age ( } \\
\pm 1\end{array}$ & \\
\hline & & & & & 2SCBO & iphib & $; \mathrm{J}=0.0$ & $35 \pm 0.000$ & $01-\mathrm{C}_{0}$ & tinued & & & & & & & \\
\hline 3.2 & 7.8060 & 0.0127 & 0.5065 & 0.0150 & 0.0000 & 0.0064 & 0.8796 & 0.0061 & 0.0046 & 0.0001 & 0.0248 & 2.3 & 9.81 & 0.28 & 85.0 & 25.5 & 0.7 \\
\hline 3.5 & 10.0979 & 0.0142 & 0.5996 & 0.0144 & 0.0274 & 0.0062 & 1.2151 & 0.0059 & 0.0071 & 0.0001 & 0.0294 & 2.7 & 11.45 & 0.27 & 81.6 & 26.8 & 0.6 \\
\hline 4 & 15.3325 & 0.0142 & 0.9512 & 0.0144 & 0.0100 & 0.0066 & 2.1173 & 0.0060 & 0.0105 & 0.0002 & 0.0466 & 4.3 & 12.58 & 0.18 & 82.7 & 26.0 & 0.4 \\
\hline 5 & 22.6825 & 0.0142 & 1.5034 & 0.0137 & 0.0287 & 0.0062 & 3.4686 & 0.0060 & 0.0127 & 0.0002 & 0.0737 & 6.8 & 13.04 & 0.12 & 86.6 & 25.5 & 0.2 \\
\hline & & & & & & 2SCB04; & iotite; J= & $.001085 \pm$ & 000001 & & & & & & & & \\
\hline 0.9 & 59.3366 & 0.0209 & 0.6274 & 0.0151 & 0.0123 & 0.0062 & 0.0014 & 0.0059 & 0.1819 & 0.0006 & 0.0308 & 0.5 & 0.02 & 0.07 & 9.4 & 17.3 & 1.2 \\
\hline 1 & 35.4551 & 0.0165 & 0.7092 & 0.0151 & 0.0105 & 0.0062 & 0.0126 & 0.0061 & 0.0937 & 0.0004 & 0.0348 & 0.6 & 0.13 & 0.06 & 21.9 & 21.3 & 0.7 \\
\hline 1.1 & 54.7002 & 0.0200 & 2.2340 & 0.0152 & 0.0407 & 0.0062 & 0.0079 & 0.0055 & 0.0919 & 0.0004 & 0.1095 & 1.8 & 0.03 & 0.02 & 50.4 & 24.0 & 0.3 \\
\hline 1.2 & 42.9335 & 0.0183 & 2.2300 & 0.0158 & 0.0322 & 0.0061 & 0.0270 & 0.0058 & 0.0496 & 0.0003 & 0.1093 & 1.8 & 0.09 & 0.02 & 65.9 & 24.6 & 0.2 \\
\hline 1.3 & 61.8963 & 0.0219 & 3.4004 & 0.0147 & 0.0377 & 0.0065 & 0.0241 & 0.0056 & 0.0564 & 0.0004 & 0.1667 & 2.7 & 0.05 & 0.01 & 73.1 & 25.8 & 0.2 \\
\hline 1.4 & 72.4410 & 0.0228 & 4.2850 & 0.0161 & 0.0551 & 0.0060 & 0.0222 & 0.0057 & 0.0493 & 0.0003 & 0.2101 & 3.4 & 0.04 & 0.01 & 79.9 & 26.2 & 0.1 \\
\hline 1.5 & 86.5317 & 0.0246 & 5.3938 & 0.0156 & 0.0654 & 0.0061 & 0.0157 & 0.0055 & 0.0441 & 0.0003 & 0.2644 & 4.3 & 0.02 & 0.01 & 85.0 & 26.5 & 0.1 \\
\hline 1.6 & 91.8639 & 0.0284 & 5.8085 & 0.0157 & 0.0892 & 0.0061 & 0.0299 & 0.0055 & 0.0435 & 0.0003 & 0.2848 & 4.6 & 0.04 & 0.01 & 86.0 & 26.4 & 0.1 \\
\hline 1.7 & 79.4038 & 0.0246 & 5.0697 & 0.0162 & 0.0621 & 0.0060 & 0.0158 & 0.0057 & 0.0358 & 0.0003 & 0.2485 & 4.0 & 0.02 & 0.01 & 86.7 & 26.4 & 0.1 \\
\hline 2 & 211.4131 & 0.0498 & 13.3078 & 0.0200 & 0.2053 & 0.0058 & 0.0824 & 0.0059 & 0.0960 & 0.0005 & 0.6524 & 10.5 & 0.05 & 0.00 & 86.6 & 26.7 & 0.1 \\
\hline 2.2 & 193.2880 & 0.0459 & 12.4140 & 0.0185 & 0.1687 & 0.0060 & 0.0643 & 0.0057 & 0.0708 & 0.0004 & 0.6086 & 9.8 & 0.04 & 0.00 & 89.2 & 27.0 & 0.1 \\
\hline 2.4 & 185.1089 & 0.0439 & 11.8338 & 0.0188 & 0.1799 & 0.0062 & 0.0566 & 0.0 & 0.0698 & 0.0004 & 0.5801 & 9.4 & 0.04 & 0.00 & 88.9 & 27.0 & 0.1 \\
\hline 2.6 & 207.2727 & 0.0459 & 13.3878 & 0.0189 & 0.1901 & 0.0062 & 0.0820 & 0.0058 & 0.0754 & 0.0004 & 0.6563 & 10.6 & 0.05 & 0.00 & 89.3 & 26.8 & 0.1 \\
\hline 2.8 & 172.4781 & 0.0410 & 11.0814 & 0.0185 & 0.1371 & 0.0060 & 0.0822 & 0.0058 & 0.0619 & 0.0004 & 0.5432 & 8.8 & 0.05 & 0.00 & 89.4 & 27.0 & 0.1 \\
\hline 3 & 160.5932 & 0.0390 & 10.5928 & 0.0178 & 0.1311 & 0.0064 & 0.1908 & 0.0058 & 0.0485 & 0.0004 & 0.5193 & 8.4 & 0.13 & 0.00 & 91.1 & 26.8 & 0.1 \\
\hline 4 & 356.3883 & 0.0735 & 24.0213 & 0.0259 & 0.3536 & 0.0060 & 0.5104 & 0.0056 & 0.0845 & 0.0004 & 1.1776 & 19.0 & 0.16 & 0.00 & 93.0 & 26.8 & 0.1 \\
\hline & & & & & & CB05; ar & bhibole; & ח & $=0.000001$ & & & & & & & & \\
\hline 0.5 & 0.0000 & 0.0124 & 0.0000 & 0.0164 & 0.0000 & 0.0060 & 0.0000 & 0.0057 & 0.0000 & 0.0001 & 0.0000 & 0.0 & 1.52 & 0.56 & 113.9 & 2.2 & 0.9 \\
\hline 1 & 15.3132 & 0.0130 & 0.2385 & 0.0152 & 0.0035 & 0.0060 & 0.0139 & 0.0059 & 0.0383 & 0.0003 & 0.0117 & 3.0 & 0.33 & 0.14 & 26.1 & 32.5 & 2.1 \\
\hline 1.5 & 10.9507 & 0.0138 & 0.4523 & 0.0152 & 0.0000 & 0.0064 & 0.6795 & 0.0059 & 0.0139 & 0.0002 & 0.0222 & 5.6 & 8.50 & 0.28 & 63.8 & 30.1 & 1.0 \\
\hline 1.7 & 10.4537 & 0.0125 & 0.5446 & 0.0158 & 0.0000 & 0.0059 & 1.4965 & 0.0061 & 0.0080 & 0.0001 & 0.0267 & 6.8 & 15.55 & 0.43 & 80.3 & 30.1 & 0.8 \\
\hline 1.9 & 15.2732 & 0.0146 & 0.9349 & 0.0164 & 0.0000 & 0.0059 & 2.7365 & 0.0064 & 0.0097 & 0.0001 & 0.0458 & 11.6 & 16.57 & 0.28 & 84.9 & 27.1 & 0.5 \\
\hline 2.1 & 20.6066 & 0.0138 & 1.1153 & 0.0171 & 0.0040 & 0.0063 & 3.2045 & 0.0064 & 0.0170 & 0.0002 & 0.0547 & 13.9 & 16.27 & 0.24 & 78.8 & 28.4 & 0.4 \\
\hline 2.3 & 35.3458 & 0.0163 & 2.1400 & 0.0165 & 0.0322 & 0.0060 & 6.0048 & 0.0075 & 0.0211 & 0.0002 & 0.1049 & 26.6 & 15.89 & 0.12 & 85.8 & 27.7 & 0.2 \\
\hline 2.5 & 25.2461 & 0.0146 & 1.6229 & 0.0148 & 0.0056 & 0.0061 & 4.9459 & 0.0071 & 0.0102 & 0.0001 & 0.0796 & 20.2 & 17.26 & 0.15 & 92.0 & 28.0 & 0.3 \\
\hline 2.7 & 3.2705 & 0.0127 & 0.1874 & 0.0158 & 0.0000 & 0.0061 & 0.6486 & 0.0062 & 0.0013 & 0.0001 & 0.0092 & 2.3 & 19.61 & 1.58 & 92.4 & 31.5 & 2.5 \\
\hline 3.2 & 7.7477 & 0.0120 & 0.4721 & 0.0158 & 0.0000 & 0.0060 & 1.2732 & 0.0060 & 0.0046 & 0.0001 & 0.0231 & 5.9 & 15.29 & 0.49 & 86.0 & 27.5 & 0.9 \\
\hline 3.5 & 1.8850 & 0.0116 & 0.1048 & 0.0150 & 0.0000 & 0.0063 & 0.3157 & 0.0061 & 0.0009 & 0.0001 & 0.0051 & 1.3 & 17.08 & 2.35 & 89.6 & 31.4 & 4.3 \\
\hline 4 & 1.5128 & 0.0121 & 0.0846 & 0.0146 & 0.0000 & 0.0058 & 0.3222 & & 0.0009 & 0.0001 & 0.0041 & 1.1 & 21.61 & 3.56 & 86.5 & 30.2 & 5.0 \\
\hline 5 & 2.8037 & 0.0122 & 0.1446 & 0.0158 & 0.0000 & 0.0062 & 0.6218 & 0.0058 & 0.0013 & 0.0001 & 0.0071 & 1.8 & 24.39 & 2.54 & 91.1 & 34.5 & 3.6 \\
\hline & & & & & & מחתח & & 20085 & 000001 & & & & & & & & \\
\hline 0.7 & 136.6897 & 350 & 4417 & 0.0155 & 0.1020 & 0.0059 & 0.0000 & 0.0059 & 0.4340 & & 0.0707 & 2.0 & 0.00 & 0.03 & 6.2 & 11.4 & 1.1 \\
\hline 0.9 & 45.4422 & 0.0189 & 2.4909 & 0.0142 & 0.0403 & 0.0062 & 0.0027 & 0.0057 & 0.0877 & 0.0004 & 0.1221 & 3.4 & 0.01 & 0.02 & 43.0 & 15.3 & 0.2 \\
\hline 1 & 38.9876 & 0.0163 & 2.4554 & 0.0156 & 0.0472 & 0.0061 & 0.0000 & 0.0061 & 0.0228 & 0.0002 & 0.1204 & 3.4 & 0.00 & 0.02 & 82.7 & 25.5 & 0.2 \\
\hline 1.1 & 43.6494 & 0.0180 & 2.8324 & 0.0156 & 0.0415 & 0.0062 & 0.0034 & 0.0063 & 0.0160 & 0.0002 & 0.1389 & 3.9 & 0.01 & 0.02 & 89.2 & 26.7 & 0.2 \\
\hline 1.2 & & & & & & & & & & & 681 & 4.7 & 0.00 & 0.01 & 92.1 & 27.2 & 0.1 \\
\hline 1.3 & 63.7147 & 0.0207 & 4.1999 & 0.0144 & 0.0495 & 0.0060 & 0.0000 & 0.0058 & 0.0145 & 0.0002 & 0.2059 & 5.8 & 0.00 & 0.01 & 93.3 & 27.5 & 0.1 \\
\hline 1.4 & 71.2201 & 0.0217 & 4.7265 & 0.0145 & 0.0523 & 0.0062 & 0.0116 & 0.0059 & 0.0125 & 0.0002 & 0.2317 & 6.5 & 0.02 & 0.01 & 94.8 & 27.7 & 0.1 \\
\hline 1.5 & 84.6582 & 0.0254 & 5.5686 & 0.0161 & 0.0527 & 0.0062 & 0.0000 & 0.0061 & 0.0135 & 0.0002 & 0.2730 & 7.7 & 0.00 & 0.01 & 95.3 & 28.1 & 0.1 \\
\hline 1.6 & 82.2364 & 0.0245 & 5.4601 & 0.0154 & 0.0953 & 0.0062 & 0.0000 & 0.0057 & 0.0132 & 0.0002 & 0.2677 & 7.5 & 0.00 & 0.01 & 95.2 & 27.9 & 0.1 \\
\hline 1.7 & 75.1684 & 0.0235 & 4.9952 & 0.0138 & 0.0496 & 0.0061 & 0.0000 & 0.0062 & 0.0120 & 0.0002 & 0.2449 & 6.9 & 0.00 & 0.01 & 95.3 & 27.8 & 0.1 \\
\hline 2 & 169.2794 & 0.0438 & 11.2702 & 0.0185 & 0.1507 & 0.0067 & 0.0232 & 0.0058 & 0.0280 & 0.0003 & 0.5525 & 15.6 & 0.02 & 0.00 & 95.1 & 27.7 & 0.1 \\
\hline 2.2 & 123.5714 & 0.0302 & 8.4225 & 0.0162 & & 0.0064 & 0.0670 & & & 0.0002 & .4129 & 11.6 & 0.06 & 0.01 & 96.3 & 27.4 & 0.1 \\
\hline 2.4 & 115.6774 & 0.0292 & 8.0203 & 0.0174 & 0.0967 & 0.0063 & 0.1364 & 0.0062 & 0.0097 & 0.0002 & 0.3932 & 11.1 & 0.13 & 0.01 & 97.5 & 27.3 & 0.1 \\
\hline 2.6 & 52.1966 & 0.0189 & 3.6188 & 0.0150 & 0.0372 & 0.0063 & 0.0977 & 0.0063 & 0.0052 & 0.0001 & 0.1774 & 5.0 & 0.20 & 0.01 & 97.1 & 27.2 & 0.1 \\
\hline 2.8 & 34.9834 & 0.0163 & 2.3867 & 0.0149 & 0.0378 & 0.0066 & 0.0755 & 0.0061 & 0.0034 & 0.0001 & 0.1170 & 3.3 & 0.24 & 0.02 & 97.2 & 27.7 & 0.2 \\
\hline 3 & 16.7162 & 0.0138 & 1.1314 & 0.0141 & 0.0009 & 0.0064 & 0.0063 & 0.0059 & 0.0020 & 0.0001 & 0.0555 & 1.6 & 0.04 & 0.04 & 96.4 & 27.7 & 0.3 \\
\hline & & & & & 11SC & & ock chi & $\mathrm{J}=0.0$ & \pm \pm 0.0000 & & & & & & & & \\
\hline 0.1 & 26.7409 & 403 & 2.5337 & 0.0079 & 0.0463 & 0.0010 & 3.3390 & 0.0157 & 0.0754 & 0.0008 & 0.0561 & 0.7 & 0.01 & 0.02 & 17.5 & 21.8 & 1.1 \\
\hline 0.3 & 33.0594 & 0.0582 & 9.9924 & 0.0131 & 0.1398 & 0.0016 & 4.0168 & 0.0293 & 0.0747 & 0.0008 & 0.2211 & 2.9 & 0.01 & 0.01 & 36.2 & 14.1 & 0.3 \\
\hline 0.5 & 39.1656 & 0.0514 & 22.0672 & 0.0360 & 0.2954 & 0.0023 & 36.4758 & 0.0572 & 0.0497 & 0.0008 & 0.4881 & 6.4 & 0.01 & 0.01 & 69.1 & 14.5 & 0.1 \\
\hline 0.7 & 38.8603 & 0.0464 & 27.2483 & 0.0580 & 0.3326 & 0.0022 & 34.6457 & 0.0825 & 0.0322 & 0.0007 & 0.6030 & 7.9 & 0.01 & 0.01 & 81.8 & 13.8 & 0.1 \\
\hline 0.9 & 37.4687 & 0.0504 & 27.4174 & 0.0350 & 0.3378 & 0.0020 & 37.7136 & 0.0643 & 0.0275 & 0.0007 & 0.6067 & 7.9 & 0.01 & 0.01 & 85.5 & 13.8 & 0.1 \\
\hline 1.1 & 55.9389 & 0.0484 & 43.3737 & 0.0500 & 0.5479 & 0.0025 & 74.1922 & 0.0827 & 0.0374 & 0.0008 & 0.9598 & 12.5 & 0.01 & 0.01 & 89.7 & 13.6 & 0.1 \\
\hline 1.3 & 50.7195 & 0.0583 & 40.9589 & 0.0620 & 0.5181 & 0.0021 & 66.1568 & 0.1195 & 0.0271 & 0.0008 & 0.9066 & 11.8 & 0.01 & 0.01 & 93.5 & 13.7 & 0.1 \\
\hline 1.5 & 44.1940 & 0.0445 & 35.8754 & 0.0530 & 0.4515 & 0.0022 & 54.6852 & 0.0736 & 0.0243 & 0.0007 & 0.7939 & 10.4 & 0.01 & 0.01 & 92.5 & 13.5 & 0.1 \\
\hline 1.7 & 39.7320 & 0.0405 & 32.4070 & 0.0671 & 0.4116 & 0.0027 & 48.6040 & 0.0599 & 0.0193 & 0.0007 & 0.7171 & 9.4 & 0.01 & 0.01 & 94.3 & 13.6 & 0.1 \\
\hline 1.9 & 32.6682 & 0.0395 & 25.6023 & 0.0630 & 0.3316 & 0.0024 & 42.6266 & 0.0876 & 0.0151 & 0.0007 & 0.5665 & 7.4 & 0.01 & 0.01 & 95.6 & 14.4 & 0.1 \\
\hline 2.2 & 24.4054 & 0.0375 & 19.5279 & 0.0420 & 0.2594 & 0.0023 & 35.0510 & 0.0923 & 0.0143 & 0.0007 & 0.4321 & 5.6 & 0.01 & 0.01 & 92.8 & 13.7 & 0.1 \\
\hline 2.5 & 21.6011 & 0.0425 & 17.1491 & 0.0250 & 0.2257 & 0.0018 & 43.1225 & 0.0924 & 0.0160 & 0.0007 & 0.3794 & 5.0 & 0.01 & 0.01 & 92.3 & 13.7 & 0.2 \\
\hline 2.8 & 15.7632 & 0.0145 & 12.2418 & 0.0220 & 0.1721 & 0.0020 & 38.1060 & 0.0694 & 0.0150 & 0.0007 & 0.2708 & 3.5 & 0.02 & 0.01 & 89.0 & 13.5 & 0.2 \\
\hline 3.1 & 11.1034 & 0.0229 & 8.4761 & 0.0094 & 0.1226 & 0.0016 & 31.0009 & 0.0833 & 0.0125 & 0.0007 & 0.1875 & 2.4 & 0.02 & 0.01 & 86.6 & 13.4 & 0.3 \\
\hline 3.5 & 9.4148 & 0.0145 & 7.0967 & 0.0099 & 0.1014 & 0.0016 & 35.2859 & 0.1111 & 0.0132 & 0.0007 & 0.1570 & 2.1 & 0.03 & 0.01 & 85.3 & 13.4 & 0.3 \\
\hline 4 & 7.4505 & 0.0336 & 5.5201 & 0.0082 & 0.0772 & 0.0012 & 31.0930 & 0.0927 & 0.0102 & 0.0007 & 0.1221 & 1.6 & 0.04 & 0.01 & 89.2 & 14.2 & 0.5 \\
\hline 4.5 & 5.7175 & 0.0118 & 4.3620 & 0.0088 & 0.0622 & 0.0013 & 26.9858 & 0.0465 & 0.0088 & 0.0007 & 0.0965 & 1.3 & 0.03 & 0.01 & 88.3 & 13.7 & 0.5 \\
\hline
\end{tabular}


Appendix Table 1-1. Combined ${ }^{40} \mathrm{Ar} /{ }^{39} \mathrm{Ar}$ data for Grosvenor Hills Volcanics and Nogales Formation. (Click here to access digital file.) -Continued

\begin{tabular}{|c|c|c|c|c|c|c|c|c|c|c|c|c|c|c|c|c|c|}
\hline \multirow{3}{*}{$\begin{array}{l}\text { Laser } \\
\text { power } \\
\text { watts }\end{array}$} & \multicolumn{10}{|c|}{ Relative isotopic abundances } & \multicolumn{7}{|c|}{ Derived results } \\
\hline & \multicolumn{2}{|c|}{$\begin{array}{l}{ }^{40} \mathrm{Ar} \\
\pm 1 \sigma\end{array}$} & \multicolumn{2}{|c|}{$\begin{array}{l}{ }^{39} \mathbf{A r} \\
\pm 1 \sigma\end{array}$} & \multicolumn{2}{|c|}{$\begin{array}{l}{ }^{38} \mathrm{Ar} \\
\pm 1 \sigma\end{array}$} & \multicolumn{2}{|c|}{$\begin{array}{l}{ }^{37} \mathrm{Ar} \\
\pm 1 \sigma\end{array}$} & \multicolumn{2}{|c|}{$\begin{array}{l}{ }^{36} \mathrm{Ar} \\
\pm 1 \sigma\end{array}$} & $\begin{array}{l}{ }^{39} \mathrm{Ar} \mathrm{Mol} \\
\infty \mathbf{1 0}^{-14}\end{array}$ & $\begin{array}{l}{ }^{39} \mathrm{Ar} \% \\
\text { of total }\end{array}$ & \multicolumn{2}{|c|}{$\begin{array}{l}\mathrm{Ca} / \mathrm{K} \\
\pm 1 \sigma\end{array}$} & \multirow[t]{2}{*}{$\%^{40} \mathrm{Ar}$} & \multicolumn{2}{|c|}{$\begin{array}{c}\text { Age (Ma) } \\
\quad \pm 1 \sigma\end{array}$} \\
\hline & \multicolumn{16}{|c|}{ 11SCB06; whole rock chip; J=0.006560 \pm 0.000012} & \\
\hline 5 & 6.0280 & 0.0219 & 4.3238 & 0.0075 & 0.0621 & 0.0012 & 35.7661 & 0.0558 & 0.0063 & 0.0007 & 0.0957 & 1.2 & 0.04 & 0.01 & 111.4 & 18.4 & 0.6 \\
\hline 0.5 & 33.8749 & 0.0713 & 15.2345 & 0.0191 & 0.1993 & 0.0016 & 21.1116 & 0.0524 & 0.0521 & 0.0008 & 0.3370 & 3.3 & 0.01 & 0.01 & 59.0 & 15.5 & 0.2 \\
\hline 0.7 & 49.3235 & 0.0465 & 33.2874 & 0.0661 & 0.4038 & 0.0025 & 41.7231 & 0.0762 & 0.0449 & 0.0008 & 0.7364 & 7.2 & 0.01 & 0.01 & 79.1 & 13.8 & 0.1 \\
\hline 0.9 & 55.7515 & 0.0594 & 43.0273 & 0.0661 & 0.5356 & 0.0023 & 57.8770 & 0.1334 & 0.0324 & 0.0008 & 0.9519 & 9.3 & 0.01 & 0.01 & 90.2 & 13.8 & 0.1 \\
\hline 1.1 & 69.8337 & 0.0663 & 55.6585 & 0.0961 & 0.6951 & 0.0025 & 82.4812 & 0.1526 & 0.0392 & 0.0008 & 1.2318 & 12.1 & 0.01 & 0.01 & 91.8 & 13.6 & 0.1 \\
\hline 1.3 & 77.4193 & 0.0574 & 62.9580 & 0.0771 & 0.7959 & 0.0031 & 109.2696 & 0.1957 & 0.0426 & 0.0009 & 1.3934 & 13.7 & 0.01 & 0.01 & 93.7 & 13.6 & 0.1 \\
\hline 1.5 & 63.7337 & 0.0683 & 51.3540 & 0.0761 & 0.6444 & 0.0031 & 110.8370 & 0.2484 & .0431 & 0.0011 & 1.1365 & 11.2 & 0.01 & 0.01 & 92.4 & 13.5 & 0.1 \\
\hline 1.7 & 50.3109 & 0.0793 & 40.2054 & 0.0560 & 0.5016 & 0.0024 & 94.0554 & 0.1435 & 0.0382 & 0.0008 & 0.8899 & 8.7 & 0.01 & 0.01 & 90.8 & 13.4 & 0.1 \\
\hline 1.9 & 44.1077 & 0.0484 & 35.5962 & 0.0671 & 0.4457 & 0.0025 & 73.7883 & 0.0910 & 0.0340 & 0.0008 & 0.7878 & 7.7 & 0.01 & 0.01 & 89.1 & 13.0 & 0.1 \\
\hline 2.2 & 49.5110 & 0.0633 & 39.2241 & 0.2401 & 0.5239 & 0.0027 & 78.1136 & 0.0959 & .0378 & 0.0008 & 0.8680 & 8.5 & 0.02 & 0.01 & 88.6 & 13.2 & 0.1 \\
\hline 2.5 & 37.9920 & 0.0425 & 29.9134 & 0.0901 & 0.4016 & 0.0028 & 86.5946 & 0.1103 & 0.0343 & 0.0008 & 0.6619 & 6.5 & 0.02 & 0.01 & 89.5 & 13.4 & 0.1 \\
\hline 2.8 & 27.3964 & 0.0336 & 21.1050 & 0.0370 & 0.3082 & 0.0022 & 106.6702 & 0.2352 & 0.0423 & 0.0008 & 0.4669 & 4.6 & 0.03 & 0.01 & 82.0 & 12.6 & 0.2 \\
\hline 3.1 & 15.0828 & 0.0336 & 11.7838 & 0.0300 & 0.1690 & 0.0015 & 66.1091 & 0.1682 & 0.0237 & 0.0007 & 0.2607 & 2.6 & 0.04 & 0.01 & 84.7 & 12.8 & 0.2 \\
\hline 3.5 & 7.9149 & 0.0229 & 6.1416 & 0.0111 & 0.0887 & 0.0014 & 30.8003 & 0.0482 & .0125 & 0.0007 & 0.1358 & 1.3 & 0.02 & 0.01 & 81.0 & 12.3 & 0.4 \\
\hline 4 & 6.3710 & 0.0201 & 4.8789 & 0.0070 & 0.0780 & 0.0013 & 28.1854 & 0.0531 & 0.0130 & 0.0007 & 0.1079 & 1.1 & 0.03 & 0.02 & 71.0 & 11.0 & 0.5 \\
\hline 4.5 & 6.6559 & 0.0201 & 4.9501 & 0.0111 & 0.0735 & 0.0013 & 40.7765 & 0.1975 & 0.0167 & 0.0007 & 0.1095 & 1.1 & 0.09 & 0.01 & 69.2 & 11.0 & 0.5 \\
\hline 5 & 4509 & 201 & 4.9121 & 0.0085 & 0.0790 & 0.0012 & 57.6757 & 0.0772 & 0.0233 & 0.0008 & 0.1087 & 1.1 & 0.05 & 0.02 & 62.7 & 11.3 & 0.6 \\
\hline \multicolumn{18}{|c|}{ 11SCB07; whole rock; J=0.006560 \pm 0.000012} \\
\hline 0.1 & 7125 & 0220 & 1379 & 0080 & .0425 & 0.0011 & 1.4352 & 0.0130 & 0.0245 & 0.00 & 473 & 0.4 & 0.01 & 0.02 & 26.6 & 14.2 & 1.2 \\
\hline 0.3 & 31.1760 & 0.0703 & 13.5355 & 0.0290 & 0.2389 & 0.0019 & 12.9154 & 0.0364 & 0.0628 & 0.0008 & 0.2995 & 2.5 & 0.01 & 0.02 & 43.4 & 11.8 & 0.2 \\
\hline 0.5 & 53.9568 & 0.2301 & 38.3681 & 0.0390 & 0.6317 & 0.0030 & 22.8107 & 0.0451 & 0.0645 & 0.0008 & 0.8491 & 7.1 & 0.00 & 0.02 & 67.7 & 11.2 & 0.1 \\
\hline 0.7 & 89.4397 & 0.0813 & 71.1962 & 0.0711 & 1.1088 & 0.0035 & 41.4883 & 0.0872 & 0.0793 & 0.0008 & 1.5757 & 13.2 & 0.00 & 0.02 & 77.1 & 11.4 & 0.1 \\
\hline 0.9 & 101.5562 & 0.0922 & 77.2487 & 0.0721 & 1.1618 & 0.0048 & 48.7935 & 0.1019 & 0.0973 & 0.0009 & 1.7095 & 14.3 & 0.00 & 0.02 & 75.1 & 11.7 & 0.1 \\
\hline 1.1 & 97.8601 & 0.0992 & 69.5568 & 0.0651 & 1.0311 & 0.0041 & 62.9879 & 0.1262 & 0.1145 & 0.0009 & 1.5393 & 12.9 & 0.00 & 0.01 & 70.0 & 11.6 & 0.1 \\
\hline 1.3 & 88.3604 & 0.0932 & 59.7004 & 0.0931 & 0.8630 & 0.0037 & 73.8273 & 0.1117 & 0.1149 & 0.0011 & 1.3210 & 11.0 & 0.01 & 0.01 & 67.5 & 11.8 & 0.1 \\
\hline 1.5 & 63.3343 & 0.0673 & 42.1354 & 0.0711 & 0.5908 & 0.0027 & 64.6049 & 0.1459 & 0.0897 & 0.0009 & 0.9324 & 7.8 & 0.01 & 0.01 & 65.4 & 11.6 & 0.1 \\
\hline 1.7 & 45.0243 & 0.0524 & 31.0115 & 0.0540 & 0.4352 & 0.0025 & 55.3136 & 0.0731 & 0.0629 & 0.0008 & 0.6861 & 5.7 & 0.01 & 0.01 & 67.5 & 11.6 & 0.1 \\
\hline 1.9 & 32.0722 & 0.0614 & 22.9950 & 0.0400 & 0.3273 & 0.0024 & 46.5467 & 0.0780 & 0.0409 & 0.0007 & 0.5088 & 4.3 & 0.01 & 0.01 & 72.6 & 12.0 & 0.1 \\
\hline 2.2 & 23.6732 & 0.0415 & 17.9105 & 0.0250 & 0.2600 & 0.0022 & 42.9144 & 0.0732 & 0.0315 & 0.0007 & 0.3963 & 3.3 & 0.01 & 0.01 & 73.5 & 11.5 & 0.1 \\
\hline 2.5 & 19.1620 & 0.0220 & 13.8255 & 0.0230 & 0.1996 & 0.0015 & 43.7427 & 0.0781 & 0.0274 & 0.0007 & 0.3059 & 2.6 & 0.02 & 0.01 & 74.0 & 12.1 & 0.2 \\
\hline 2.8 & 23.4549 & 0.0435 & 16.9311 & 0.0220 & 0.2393 & 0.0024 & 72.9093 & 0.1319 & 0.0440 & 0.0008 & 0.3746 & 3.1 & 0.02 & 0.01 & 66.6 & 10.9 & 0.2 \\
\hline 3.5 & 40.0035 & 0.0390 & 25.6920 & 0.0581 & 0.3708 & 0.0023 & 141.0033 & 0.2670 & 0.0889 & 0.0009 & 0.5685 & 4.8 & 0.03 & 0.01 & 59.3 & 10.9 & 0.2 \\
\hline 4 & 41.6872 & 0.0448 & 25.7361 & 0.0380 & 0.3730 & 0.0023 & 151.1846 & 0.3959 & 0.0927 & 0.0009 & 0.5694 & 4.8 & 0.04 & 0.01 & 60.0 & 11.5 & 0.2 \\
\hline 4.5 & 13.1816 & 0.0303 & 7.3429 & 0.0121 & 0.1056 & 0.0014 & 53.0925 & 0.0895 & 0.0349 & 0.0007 & 0.1625 & 1.4 & 0.03 & 0.01 & 50.3 & 10.7 & 0.4 \\
\hline 5 & 8.9796 & 0.0227 & 5.2498 & 0.0083 & 0.0802 & 0.0016 & 40.4447 & 0.0747 & 0.0227 & 0.0008 & 0.1162 & 1.0 & 0.04 & 0.02 & 57.4 & 11.6 & 0.6 \\
\hline
\end{tabular}

Note: For this study ages were calculated with decay constants in Steiger and Jaeger (1977), $\mathrm{a}^{40} \mathrm{Ar} /{ }^{36} \mathrm{Ar}$ value of atmosphere $=298.56 \pm 0.31(\mathrm{Lee}$ and others, 2006) and an age of $28.02 \pm 0.16$ for Fish Canyon sanidine (Renne and others, 1998). Argon isotope data acquired by simultaneous collection of all masses on Faraday collectors (masses 40-37) and ion counter (mass 36) with a Thermo Scientific ARGUSVI mass spectrometer (samples with a 12SCB-prefix), and by peak hopping with a single electron multiplier in analog mode using a Mass Analyser Products 215-50 mass spectrometer (samples with 11SCB prefix). All data corrected for blanks, radioactive decay, nucleogenic interferences, mass discrimination, and detector intercalibration.

Lee, J.Y., Marti, K., Severinghaus, J.P., Kawamura, K., Yoo, H.S., Lee, J.B., and Kim, J.S., 2006, A redetermination of the isotopic abundances of atmospheric Ar: Geochim. Cosmochim, Acta70, p. 4507-4512.

Renne, P.R., Swisher, C.C., Deino, A.L., Karner, D.B., Owens, T.L., and DePaolo, D.J., 1998, Intercalibration of standards, absolute ages and uncertainties in $\mathrm{Ar}^{40} / \mathrm{Ar}^{39}$ dating: Chemical Geology 145(1-2), p. 117-152. doi: 10.1016/S0009-2541(97)00159-9.

Steiger, R.H., and Jager, E., 1977, Subcommission on geochronology - Convention on the use of decay constants in geo- and cosmochronology: Earth and Planetary Science Letters 36(3), p. 359-362. 
Publishing support provided by:

Denver Publishing Service Center, Denver, Colorado

For more information concerning this publication, contact:

Center Director, USGS Geology and Environmental Change Science Center Box 25046, Mail Stop 980

Denver, C0 80225

(303) 236-5344

Or visit the Geology and Environmental Change Science Center at: http://gec.cr.usgs.gov/

This publication is available online at: http://dx.doi.org/10.3133/sim3354 


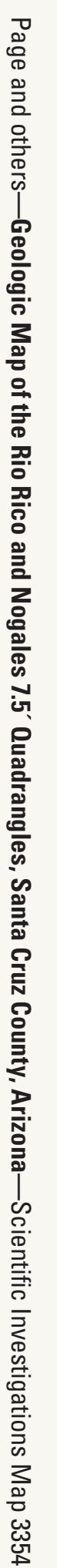

